\title{
The EU REIT and the internal market for real estate
}

Citation for published version (APA):

Eichholtz, P. M. A., \& Kok, N. (2007). The EU REIT and the internal market for real estate. European Landowners' Organization, the European Property Federation, the Royal Institution of Chartered Surveyors, The European Group of Valuers' Associations, and the Urban Land Institute Europe. https://doi.org/10.2139/SSRN.1081198

Document status and date:

Published: 01/01/2007

DOI:

10.2139/SSRN.1081198

Document Version:

Publisher's PDF, also known as Version of record

\section{Please check the document version of this publication:}

- A submitted manuscript is the version of the article upon submission and before peer-review. There can be important differences between the submitted version and the official published version of record.

People interested in the research are advised to contact the author for the final version of the publication, or visit the DOI to the publisher's website.

- The final author version and the galley proof are versions of the publication after peer review.

- The final published version features the final layout of the paper including the volume, issue and page numbers.

Link to publication

\footnotetext{
General rights rights.

- You may freely distribute the URL identifying the publication in the public portal. please follow below link for the End User Agreement:

www.umlib.nl/taverne-license

Take down policy

If you believe that this document breaches copyright please contact us at:

repository@maastrichtuniversity.nl

providing details and we will investigate your claim.
}

Copyright and moral rights for the publications made accessible in the public portal are retained by the authors and/or other copyright owners and it is a condition of accessing publications that users recognise and abide by the legal requirements associated with these

- Users may download and print one copy of any publication from the public portal for the purpose of private study or research.

- You may not further distribute the material or use it for any profit-making activity or commercial gain

If the publication is distributed under the terms of Article $25 \mathrm{fa}$ of the Dutch Copyright Act, indicated by the "Taverne" license above, 


\section{The EU REIT and the Internal Market for Real Estate}

A research report for the European Landowners' Organization, the European Property Federation, the Royal Institution of Chartered Surveyors, The European Group of Valuers'Associations, and the Urban Land Institute Europe
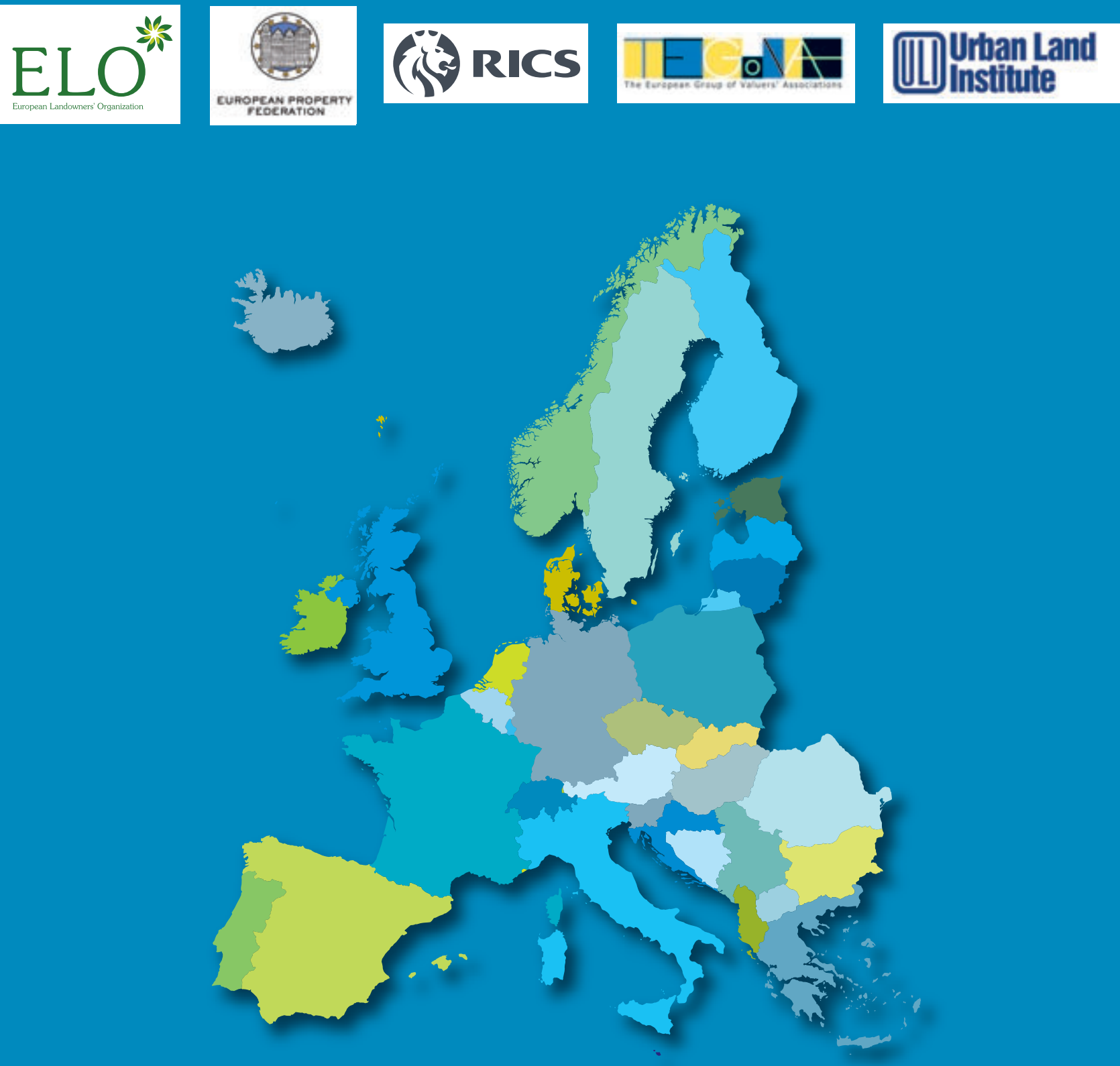

Prof.dr Piet Eichholtz / Drs Nils Kok

Maastricht University 

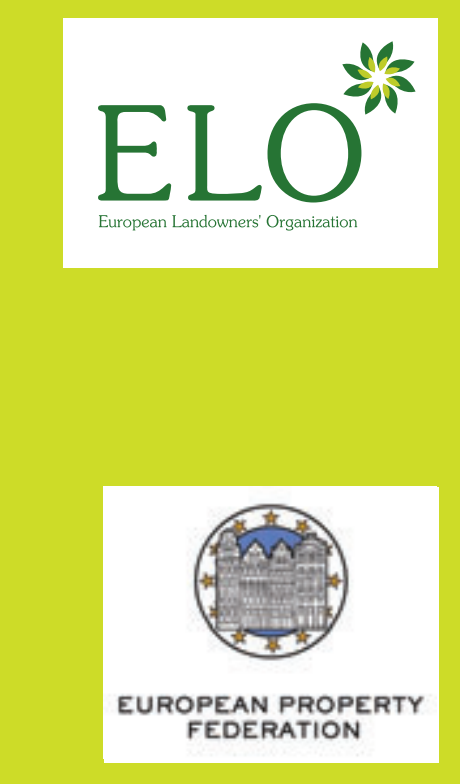

(1) RICS
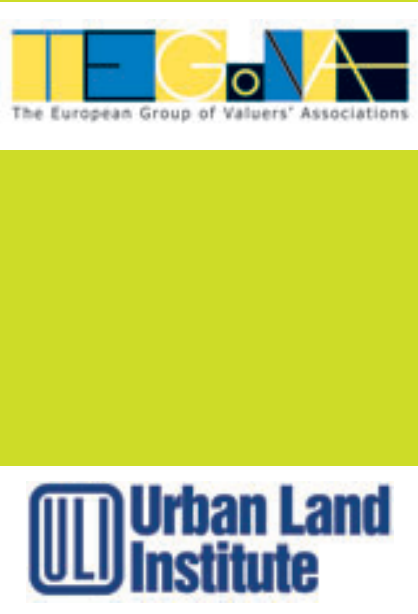

\section{EUROPEAN LANDOWNERS' ORGANIZATION (ELO)}

Rue de Trêves, 67

B - 1040 Bruxelles

Tel. : +32 (0) 22343000

Fax : +32 (0) 22343009

elo@elo.org

www.elo.org

\section{EUROPEAN PROPERTY FEDERATION (EPF)}

Place de la Vieille Halle aux Blés, 28

B - 1000 Bruxelles

Tel. : +3225144229

Fax : +3225116721

info@epf-fepi.com

www.epf-fepi.com

\section{ROYAL INSTITUTION OF CHARTERED SURVEYORS (RICS)}

Rue Ducale 67 Hertogstraat

1000 Brussels

Belgium

Tel. : +32 27331019

Fax : +32 27429748

PublicAffairsBrussels@rics.org

www.rics.org

\section{THE EUROPEAN GROUP OF VALUERS' ASSOCIATIONS (TEGOVA)}

Place de la Vieille Halle aux Blés 28

B - 1000 Bruxelles

Tel. : +32 25033234

Fax : +32 25033232

tegova@skynet.be

www.tegova.org

\section{URBAN LAND INSTITUTE EUROPE (ULI EUROPE)}

29 Gloucester Place

London W1U 8HX

United Kingdom

Tel. : +44 (0)20 74879570

Fax : +44 (0)20 74862359

london@uli.org

www.europe.uli.org 


\section{Preface}

The property industry is like the European Union: It has transformed itself in less than a generation and become much better equipped to meet the needs of European citizens. Yet at the same time, the job is not yet done, the transformation far from complete. More effort is needed for things to work really well and be seen to work well.

The property industry is one of the bedrocks of Europe's wellbeing and competitiveness, providing the affordable housing and sophisticated infrastructure needed by citizens, services and industry. The European knowledge-based economy needs a property industry that competes in providing this investment everywhere in Europe and not just in the prime market segments, and property companies need European scale to develop their increasingly specialised products.

A specific regime has played a key role in the modernisation and enhancement of property investment: the Real Estate Investment Trust, or REIT, an investment vehicle that puts shareholders in property companies on a level playing field with investors who own property portfolios outright.

Governments and markets favour REITs because they enable industrial and service companies to sell off their corporate real estate, leaving it in the hands of property professionals and freeing up capital for core business, and because they enable small investors to safely invest in property, enjoying the diversification benefits this asset class has to offer and its qualities as a protection against inflation.

And yet there is no EU Internal Market for REITs. Investors have long been conscious of the problems raised by the lack of an EU REIT structure, but the Maastricht University report for the first time sheds light on the scale of the challenge:

- the need to address increasing distortions of competition as national REITs multiply

- the opportunity to buttress market safety and security. Simply by ensuring a properly functioning Internal Market for real estate investment, the EU can make a major contribution to the control and stabilisation of property markets

- the need to correct a situation where savers in small member states cannot access good quality property investment in other member states or even the prime property investments in their own countries

- the opportunity to reverse the current trend of initiators of property companies to resort to tax havens

- the chance to boost specialisation in cutting edge real estate and investment in social property that both require development on a European scale

The report goes farther, outlining a preferred structure for an EU REIT with no need for invasive tax harmonisation as no approximation of tax rates on shareholder dividends is required. 
Some readers may feel that it doesn't address all aspects; others may disagree with this or that option, but that would be missing the point, which is to kick-start a debate on REITs in the Internal Market and inspire the European authorities - national parliaments and governments, the European Parliament and the Commission - to focus on finding a solution so that we can all work to create, in Prof. Eichholtz's excellent words, the largest and most efficient property capital market in the world.

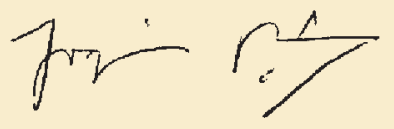

\section{Joaquim Ribeiro}

Chairman of the EU REIT Coalition 


\section{Executive Summary}

For pension funds and other investors, property is an important part of the portfolio, and many investors choose to build up their property exposure through publicly listed property companies. This market has grown substantially in the last two decades: from $€ 28$ billion in the early eighties to approximately $€ 1.2$ trillion in 2007.

To facilitate private savers and institutional investors, numerous countries have created special tax regimes for property companies, commonly called Real Estate Investment Trusts or REITs, so as to avoid double taxation, and to create a level playing field between different forms of real estate ownership. The goal of these regimes is to avoid taxing a rental income stream at the corporate level and again at the shareholder level. Thus, exemption from corporate tax for a property company puts the shareholder in such a property company in a comparable position with an investor who owns a property portfolio outright, since the rental stream for such an investor will only be taxed as income. In other words, corporate tax exemption creates a level playing field between the direct segment and the indirect segment of the property market. In this sense, such tax treatment of property companies is analogous to the corporate tax-exemption of mutual funds, for which a corporate tax levy would also entail double taxation.

Legislation regarding tax exemption of property companies is in flux: 13 out of the $27 \mathrm{EU}$ member states now have some kind of tax-transparent regime for property companies, of which most have been introduced in the last five years. Once introduced, these regimes tend to be reformed quite frequently. Moreover, the exact form of these regimes varies widely and seemingly arbitrarily - across countries, as Exhibit A shows. This holds especially with respect to operational restrictions, leverage restrictions, and the question whether stock market listing is mandatory. There seems to be no standard towards which the tax-transparent regimes evolve.

The strongly varying nature of property share regimes across the EU keeps the market for indirect property investments fragmented. This fragmentation hinders competition among property companies from different EU member states, and even more so between property companies and direct property investors, who face no double taxation to begin with, and are far less restricted in their operations and financing.

The fragmented market situation in the EU contrasts markedly with the situation in the United States, which has one and the same property share regime from coast to coast, enabling the development of a property share market that is now bigger than all of the EU's national property share markets combined.The market size created by this one legal regime enables property companies in the United States to harvest economies of scale and scope that are out of reach for their European counterparts. For example, U.S. property companies tend to be specialized in rather narrow product niches in the property market. The academic literature and empirical evidence presented in this report show that this focus generally improves the creation of shareholder value.

This market scale also facilitates access to the capital market for fast-evolving semi-government sectors like senior housing, healthcare, and correctional property. Besides that, the efficient tax regime for U.S. REITs provides fertile ground to spin off corporate real estate 
assets to institutional and private investors. It is very likely that specialized property investors add more value to their properties than do corporations and the government. Furthermore, these 'new' investment property categories will bring additional diversification benefits for investors.

Contrary to the developments in the United States, European property companies are mostly active in one member state only, and usually invest in a diversity of different property types, with office and retail property being the dominant investments. This precludes them from deep specialization and does not foster an innovative property capital market.

An additional disadvantage of the current institutional situation is that it makes international property diversification less efficient, especially for investors from member states who do not have a tax-transparent property company regime in place, and for those from smaller member states. This obstacle to diversification also hinders efficient allocation of capital across EU member states, especially to the new member states in Central Europe.

For private and institutional investors in the European Union to harvest the full potential of investments in the real estate market, it is important to have one uniform institutional setting for property companies, covering the European Union in its totality. To accomplish this uniform institutional setting, pan-EU regulation is of the utmost importance. Without such regulation, the EU's property share market will remain fragmented. This report shows that such a fragmented market leads to inefficient allocation of capital, which is particularly detrimental to small member states.

Introducing a pan-EU property company regime is not likely to produce significant tax losses for member states. Quite the contrary, the strongly increasing use of tax havens by listed property companies suggests that the market has already found ways to avoid double taxation. In the absence of a REIT regime, this development is likely to continue, and even expand. From a regulatory and supervisory point of view, however, the trend towards incorporation in tax havens is sub-optimal.

A pan-EU property company regime will support market safety and security. First, the introduction of a pan-EU property company regime would likely diminish the use of tax havens, which is beneficial for transparency. Second, although market integration has weakened the risk-spreading benefits of international diversification, the evidence in this report shows that the performances of different geographical property markets in Europe are still very dissimilar.This reduces risk, which is especially relevant in case of financial crises. Third, REITs frequently have to turn to the capital market, due to the obligatory distribution of earnings. Therefore, they are subject to regular scrutiny by external agents, which reduces the conflict of interest between managers and investors. Fourth, the evidence in this report shows that the introduction of a REIT-like structure lowers the use of debt in property companies. Especially in the light of the current crisis on the debt market, it is clear that lower debt levels increase financial security for investors.

The academic literature and additional empirical evidence presented in this report provide strong and fundamental arguments for the creation of an EU REIT. To offer guidance in creating such a structure, the report also presents the key components of a blueprint for a pan-EU regime for property companies, addressing governance issues, operational and financial requirements, and other structural issues. There is abundant academic literature 
regarding property companies, their operations, performance, and governance. This literature, combined with best practice experience that can be observed in the U.S. and European listed property markets, can lead the way towards an optimal regime for an EU REIT. Exhibit $B$ provides the key characteristics of a blueprint for such a regime.The EU REIT regime should leave maximum freedom for the management of property companies to engage in value creation for their shareholders. This would mean, among others, that restrictions on leverage and share ownership should be avoided, and that would also hold for mandatory listing of property company shares, and for portfolio diversification rules. Property development by EU REITs should be allowed, but taxed in such a way that a level playing field with pure property developers is maintained. Lastly, the EU REIT should have a closed-end structure and we strongly advise that internal management be allowed.

Creating an EU REIT along these lines would turn the current fragmented EU market for property companies into the largest and likely most efficient property share market in the world. Investors, small and large, private and institutional, would greatly benefit from that.

Exbibit $A$. The Dispersion of REIT-like Structures in EU Member States

\begin{tabular}{|c|c|c|c|c|c|c|}
\hline Country & $\begin{array}{c}\text { Tax } \\
\text { exempt }\end{array}$ & $\begin{array}{l}\text { Distribution } \\
\text { requirements }\end{array}$ & $\begin{array}{l}\text { Operational } \\
\text { Restrictions }\end{array}$ & $\begin{array}{c}\text { Leverage } \\
\text { Restrictions }\end{array}$ & $\begin{array}{l}\text { Shareholder } \\
\text { Requirements }\end{array}$ & $\begin{array}{l}\text { Withholding } \\
\text { Tax }\end{array}$ \\
\hline Austria & ++ & + & ++ & ++ & ++ & ++ \\
\hline Belgium & ++ & ++ & ++ & ++ & ++ & ++ \\
\hline Bulgaria & ++ & ++ & + & N/A & ++ & + \\
\hline France & + & ++ & ++ & 0 & ++ & ++ \\
\hline Germany & ++ & ++ & ++ & ++ & ++ & ++ \\
\hline Greece & ++ & 0 & ++ & ++ & ++ & ++ \\
\hline Italy & ++ & 0 & ++ & ++ & 0 & ++ \\
\hline Luxembourg & ++ & 0 & + & + & 0 & 0 \\
\hline Malta & + & 0 & 0 & ++ & + & ++ \\
\hline Netherlands & ++ & ++ & + & ++ & 0 & ++ \\
\hline Poland & ++ & 0 & ++ & ++ & 0 & ++ \\
\hline Spain & + & 0 & ++ & ++ & + & ++ \\
\hline UK & + & ++ & ++ & 0 & ++ & ++ \\
\hline
\end{tabular}

Note: This exhibit shows the characteristics of REIT-like structures in EU member states. A ' ++ ' indicates that the requirement or restriction is strong, a ' + ' indicates that it is moderate, whereas a ' 0 ' indicates that there are no or (almost) no requirements or restrictions. 
Restrictions and Requirements

Tax exempt

Payout requirement: $80 \%$ - 100\%

Internally managed

Operational restrictions

- development allowed, but taxed

- no diversification requirements

- no asset restrictions

No leverage restrictions

No mandatory listing

No ownership requirements

Withholding tax equal for domestic investors and those from other

EU member states

Closed-ended structure

\section{Motivation}

Avoids double taxation of rental income and creates level playing field with direct real estate ownership.

Guarantees ultimate tax payment and is effective government mechanism, mitigating agency problems.

Better governance and alignment of interests of managers and shareholders; better performance, more shareholder value.

Development can create shareholder value, but maintain level playing field with pure - taxed - developers.

Investors can diversify themselves and do not need extra protection.

Government should not interfere with investment strategy.

Restrictions put REITs at disadvantage to other property investors. Management should decide on optimal financing

Listing not always beneficial. Management should decide on optimal financing

Better for governance.

Creates level playing field for all EU investors.

Open-ended structure fundamentally unstable.

Closed-ended structure creates more shareholder value.

Note: this exhibit provides a blueprint of the EU REIT. Restrictions and requirements are based on the existing academic literature and empirical evidence presented in this report. 


\section{Contents}

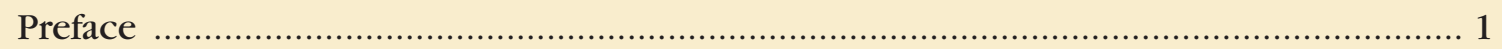

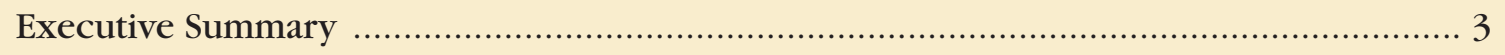

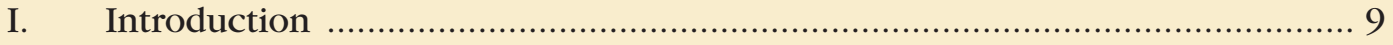

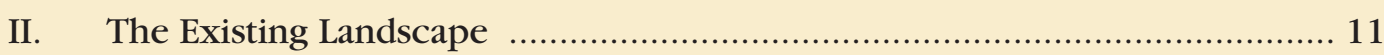

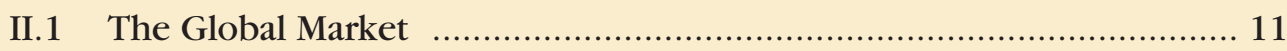

II.2 Tax-transparent Regimes in the EU ….............................................. 12

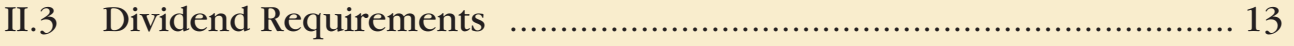

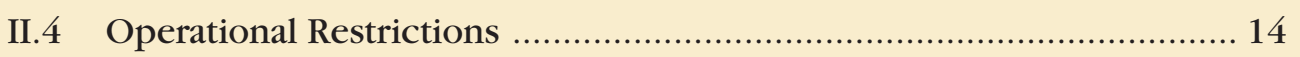

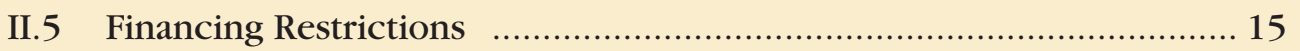

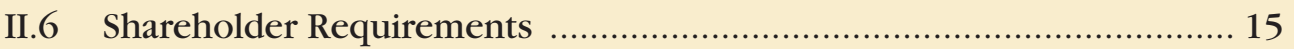

III. Problems with the Current Institutional Structure in the EU ....................... 17

III.1 Distorted Competition .................................................................. 18

III.2 Impediments to Specialization …………….................................. 19

III.3 Effects on Investment Performance ……….................................. 22

III.4 Disadvantages to Individual Member States .................................... 26

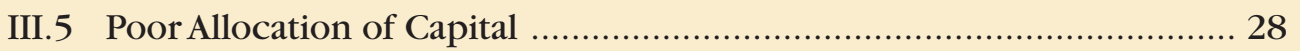

III.6 Market Safety and Security ……………...................................... 31

IV. Policy Options: Zero Is Not an Option ……............................................. 33

V. The Preferred Structure for the EU REIT …................................................. 37

V.1 Governance Issues and Additional Requirements …........................... 37

V.2 Open- versus Closed-Ended Structures ............................................. 43

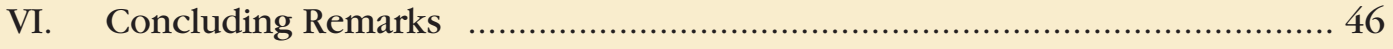

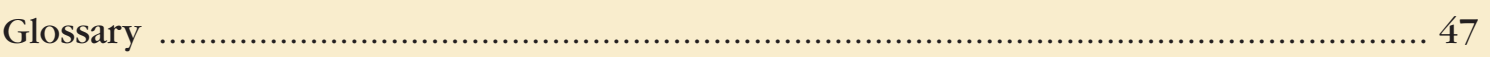

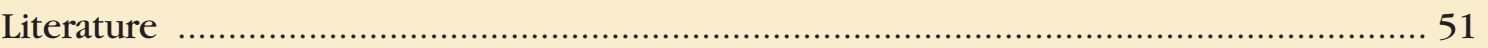

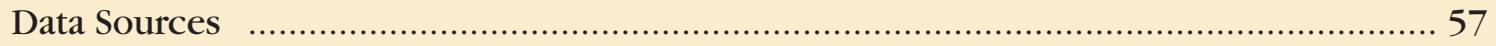




\section{Exhibits}

Exhibit A. The Dispersion of REIT-like Structures in EU Member States ….................... 5

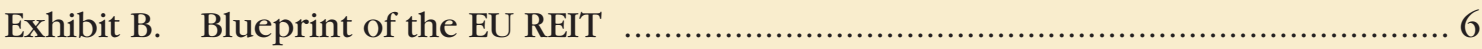

Exhibit 1. Growth of the Global Property Share Market …............................................ 58

Exhibit 2. Initial Public Offerings of Property Companies in Europe ……................... 59

Exhibit 3. Global Property Share Market: Country Information ................................... 60

Exhibit 4. Structures for Listed Property Companies in the EU ...................................... 61

Exhibit 5. Tax Treatment of Tax-transparent Property Companies in the EU .................. 62

Exhibit 6. Cash Flow Taxation of Property Investments in the EU ................................ 63

Exhibit 7. Distribution Requirements for Tax-transparent

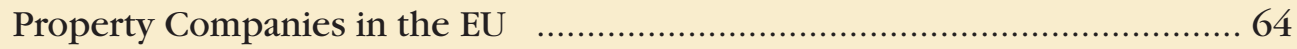

Exhibit 8. Operational Restrictions of Tax-transparent

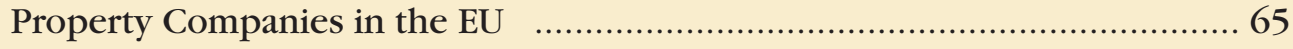

Exhibit 9. Leverage Restrictions for Tax-transparent

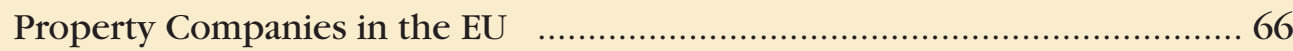

Exhibit 10. Shareholder Requirements for Tax-transparent

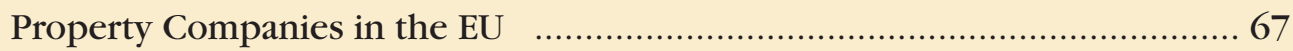

Exhibit 11. Withholding Tax Treatment of Tax-transparent

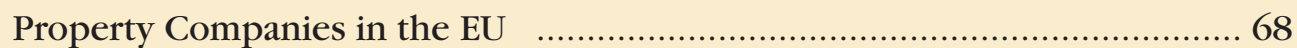

Exhibit 12. Diversification of European Property Companies ........................................69

Exhibit 13. Investments in Different Property Types: United States versus Europe .......... 70

Exhibit 14. Corporate Focus of Property Companies in Europe and the United States ............................................................................ 71

Exhibit 15. Diversification and Performance; Regression Results .................................... 72

Exhibit 16. International Correlation Matrices within Asset Classes ............................. 73

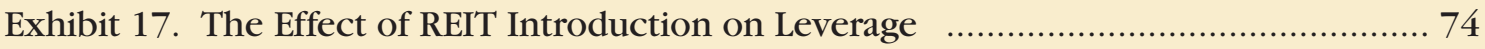

Exhibit 18. International Correlation across Housing Markets ......................................... 75

Exhibit 19. Example of a Company Structure to Avoid Corporate Taxation ...................... 76

Exhibit 20. Initial Public Offerings of Property Companies on European Stock Exchanges ……......................................................... 77

Exhibit 21. Initial Public Offerings of Property Companies through Tax Havens …........ 78

Exhibit 22. Initial Public Offerings of Property Companies on the AIM ........................ 79

Exhibit 23. Rodamco's Stock Performance During Open- and Closed-ended Regime ....... 80

Exhibit 24. Portfolio Composition of German Open-ended Funds .................................. 81

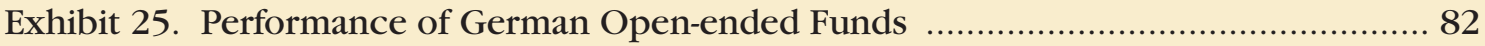




\section{Introduction}

Real estate plays an increasingly important role in the portfolios of both institutional investors and private savers. The main reasons are the diversification benefits this asset class has to offer and its qualities as a protection against inflation. These benefits have been documented by numerous empirical studies (examples are Brounen, Eichholtz and Theebe 2007, Eichholtz 1997, Goetzmann and Ibbotson 1990). Real estate investment generally improves the performance of mixed-asset portfolios.

To facilitate institutional and private investments in real estate, tax-transparent real estate investment vehicles have been introduced in a number of countries, both in Europe and in the rest of the world. Most of these initiatives date from the last decade, and have followed in the footsteps of early developments in the United States, the Netherlands, and Australia, where such real estate ownership structures have been introduced much longer ago: in 1961, 1969 , and 1971, respectively. These early initiatives were usually motivated by the wish to create an efficient and liquid way into property investment, especially for smaller investors.

The tax-exemption is granted to avoid double taxation. In the particular case of property companies, the goal is to avoid taxing a rental income stream at the corporate level and again at the shareholder level.Thus, exemption from corporate tax for a property company puts the shareholder in such a property company on equal footing with an investor who owns a property portfolio outright, since the rental stream for such an investor would only be taxed as income. In other words, corporate tax-exemption creates a level playing field between these two segments of the property market.The corporate tax exemption that generally holds for mutual funds has the same goal.

Of the $27 \mathrm{EU}$ members, 13 now allow some form of tax-transparency for real estate investment companies, but their exact structure varies considerably across countries: property companies in different EU member states face strongly differing operational requirements, investment rules, and financing restrictions. When making a cross-country comparison, one cannot help concluding that Europe's real estate investment regulation is a hodgepodge. This hampers pan-European property investment flows and discriminates real estate investors from countries in which tax-transparency has not been introduced. It also will lead to regulation arbitrage by investors.

In this respect, Europe compares unfavourably to the situation in the United States. Real Estate Investment Trusts (or REITs), as tax-transparent property investment companies are called in the United States, are an increasingly important avenue into the nation's real estate markets. Both private and institutional investors have used these REITs to get exposure to real estate in a liquid way. The United States is now the world's largest listed property market.

This report shows that there are strong arguments for one pan-European tax-transparent property vehicle: the EU REIT. These arguments mainly concern fair competition, free capital flows, and efficient allocation of - institutional - capital. The report proceeds as follows. After an introductory chapter entitled 'The Existing Landscape', in which Europe's position in the global property share market is discussed, the study is structured as follows. Chapter III, titled 'Problems of the Current Institutional Structure', will discuss the difficulties associated with the existing regulatory situation. Chapter IV, 'Policy Options: Zero Is Not an 
Option', will show the likely effects of the regulatory status quo, and in Chapter V, 'The Preferred Structure of the EU REIT', we will discuss what the EU REIT should look like in terms of governance, financing and operations, and open- and closed-endedness. We also provide the main arguments why property companies should be structured in the proposed way.The report will end with concluding remarks in Chapter VI. 


\section{The Existing Landscape}

The listed property industry has grown substantially in the last two decades. Pricing in this market is transparent, and it is more liquid than the underlying direct property market (Eichholtz, Op 't Veld and Vestbirk 1999). As a result, investors increasingly rely on indirect property investments as their preferred channel into the property market. Major European institutional investors, like pension fund PGGM from the Netherlands, now own more than $50 \%$ of their real estate assets through holdings in listed property companies. Especially for international investments into real estate, listed property companies represent the ideal avenue of choice: a leading pension fund like Britain's Hermes Pension Fund holds approximately $80 \%$ of its foreign real estate assets through listed property companies. Their importance for pension funds notwithstanding, property companies are even more important for small investors. For such investors, the typical scale of individual properties precludes direct access to the commercial property markets. Buying the shares of property companies provides access to real estate portfolios for even the smallest investors.

\section{II.1 The Global Market}

Exhibit 1 provides a graph of the development of the stock market value of this industry, distinguishing Asia and Oceania, Europe, and the Americas, and only considering property investment companies with a minimum market capitalization of US\$50 million. Globally, this market has grown from approximately $€ 28$ billion in the beginning of 1985 to more than $€ 1.2$ trillion as of June 2007. In all of the three major regions, growth has been especially strong in the last four years. Since property companies are generally also funded by debt, the combined value of the real estate these companies own is substantially larger than this global equity market capitalization. With an average leverage of approximately $40 \%$, this asset value would be approximately € 2.1 trillion.

The market for listed property companies has grown because of an increase in the average size of property companies, but also through an increasing number of listed property companies. For example, 202 property companies have done an initial public offering (IPO) in Europe alone since 1997, raising more than $€ 25$ billion, as shown in Exhibit 2. Especially in the past few years the market for the shares of European property companies has been extremely active.

Despite the strong growth of the global market, developments are very uneven when looking at the listed property market on a country level.This is illustrated by Exhibit 3, which provides a current overview of the global property share market, including both property investment companies and property developers. For each country in which listed property shares exist, it shows whether the country has a tax-transparent regime for property investment companies, and it provides the number of listed property companies (with a minimum market capitalization of US\$200 million), their combined market value, and the weight of that country's listed property market in the global listed property market.The first thing to notice in this exhibit is that most countries in which a substantial number of listed property companies exist have a tax-transparent regime for these companies. 
The Exhibit also clearly shows the dominant position of the United States, with 171 listed property companies larger than US\$ 200 million, and a combined market value of more than $25 \%$ of the global listed property market value. Measured by this market value, this country alone has a larger property share market than all of Europe combined.The United States is also the largest single market with a common legal and fiscal regime concerning property investment companies: the Real Estate Investment Trust (U.S. REIT).

Other countries with a thriving property share market are Australia, Hong Kong, Japan, and the United Kingdom.As a group,Asian countries seem to pull more than their weight when it comes to the listed property industry. That holds especially for Singapore, which has a far larger market than its economy would suggest: it has a $4.3 \%$ weight in the global market.

Looking at the European landscape, we can see a rather wide spread in the importance of the listed property share market across countries. To start with, not all member states have a listed property market, and when they do, the number of companies and their total market value varies considerably across countries. For example, Germany's market is relatively very small: much smaller countries like Austria and the Netherlands have a larger listed property share market. This can be partially explained by the investment focus on open-ended property funds rather than listed property funds in Germany: the aggregate market capitalization of the open-ended funds is substantial, but is not included in the data.

\section{II.2 Tax-transparent Regimes in the EU}

Currently, the EU-27 countries all apply a different legal and fiscal regime to the structure of their listed property companies. Some countries, like the Netherlands and the United Kingdom, have a tax-transparent structure in place, which means that investors benefit from single-layer taxation. Other countries, like Denmark and Sweden, do not have such a structure, implying two layers of taxation for investors in property companies. Exhibit 4 provides information regarding current tax regimes. For all $27 \mathrm{EU}$ member states, the exhibit shows whether they have a legal structure in place, and if they do, the year of introduction and the name of the structure.

Currently, 14 member states do not have any type of tax-transparent structure for property investment companies, nine of which are new member states. Of the 13 countries that do have a structure, eight have introduced it after 2000, most notably Germany and the United Kingdom at the beginning of 2007. Moreover, Spain, Italy and Poland are currently in the process of changing their old legislation into a more specific REIT-like structure, whereas Finland is expected to pass new REIT legislation soon. In other words, legislation regarding property investment companies appears to be changing quite rapidly in the EU. Moreover, the countries that have a special property share regime tend to change it quite frequently. For example, the Netherlands has introduced important requirements for its structure in 2001, which were changed again in $2007 .{ }^{1}$ Fiscal legislation with respect to property investment companies appears to be in a continuous state of flux. Most member states try to reinvent the wheel, each introducing their own peculiar do's and don'ts to their property share regime.There does not seem to be a standard to which all these national initiatives converge.

To get an idea of the peculiarities of the existing national tax-transparent property investment structures, Exhibit 5 provides information how the tax-exemption works for each of the 
13 countries that grant it. The major benefit for investors in a property company with a REIT-like structure is the tax exemption of the entity at the corporate level. However, this exemption is not equally applied to income and capital gains. These distinctions lead to unequal benefits for private and institutional investors from different European countries. The table shows, not very surprisingly, that rental income is not taxed at the corporate level. However, income from other activities than pure rent collection is often taxed. Usually, these activities involve property development activities, especially when the newly created property is subsequently sold on the market.

In all countries that have a tax-transparent structure in place, the tax-exemption is granted to avoid double taxation of rental income streams. Without the tax exemption, rental income would be taxed both at the corporate level and at the shareholder level. This would put the shareholder in a property company in a disadvantaged position relative to an investor who owns a property portfolio outright, since the rental stream for such an investor would only be taxed as income. The corporate tax-exemption is introduced to create a level playing field between these two types of investors.

In that sense, the legislation regarding REITs has firm roots in the tax legislation concerning mutual funds. For an individual investor who wants to invest in stocks, there are also two ways to do this, either through buying stocks directly, or through a mutual fund. The latter route has many benefits, but if these mutual funds would be required to pay corporate tax, using them would mean double tax payment:at the level of the corporation in whose shares the mutual fund invests, and at the level of the fund. Corporate tax exemption of mutual funds avoids that problem, and has allowed this industry to develop. Indeed, stock ownership through mutual funds is now a standard way for private investors to get access to the stock markets.

To illustrate how an EU citizen can acquire exposure to real estate in the EU, Exhibit 6 shows the cash flows for the various ways of investing, and whether these flows are taxed (red arrow) or tax-exempt (blue arrow).The outer arrows represent direct property investments, domestically or in another EU member state.The cash flows from the property are only taxed as income at the investor level. Second, an EU citizen can decide to invest indirectly in real estate - via a domestic property company or a domestic REIT ${ }^{2}$. In case of the former, the property cash flow is now first taxed at the company level and again at the investor level.A REIT structure avoids this double taxation, as it is tax exempt at the corporate level. However, if a REIT invests in property in another EU member state, the cash flows are taxed, so the EU citizen cannot invest indirectly in another EU member state without incurring double taxation. The third source of real estate investment exposure for an EU citizen is through a pension fund, a mutual fund, or an insurance company. Ultimately, the benefits received from these providers are taxed as income, so if these providers or their holdings pay tax, this amounts to double taxation as well.As Exhibit 6 shows, an EU investor who wants to acquire real estate exposure in another EU member state is very likely to be taxed twice.

\section{II.3 Dividend Requirements}

As tax-exempt property companies are not taxed at the entity level, taxes are levied at the investor level. To make sure that taxation indeed takes place, tax-transparent property vehicles in the EU are usually obliged to distribute a significant part of their net earnings. 
Both the level of distribution and the basis of distribution differ from country to country. Exhibit 7 shows that typically, payout is between $80 \%$ and $100 \%$ of realized earnings (recurring earnings). In some cases, distribution is even higher than this. For example, a French SIIC is also required to distribute $50 \%$ of earnings from property sales. There are exceptions, however. Most notably, Malta, Poland and Spain do not require any dividend payout, and the minimum payout in Greece is only $35 \%$ of fiscal profits.

Exhibits 5 and 7 already showed that dividend payout rules for property companies vary considerably across countries, and there are other fundamental differences between regulatory regimes regarding tax-transparent property companies. The fact that $13 \mathrm{EU}$ member states now have a tax-transparent property regime does not, unfortunately, imply that these countries treat listed property companies in similar ways. Indeed, tax-transparency is more or less the only thing they have in common.

Tax-transparent property vehicles usually face operational restrictions, financing limitations, and shareholder requirements. In other words, tax-transparency for property companies comes at a price, as the companies that comply with the regime will also have to abide by certain regulations. Typically, property companies comply with the rules in order to obtain a tax-exempt status, but this makes the European property share market very opaque and heterogeneous.To illustrate this point, the remainder of this chapter will provide an in-depth analysis of the characteristics of tax-transparent property company regimes across EU member states.

\section{II.4 Operational Restrictions}

Exhibit 8 shows operational restrictions and requirements for all EU member states in which a tax-transparent structure is currently in operation.Typically, operational restrictions can be grouped into rules regarding diversification, the freedom to get involved in property development and portfolio trading activities, and the type of assets companies can invest in. Overall, the common goal of the restrictions and requirements is to guarantee that property companies are low-risk passive investors, managing a real estate portfolio for their clients. But despite that apparent common goal, one cannot help noticing the rather random pattern in these requirements across countries. For example, some countries require a certain spread of the portfolio, mostly by requiring that not more than a certain percentage of the capital can be invested in any one property. Obviously, this requirement is implemented to reduce investment risk and to protect investors. However, the maximum percentage that can be invested in a single property varies considerably across countries, and other countries do not require such prudence at all, leaving the investment decisions to the property company.

Likewise, many tax-transparent regimes are associated with a limitation on development activities by property investment companies. For example, development is sometimes only allowed up to a certain percentage of total capital value, or only if the developed properties are held for a certain number of years. But similar to diversification requirements, exact requirements regarding development activities differ considerably across European tax-transparent regimes. In general, we can distinguish four categories: (1) no development activity is allowed, (2) development is allowed, but only to upgrade or add to the existing investment portfolio, (3) development is permitted albeit only in a separate, tax-paying entity ('stapled'), and (4) all types of development are allowed within the structure. In some countries, like 
Germany, property development activities are not at all allowed, whereas in other countries, like the Netherlands, development activities are allowed under a separate taxed entity. Regulators quote fair competition with pure property developers - who are taxed like normal corporations - and a need to limit the active risk-taking by property companies as reasons for the restrictions. However, in countries like France and the United Kingdom the limitations are less strict and in some other countries with a tax-transparent structure, they are nonexistent. Examples are Austria and Poland.

Lastly, tax-transparency often requires limitations regarding the nature of the assets that a property company can invest in. Not surprisingly, many regimes demand a certain minimum percentage of invested capital into real estate, and some countries even have requirements regarding the type of real estate a property company can invest in. Germany's tax-transparent property companies, for example, are not allowed to invest in housing. Besides these requirements, there are sometimes rules regarding minimum or maximum allocations to more liquid financial assets, and even loans.Again, the rules vary quite strongly across countries, and some countries do not deem it necessary to prescribe anything in this regard.

\section{II.5 Financing Restrictions}

Tax-transparent property vehicles in most countries are set up as passive investment vehicles, aiming to offer their shareholders relatively stable returns. Since high debt levels are usually associated with high risk for shareholders, regulators often curtail debt financing in order to protect the shareholders and to safeguard the stability of the property investment companies. Under the majority of property company regimes in the EU, borrowing is indeed limited.

Exhibit 9 shows the regulations regarding the capital structure under the different REIT-like regimes in the EU. The limitations to take on debt vary quite strongly across countries. Spanish rules regarding Real Estate Investment Companies (REIC) are most strict, stating a maximum leverage of $10 \%$. The United Kingdom is at the other end of the spectrum, without any limits on borrowing (interest-coverage test only). Most other countries' leverage limit varies between $40 \%$ and $60 \%$ of asset value.

The major differences that are observed can have a substantial impact on the financial performance of a property company. Although the costs of borrowing are higher for a tax-transparent than for a tax-paying property company due to the lack of a tax shield, borrowing still contributes to performance - as long as the cost of debt is lower than the yield on property. Therefore, putting a ceiling on the amount of debt is likely to have a negative impact on the performance of property companies. Furthermore, debt is a very important financing source for tax-exempt property companies, as these have to visit the capital market frequently due to the obligatory payout of net earnings. Prohibiting property companies from using debt can therefore considerably hamper their growth. This is especially the case in periods when debt is relatively cheap, as was the case until 2007.

\section{II.6 Shareholder Requirements}

Companies with a tax transparent structure often have to comply with certain shareholder requirements. The rationale behind these requirements is to ensure the proper use of the 
structure and liquidity of the shares. In most cases, shareholder requirements translate into a minimum number of investors or a specific percentage of shares that investors are allowed to hold in a company. This can influence the free-floating market capitalization and liquidity of the property shares.

In Exhibit 10, we sketch the various shareholder requirements that apply under the different European REIT-like regimes. Consistent with evidence on other rules and regulations connected to REIT-like regimes, the exhibit clearly shows how restrictions differ per regime. Only Bulgaria has a shareholder regulation that actually requires institutional shareholders to be present as investors, the other countries with specific regulations regarding shareholders have requirements that disperse the ownership base.

Besides rules on ownership dispersion, mandatory listing is a rather common requirement for tax transparent property companies: it is required in six countries. This might have implications for competition between companies operating under different REIT-like regime in EU member states, as an equity offering on the stock exchange is not always the optimal solution to obtain equity financing. Being publicly listed yields various benefits, for example easy access to capital and debt. However, the drawback of a public listing is that the stock market does not always value a property company according to its fundamental value. Stock market sentiment becomes part of the fund price movement and very often market prices exhibit strong deviations from the net asset values (NAV) of the underlying property portfolio (Barkham and Ward 1999). When stock value is low compared to the NAV, this results in a discount, which can be a major limitation for future investment plans.

To conclude, the global property share market has shown strong growth since the mid-1980s, and especially in the last three years. Many countries, in which listed property companies exist, also have a tax-transparent regime for such companies in place. Comparing the EU's position in this market to the rest of the world, the EU seems a bit under-represented, especially given the maturity of its capital markets. Out of the 27 EU member states, 13 countries now have some kind of tax-transparent legal structure for property companies, but these structures differ considerably per country, and the European Union is far from a single market in this regard. The next chapter will look at the differences in more detail, and will analyze the possible effects this has on property markets, investment performance and the position of investors from smaller member states. 


\section{Problems with the Current Institutional Structure in the EU}

As we showed in the last chapter, the European landscape of property share regimes is far from homogeneous. Many EU member states do not have a tax-transparent legal structure for property companies and in the countries that have such a structure, the differences are considerable. This creates a number of disadvantages for savers and investors in EU member states, especially for those based in member states that lack tax-transparent structures.

We argue that the current situation leads to six major disadvantages, and the remainder of this chapter discusses each disadvantage in turn. First, the current situation distorts competition between member states. Investors from member states without tax-transparency are at a disadvantage to other investors, both from other EU member states, and from countries like the US and Australia, where tax-transparent property vehicles are common. National differences in withholding tax treatment are an additional source of unfair competition.

The second major disadvantage of the current institutional situation in the EU is that it hampers growth in cross-border property investment across the EU. United States REITs, which are in no way hampered in their investment strategy, are mostly sector specialists, investing across the greater part of the United States. On the other hand, most European property companies invest only in one country. This lack of cross-border property investment by EU property companies limits their scale, and forces them to invest across a spectrum of property products, whereas the pan-American scope of United States REITs allows specializing in rather narrow market niches, like senior housing and healthcare property. In Europe, such strong specialization is very rare.

The third disadvantage of the current situation is an effect of the lack of product specialization by EU property companies.As we will show, there is strong empirical evidence that the U.S. REIT strategy of sector focus and geographic diversification is performance-enhancing: property companies that specialize in one property type typically have a higher risk-adjusted performance than companies that diversify across property types. That means the current situation in the EU forces property companies to adopt a relatively weak strategy.

The fourth problem is that the existing legal landscape discriminates small member states and their savers. The academic evidence for the benefits of international property investment is very convincing: investors (and their clients) from small member states without a tax-transparent structure will not harvest the fruits of international property diversification, and will be worse off. This also leads to international capital flows not being distributed optimally across property markets of member states. Besides that, sector specialization has been shown to be beneficial for property performance, but such specialization is difficult in small member states, due to lack of scale.

Fifth, the weak strategic position of EU property companies and the obstacles to international investment lead to suboptimal allocation of property investment capital in the EU. Advantages of scale and scope are not optimally harvested by EU property companies, and the fragmented market impedes optimal diversification by investors, especially those located in smaller EU member states. Furthermore, corporate real estate is currently a major asset on the balance sheet of most European companies, which has been shown to be inefficient. It would be easier to spin-off corporate real estate assets with pan-EU REIT legislation in place. 
Lastly, the current situation does not provide incentives for market parties to behave in ways conducive to market safety and security. Double taxation provides a clear incentive for property investors to take on debt, thereby increasing risk. Since the lack of a pan-EU property share regime hampers cross-border property investment in the EU, property investors are not optimally diversified, thereby increasing systemic risk.

In this chapter, we will discuss these disadvantages, based on the current academic literature, and on additional quantitative economic analysis.

\section{III.1 Distorted Competition}

As we documented in Chapter II, the current regulation regarding listed property companies differs strongly across the EU. Restrictions on operations, the capital structure and shareholders create an uneven playing field for EU property companies and their investors. However, the situation regarding distorted competition is most blatant when it comes to withholding tax treatment of cash flows in property companies. There is often tax leakage when REIT shareholders are not resident in the same member state as the REIT itself.

Currently, domestic and foreign shareholders in listed property companies are treated differently under various tax-transparent regimes in the EU, which implies that private savers and institutional investors in different European countries face investment opportunities that are not similar. Differences can be substantial, with investors in Luxembourg paying no withholding tax, as compared to a $22 \%$ withholding tax rate that is applied in the United Kingdom. At the moment, many EU member states impose protective tax measures that prevent shareholders from other member states from benefiting from the same withholding tax exemption granted to local resident taxpayers.

Exhibit 11 shows an overview of the current legislation. The differences across countries are substantial. In Austria, the Netherlands and Spain, a different withholding tax rate is applied to capital gain distributions and dividend income respectively, whereas in other countries the two income components are treated in a similar way. Furthermore, many countries not only discriminate between domestic and other EU investors, but also differentiate between the countries of origin of EU investors, following double taxation conventions concluded between member states. Here also, the observer cannot avoid a sense of arbitrariness when looking at these differences. For example, in Belgium, France, Greece, Italy and Spain, a special withholding tax to foreign investors applies, with might be reduced pursuant to tax treaties. France has, in addition, adopted a special rule, which excludes foreign corporate shareholders from withholding tax reduction when shareholdings exceed $25 \%$.

Moreover, private and institutional investors are not treated in the same way. EU tax-exempt shareholders are for instance fully refunded in the Netherlands. The taxation issue of property companies investing in other member states, and of investors investing in other member states via local tax-exempt property companies is currently addressed via a fragmented approach, in which each member state has developed its own legislation.This has lead to a situation of unfair competition among both property companies and investors. Clearly, EU REIT legislation would have to address this issue. 


\section{III.2 Impediments to Specialization}

The management of a property company can adopt several investment styles, e.g. management can decide to focus investments or to diversify, to engage in active management such as developing or rehabilitating properties, and management has the freedom of organizational restructuring (Capozza and Seguin 1998). We discussed the possibility of including development in operations in Section II.4, but in this section, we will elaborate on how managerial style in property companies affects specialization and diversification.

Diversification comes in two forms: first, a property company can diversify its investment over more than one property type, where common property types are for example residential, retail, office and industrial real estate. More specialized property types include for example senior housing, warehousing, hotels, self-storage and prisons, or deeper specialization within common property types, for example high-street shops or regional shopping malls within the retail property category. Secondly, a property company can diversify its investments over more than one country. In Europe, property diversification is commonly achieved by investing in more than one sector. Geographical diversification is less common. Exhibit 12 shows the current diversification of European property companies, based on the European part of the GPR General universe, which consists of all listed property companies with a market capitalization exceeding $\$ 50 \mathrm{mln}$. The exhibit clearly indicates that European property companies are strongly diversified over different property types, with almost three-quarters of the sample investing in more than one property type. Moreover, European property companies seem to have a strong preference for office and retail property. International diversification is less widespread: less than a quarter of the property companies in our sample invest in more than one country (with a minimum investment threshold of $25 \%$ ).

Contrasting to Europe, property companies in the United States are generally focused on one sector and rather geographically diversified. For U.S. REITs, it is possible and easy to diversify across state borders, as a nationwide and coherent structure for property companies is in place.This allows for critical mass within one property type, which might lead to economies of scale and scope. Indeed, U.S. REITs are very often 'super-specialized', meaning that they invest in a segment of a property type. For example, retail property investors usually don't invest in all types of retail property, but just in regional malls, or only in strip malls. Larger property companies, with higher quality management, will be better positioned to acquire properties and position them for rent growth.

\section{Specialized Property}

We argue that property companies in the United States can obtain economies of scale in a specific property type by investing across state borders. In practice, this has lead to an abundance of property companies that specialize in 'alternative' property types, such as healthcare, hotels, prisons, warehouses and schools. The efficient U.S. REIT market has also enabled property companies active in entirely new property categories to grow and prosper, for example in self-storage facilities. This was a virtually non-existent market 20 years ago.

An important part of the property market now serviced by U.S. REITs can be classified as 'social' property, traditionally financed and owned by the government. At a time when public finances are stretched, this involvement of the private sector in development, financing 
and securitization of 'social' property has secured its supply and quality.The tax-exempt REIT structure is especially suited as an investment vehicle in 'social' property, as it allows institutional investors to get exposure to low-risk property, without a double layer of taxation. To provide a first illustration how the REIT structure has influenced the creation of specialized property companies, Exhibit 13 shows the portfolio compositions of U.S. versus EU property companies across the major property types. In the United States, healthcare and hotel property represent significant securitized property types, with a share of $10 \%$ and $13 \%$ of total REIT investments respectively. In Europe, investments of publicly listed property companies in these kinds of property are still small. Moreover, the exhibit shows that the more traditional property sectors - office and retail - represent $66 \%$ of the property investments of European listed property companies in Europe, whereas in the United States this percentage is $41 \%$, indicating that investments are directed more towards other property types.

To provide some more insight into the different types of specialized property companies and how securitization can be beneficial to these sectors, we briefly describe the senior housing and healthcare property sector, the student housing sector, and the correctional property sector.

\section{Senior Housing and Healthcare Property REITs}

The demographic wave of aged people that is steadily approaching in many parts of the world is already translating into higher demand for privately and publicly funded senior housing real estate. The National Investment Centre for the Senior Housing and Care Industry (NIC/PriceWaterhouseCoopers 2001) predicted additional capital needs of almost $\$ 5$ billion for the US industry alone by 2005 , and almost $\$ 25$ billion by 2010. In many EU member states, the short- to medium-term need for senior housing is likely to be comparable or even more substantial, since the aging of the population is more advanced in most EU member states than it is in the United States.

It is likely that the capital needed in the senior housing industry will be increasingly supplied by institutional investors, as governments will not always be able to carry the burden. In a study on who should own senior housing, Eichholtz, Kok and Wolnicki (2007) find that specialized real estate operators like REITs are often able to manage senior housing more efficiently than healthcare companies, like hospitals and nursing homes. Especially for 'independent living' property investments, healthcare REITs have higher returns than integrated healthcare companies. This might be caused by the fact that real estate and care services are unrelated components of revenue in the independent living segment, so managerial added value is limited here. Moreover, brand identity plays a minor role in this segment, as care services can only be provided by means of housekeeping and social activities.This suggests that healthcare REITs are efficient owners of senior housing in the independent living segment.

There are three U.S. REITs that operate on the senior housing market: Chartwell Seniors Housing (CHS), Sunrise Senior Living (SRZ) and Senior Housing Properties Trust (SNH). In addition to these three REITs, there are ten healthcare REITs that have hospitals, medical office buildings, assisted living facilities and skilled nursing facilities in their portfolio. As healthcare properties are relatively costly to develop, most REITs acquire existing buildings, and do not engage in development activities. 
Traditionally, the student housing market has been dominated by universities offering housing to their students, mostly on campus. However, in most EU cities, the universities cannot cope with the increased demand, and universities do not very often use the U.S. campus model, making them less logical suppliers of student housing. This means that students have to rely on the private supply of student housing. This private market consists of many small suppliers owning a few apartments or small student complexes. The buildings are often of bad quality and come at a high price.

At the same time, per-unit rents for student housing generally exceed those for conventional apartments, as units have more tenants paying rent. Rents in the student housing sector are roughly 30 percent higher than for conventional apartments (Nelson 2007). Rents and occupancy tend to be less sensitive to economic cycles than conventional apartments falling less in economic downturns, and increasing less during economic expansions. Furthermore, rents are typically reviewed annually in the student housing sector, where the typical term for offices is five years or longer.The demographic outlook for the student housing sector is strong, due to increased university participation.

Under these market conditions, investment opportunities exist for companies that focus on large housing complexes for students. However, the fragmented supply of student housing limits the possibilities of (institutional) investors to enter the market directly. In the United States, several REITs have emerged that specialize in student housing, contributing to investor awareness and financial transparency in the sector.American Campus Communities was the first public student housing REIT and has been listed since 2004. The student housing REIT owns or manages 42 properties with 26,400 beds and provides leasing and management services at a total of 57 properties with approximately 35,700 beds. GMH Communities Trust owns both student and military housing. Its portfolio includes 77 properties and 46,696 beds, and it manages more than 40,000 student housing beds. Education Realty Trust owns or manages 66 properties with 40,742 beds in 21 states. Since going public, the three student housing REITs have expanded rapidly, increasing their portfolios from a combined 47,200 units at year-end 2004, to 133,200 as of February 2007 (Nelson 2007). The REITs have enlarged their portfolios through individual asset and portfolio acquisitions, as well as new development.

\section{Correctional Property REITs}

A third specialized property sector that could benefit from a homogenous REIT structure is the market for correctional properties. In the United States, this has been a growth market, and three major listed companies now offer correctional property: Cornell Companies (CRN), Corrections Corporation of America (CCA) and GEO Group Inc. (GEO). The portfolios of these companies consist of all kinds of correctional facilities, such as prisons, jails, juvenile and adult detention facilities, and specialty detention facilities designed for specific types of criminals. Companies operating in this sector acquire these buildings and lease them to governments, thereby alleviating the governmental budget. Sometimes this involves a sale-andlease-back construction of existing prisons, but in most cases, the companies build new facilities that are operated privately.These lease contracts are typically for a long term. 
In addition to the offering of detention facilities, these companies offer a total package of services. Most companies even operate these prisons, and offer additional services, such as juvenile and adult programs, after-care programs, educational programs, and the transportation of criminals (Fitzgerald 2004). The main reason states contract with private jailers is to cut costs. CCA claims it typically charges 5-15\% less per prisoner than a state would spend. This is mainly due to economies of scale: it guards more prisoners than any state except California,Texas or Florida. It can assemble a jail quickly and cheaply using standardized parts. It lacks a state's cumbersome bureaucracy. It builds smart jails, where fewer staff can watch more prisoners, and it builds where land and labour are cheap. In other words, private suppliers of correctional property may be more efficient than the public sector, without quality concessions.

To conclude, the U.S. REIT market shows ample experimentation with property types that have traditionally stayed out of reach of the capital market. We have discussed three of those, but the list is longer.The uniform institutional setting for U.S. REITs has created fertile soil for the germination and further growth of experiments with non-traditional property. In the EU such experimentation is still rare, but that is not for lack of potential property products. For example, buildings used by the government tend to be owned by it as well. That holds for all levels of government in the EU's member states. The question is, however, whether the government is the best and most efficient landlord, and whether it wouldn't be more efficient and flexible to rent rather than own real estate. That question can also be raised for other EU sectors with large property ownership, such as the military, health care (both in cure and in care), social housing, and education.A uniform EU regime for property companies will stimulate the involvement of the institutional capital market in these property types.

\section{III.3 Effects on Investment Performance}

There is an abundance of literature regarding the benefits of economies of scale in the real estate sector, and nearly all of the literature is based on U.S. property companies. The overall consensus coming out of that literature is that larger property companies benefit from economies of scale. Lewis, Springer and Anderson (2003) and Devaney and Weber (2005) both show for a sample of U.S. REITs that property companies face increasing returns to scale and conclude that U.S. REITs would benefit from expanding the scale of their operations by expanding their portfolios.

Ambrose, Highfield and Linneman (2005) test for scale economies in U.S. property companies by examining growth prospects, revenue and expense measures, profitability ratios, systematic risk and capital costs. They find that large REITs have increasing growth prospects and lower costs, leading to a direct relation between firm profitability and firm size. Additionally, they find an inverse relation between equity betas and firm size, and for all cost of capital measures they find significant scale economies. In a study that is important from an investor point of view, Conover, Friday and Sirmans (1998) study the performance of real estate stocks using an international sample and find that firms with large market value of equity have higher returns and lower risk as compared to small listed property firms. Evidence of higher quality management at larger property companies is documented by Brady and Conlin (2004), who find that hotels owned by U.S. REITs have higher revenue growth and higher occupancy growth, as compared to privately owned hotels. This outperformance is mainly due to better acquisition decisions. 
The only exception to the consensus regarding the positive size effect is a study by Ambrose, Ehrlich, Hughes and Wachter (2000). These authors do not find evidence that large REITs have higher growth rates of Net Operating Income than small REITs.

Generally, economies of scale improve efficiency in the real estate sector. Property companies in the United States mainly obtain a larger scale by investing in one property type while diversifying across regions. However, a larger scale can also be obtained by diversifying across property types, as listed property companies in Europe generally tend to do. The issue of corporate focus versus corporate diversification has been widely discussed; not only in the academic literature, but also in corporate boardrooms. The prevailing view until the 1970 s was that diversification would lead to lower correlations between earnings streams and thereby decrease default risk and capital costs. However, this view changed in the late 1970s and early 1980s, when shareholders and academics started to realize that corporate diversification also lead to less transparency of operations and increased information asymmetry. The resulting agency costs were found to offset the potential benefits of diversification. This change in thinking was based on studies like Montgomery (1974), who surveys the finance literature concerning corporate focus, and finds a negative relation between corporate diversification and financial performance in the majority of academic studies.

In the real estate literature, several studies investigate the relation between corporate focus of property companies and their risk and return profiles. For the U.S. REIT market, Capozza and Seguin (1999) trace the effects of corporate focus by examining the relations between focus, cash flows, and firm value. They show that diversification reduces value, but this is not due to poor managerial performance. Project-level cash flows are actually higher for less focused firms. However, these gains are offset by higher management, administrative and interest expenses.They attribute some of the effect of focus on the cost of both debt and equity to informational asymmetries or transparency costs. Eichholtz, Op 't Veld and Schweitzer (2000) study the relation between specialization by property type and geographic location and the performance of U.S. REITs. They find that companies specializing in a specific type of property outperform the market, whereas geographical specialization results in underperformance.

Cronqvist, Högfeldt and Nilsson (2001) find an ex ante discount for diversifying companies. They surmise that investors anticipate extra costs in the diversification process. The extra costs consist of companies paying too much when acquiring new assets and allocating too many resources to the process of integrating the new assets. Moreover, their results show that rents get dissipated in the diversification process. Similarly, Brounen and Ter Laak (2005) investigate the discount to net asset value (NAV) that is often observed for property companies. A major explanation for the discount is the degree of property type diversification: the more property types a property company invests in, the higher its discount to net asset value. Only property type appears to matter in this respect. Regional diversification does not play a role, which could be due to the relatively high degree of regional focus that is present in their sample of European property companies. As we have shown earlier, these tend to be rather domestically focused when it comes to an international diversification strategy.

For an international sample of property companies, including four European countries and the United States, Boer, Brounen and Op 't Veldt (2005) statistically confirm the remarkable difference in corporate strategies between U.S. REITs and European property companies. In the United States, property companies generally focus on one sector and diversify across re- 
gions, whereas in Europe, property companies mainly focus on the local market, but diversify across different property sectors. In line with our contention, they explain the difference by the lack of a coherent legislation in the European property market, which obstructs property companies' investment in markets outside their local territory and forces managers to diversify across property types. The latter is detrimental to performance, as the results show that sector focus increases risk-adjusted stock returns. Geographical focus leads to higher stock returns, but these come with higher risk.

We argue that the lack of a single property investment vehicle for Europe does not allow European property managers to implement their corporate strategy in an optimal way, as cross-border investments are hindered by differences in legal frameworks between European countries. This has lead to diversification across property types, which - as empirical evidence has shown - affects performance in a negative way. However, the existing studies hardly use data for EU countries, and they are mostly based on rather old data. That is why we conduct additional empirical analysis, directly comparing the situation in Europe to that in the United States. We have data on the portfolio compositions of a sample of European and American property companies. For this sample, we first statistically measure the level of diversification, both across sectors and across regions, and subsequently relate our diversification measure to financial performance.

We distinguish eight different property sectors: healthcare, hotels, industrial, office, residential retail, warehousing and others. For the United States, the data on the portfolio composition of REITs is from the National Association of Real Estate Investment Trusts (NAREIT). We divide the United States in seven regions: Middle Atlantic, Midwest, New England, North Pacific, Plains, South Pacific, Southeast and Southwest. For the EU, we use data provided by Global Property Research (GPR), and geographical diversification is determined based on country borders. The degree of diversification is measured by calculating two Herfindahl indices for each property company: one measuring specialization/diversification by property type, and one measuring specialization/diversification by region. The Herfindahl index is an often-used measure of corporate diversification or specialization that can vary between zero and one. A number close to zero indicates a high degree of corporate diversification, and a number close to one indicates that a company is very specialized.

Exhibit 14 shows the Herfindahl indices for U.S. REITs and European property companies, where we distinguish between property type diversification and geographical diversification. In line with existing academic evidence, the data shows that property companies in Europe have a strong geographic focus, with a geographical Herfindahl index of 0.84 and investments in two countries on average.This is opposed to U.S. property companies, which strongly diversify investments across regions, with property investments in five regions on average, and a geographical Herfindahl index of 0.42 .

At the same time, European property companies tend to diversify more across sectors than do property companies in the United States, with a property type Herfindahl index of 0.60 for the former, against 0.82 for the latter.The findings are consistent for both the Herfindahl indices and the average number of regions or sectors that a property company invests in, and the significant $t$-statistic indicates that the degree of diversification of U.S. REITs across regions in the United States is significantly higher than diversification across countries for European property companies. These findings clearly illustrate the difference in management style prevailing in both continents; the ease of investing across state borders in the United 
States results in sufficient scale to focus on one property type. In contrast, country borders in Europe are limiting property managers in international investments, forcing property companies to invest locally and to diversify across property types.

As a next step, we relate the Herfindahl index, our measure of diversification of listed property companies, to the financial performance and firm valuation of property companies. We use Jensen alpha as a measure of risk-adjusted historical performance. With Jensen alpha, the realized total return of a firm's stock is corrected for its systematic risk. The alpha measures the additional return a stock generates, above the return an investor could expect on the basis of the risk of that stock. In other words, alpha measures value-added for the shareholders, and if a company is able to outperform the market, this will result in a positive Jensen alpha. To calculate the alpha for each of the property companies in the sample, we collect monthly stock return data for the period from 2000 through 2006 from Datastream, and we correct the return of each individual property company for the performance of the local real estate market using the Global Property Research national indices.

To formally test the relation between diversification and performance of property companies, we employ an ordinary least squares (OLS) regression model, in which we control for other factors that may influence the stock performance or stock valuation of a property company. These control variables are based on standard finance methodology and include the leverage ratio (Black, Jang and Kim 2006), company size (Shin and Stulz 2000) and dividend yield (Eichholtz, Op 't Veld and Schweitzer 2000).

We present the results of this analysis in Exhibit 15. For sake of clarity, we leave out the coefficients of the control variables (available from the authors upon request). In model (1), we focus on the relation between geographic diversification and performance. For the European sample of property companies, the results show a statistically significant and positive relation between the Herfindahl index and Jensen alpha.This finding indicates that European property companies that invest cross-border underperform property companies that focus on a single national market. Contrasting the results for the European sample, the results for the U.S. REIT sample show that property companies with investments in more than one region perform better than property companies focusing on a single region. This finding is indicated by the negative regression coefficient.

As we argued earlier, the contrasting results for the European sample and U.S. sample are likely to be due to the existence of different legal frameworks across the EU hindering European property companies from performing well internationally. Companies that execute a pan-European strategy have to deal with a wide variety or rules and regulations, which is detrimental to performance. In the United States, property companies face fewer legal differences when investing in different states and the economic benefits of diversifying across regions are therefore not offset by higher costs. Thus, the performance evidence for the United States indicates that the U.S. model is the optimal form of industry organization if national market barriers fall away. In other words, a pan-EU REIT regime is likely to create pan-EU property investment by property companies, which will benefit performance.

In model (2), we focus on the relation between property type diversification and stock performance. For Europe, we find a negative but statistically insignificant coefficient, which suggests that European property companies investing in more than one property sector outperform property companies focusing on a single property sector, albeit very weakly. In 
contrast, the results for the sample of U.S. REITs are positive and statistically significant and in line with existing academic evidence: specialized property companies clearly outperform diversified companies.As argued earlier, property type specialization generally leads to more focused operations, which explains the outperformance of focused U.S. REITs. With a pan-EU REIT regime, EU property companies could harvest the same benefits of specialization as their U.S. counterparts.

To conclude this section, the academic literature shows that economies of scale hold for property companies. Moreover, companies that focus on a single property type generally outperform diversifying property companies, whereas broadening the geographic investment scope enhances performance. The academic evidence is supported by our empirical findings, indicating that the current situation regarding property companies in EU member states is not value-enhancing.

\section{III.4 Disadvantages to Individual Member States}

For investors, risk reduction through portfolio diversification is a key element of the investment strategy.This has been clear even before Markowitz' (1952) formal development of portfolio theory. If two assets are not perfectly correlated - i.e. the returns do not move perfectly in line with each other - the combination of both assets leads to a higher rate of return for the same level of risk or, a lower level of risk for the same level of return. The portfolio theory holds for property investors as much as for investors in stocks and bonds. The theory does not necessarily imply that property companies need to diversify themselves. In the previous section we showed that specialization by property companies could create shareholder value, especially in focus on property type. So, it is probably best if property companies focus, whereas their shareholders - institutional and private investors - should hold diversified portfolios of listed or unlisted property companies.

Diversification of real estate investments can be accomplished inside a country - regional diversification - and there is abundant literature showing the benefits of regional diversification within the United States. Early evidence is from Hartzell, Schulman and Wurtzebach (1987), who find that regional diversification does matter for real estate portfolios. They argue that regional diversification works because local economies have different drivers. This hypothesis was later confirmed by various studies like (Eichholtz, Hoesli and MacGregor 1995, Giliberto and Hopkins 1990, Hopkins and Testa 1990, Mueller 1993, Wurtzebach 1988).

Although the concept of regional diversification of real estate investments is attractive to investors, the implementation of this investment strategy for EU citizens is only viable up to a certain extent. In smaller member states, like Austria, or Estonia, regional economic differences are small and diversification within the country will not lead to sizeable risk reduction. But even in larger EU member states like Germany or France, regional differences are not likely to be substantial enough to spread real estate investments across regions and obtain substantial diversification benefits.

The Netherlands is a member state whose institutional investors traditionally have been well capitalized due to high pension savings. The combined capital of these investors is very large relative to the local capital market, so Dutch institutional investors have a tradition of investing abroad, not just in property, but in other asset classes as well. Dutch property com- 
panies have aided their institutional clients through an international investment focus. This has coincided with an early implementation of the REIT structure in the Netherlands. So by investing in listed property companies, Dutch private and institutional investors have been able to obtain exposure to international real estate markets. However, in most small EU member states international property companies are scarce, while the relative lack of diversity in investment opportunities at home would make international investment all the more important.

The risk-reduction potential of international investments has been well documented in the finance literature for stocks and bonds, by for example Solnik (1982), Grauer and Hakansson (1987), Levy and Lerman (1988) and more recently by De Roon, Nijman and Werker (2001). For listed real estate companies, Eichholtz (1996) demonstrates that diversification benefits of international investment are even bigger than for stocks and bonds. His study investigates correlations between national property markets, and compares those with correlations between bond and stock markets. Since the property correlations are significantly lower than the correlations in the other asset markets, the conclusion is that international diversification works better for real estate. These results are confirmed by Conover, Friday and Sirmans (2002). More recently, Glascock and Kelly (2007) show that diversification across countries can decrease portfolio risk for real estate investors more strongly than diversification across property types.

To some extent, the benefits of regional or international diversification may be a self-destroying phenomenon. International investment, and the international capital flows that are associated with it, could potentially lead to synchronization between asset markets. For example, Eichholtz' (1996) study is based on data for the early '80s and '90s. Since then, international capital flows in property markets have gone up, partly aided by the development of the global listed property market we showed in Exhibit 1. Besides that, some market fundamentals, like the introduction of the Euro, may also have created more international capital market integration and less diversity, which might lead to less potential for international diversification. For bond investors, such decreasing international diversification benefits are indeed clear to observe: bond yields across Europe have converged very strongly in the last 10 years. The question is whether that also holds for real estate. Lizieri, McAlister and Ward (2003) specifically address this, based on data from 1983 to 2001. Using a broad range of econometric tests, they conclude that the dispersion of performance across property markets is higher and correlations are lower. In other words: cross-regional diversification is still very important for property investors.

To investigate empirically whether the international diversification potential of real estate is still available to investors, we update and expand the research conducted by Eichholtz (1996) based on more recent data. We analyze international correlations for 12 countries, seven of which are EU member states. As we aim to compare real estate portfolio diversification with diversification potential for stocks and bonds, we look at commonly used total return indices for property shares, stocks, and bonds for each of these 12 countries, running from January 1995 until June 2007. We subsequently calculate international correlations between the returns of these countries for each asset class.

Exhibit 16 provides the international correlations for each of these three asset classes.As one can clearly see in this table, international correlations among national property share are nearly always lower than those among stock markets and bond markets. These results are 
very much in line with those found by Eichholtz (1996), despite the increased capital market integration since that time.Apparently, property markets are still strongly driven by local factors. This is likely to remain the case: property pricing is known to differ strongly and persistently between local sub-markets. That suggests even greater potential pricing differences across countries, and therefore sustained diversification potential.

The literature and evidence presented in Exhibit 16 clearly shows the benefits of regional and cross-border diversification for investors in EU member states. As we pointed out earlier, regional diversification might be possible to a limited extent for investors in relatively large member states, but is not at all possible for investors in small member states. Moreover, crossborder property investments in the EU are obstructed by strong institutional differences: first, a tax-transparent REIT-like structure is not available in every EU member state and therefore cross-border property investments by REITs in member states without a REIT structure are taxed. For example, a citizen from France who holds shares in a French property company that invests in Romania will incur double taxation - at the investor level and at the fund level in Romania - even though the property company in France has a REIT structure. Second, for an institutional investor from one member state who buys shares of a listed property company in another member state with a REIT-like structure, a withholding tax often applies. This implies that even though the investor in principle avoids being subjected to double taxation by investing in a REIT of another member state, the property cash flows are still taxed.

Although the possibility of cross-border investments is equally beneficial to institutional and private investors in all member states, the adverse effects of the lack of this possibility especially affect the investors in small member states. This is first of all because these countries partially miss out on international capital inflows in their property sector and second, because cross-border property investments are more beneficial if the local property market is small.

To conclude, international diversification is very important for EU property investors, despite the capital market integration that has taken place in recent years. Of the small EU member states, the Netherlands has been the country where such international investment has been going on for decades, aided by the international outlook of its listed property companies. It is likely that the well capitalized institutional sector in combination with the early introduction of an efficient tax regime for such property companies have been the drivers for this development, enabling Dutch investors - private and institutional - easy access into the foreign property markets.An EU REIT structure will facilitate cross-border investments for property companies throughout the EU, thereby unlocking real estate assets in small member states that are currently without a REIT structure. This will enable private and institutional investors in EU member states to gain international diversification in property investments, thereby lowering risk while keeping returns constant.

\section{III.5 Poor Allocation of Capital}

In the previous chapters, we already provided fundamental reasons why the current patchwork of legal regimes regarding property companies in EU member states is not efficient. In essence, each argument leads to suboptimal allocation of capital. We argue that an EU REIT will lead to more efficient capital flows in the real estate sector, i.e. capital will flow to the markets or sectors that are under funded.This is in line with market efficiency, as opposed to the current situation, which prevents efficient allocation of capital. Property companies 
cannot freely invest across country borders, which leads to property type diversification rather than geographic diversification. Capital flows are obstructed and do not flow freely into property markets that offer the best investment opportunities. Although EU cross-border property investments have increased from virtually nothing to 96.5 billion euro in 2004 (Jones Lang LaSalle, 2004), this is still only $2.5 \%$ of the total size of the commercial real estate sector. Moreover, the degree to which property investors are international is very uneven: Dutch institutional investors make most of these cross-border property investments.

Furthermore, property companies have difficulties in obtaining sufficient scale in a specific property type, so economies of scale are not optimized and specialized property like healthcare facilities is harder to aggregate and to securitize. Moreover, opportunities for international diversification are limited as not all member states have a (similar) tax-exempt structure, and foreign investors are often discriminated by a withholding tax. On top of these inefficiencies in capital allocation, this chapter discusses two other consequences of the current situation. First, it has been shown that the lack of a tax-transparent structure leads to undervaluation of property companies on the stock exchange. Second, the lack of a pan-EU REIT structure hinders companies in spinning off corporate real estate assets.

\section{(i) Discounts to Net Asset Value}

Investors that acquire property directly are taxed only once. If an investor instead decides to invest indirectly, for example because this overcomes the problem of lack of local knowledge when investing abroad, the investor is taxed twice. This problem is often solved by corporate tax-exemption of property companies, but as we wrote before, the majority of EU member states do not have such a tax-exempt regime. In this case, investors in the shares of such companies will not be willing - ceteris paribus - to pay exactly the asset value of the property company, as the double layer of taxation makes the company less valuable than its assets. This may lead to a firm valuation on the stock exchange that is lower than the total value of real assets minus debt. In property market parlance, such a company would trade at a discount to Net Asset Value (NAV).

In the academic literature, there are a number of studies that investigate the discount-to-NAV issue and most of these consistently find that taxation is a major explanatory variable. Barkham and Ward (1999) study a set of thirty listed U.K. property companies for the years 1993 through 1995. During this period, the REIT-structure was not yet implemented. Their results show statistically significant relations between discounts and the capital gains tax, historic stock returns, company size and liquidity.Taxes and size increase the discount while high returns and liquidity decrease it. Furthermore, in a study of international property company discounts, Bond and Shilling (2003) investigate discounts to Net Asset Values for a set of 50 European listed property companies.As explanatory variables, they look at corporate structure and liquidity.They find that European property share markets with a tax transparent property investment vehicle in place or announced show substantially smaller discounts to net asset values than markets without a tax transparent structure. The findings suggest that tax transparent vehicles are priced more like their underlying real estate investments than tax paying vehicles.

In other words, property companies that pay corporate tax are structurally undervalued, which partly nullifies the benefits they have for investors. As a result, these investors are forced to invest through direct holdings, which is generally less efficient, especially for international property investments. 


\section{(ii) Corporate real estate}

The market size of the EU's institutional property market may be impressive, but it is far exceeded by corporate real estate holdings. For example, Krumm and Linneman (2001) estimated the value of Dutch corporate real estate holdings to be approximately $\$ 220$ billion, whereas the real estate portfolios of Dutch institutional investors amount to less than a third of this value. According to these authors, one of the prime reasons for the magnitude of these corporate portfolios has been the absence of well-developed commercial real estate markets and therefore, most of the European companies used to have no other choice but to own their land and buildings. Indeed, according to a study by DTZ (2003) approximately $70 \%$ of European businesses are owner-occupiers. In contrast, the equivalent figure for U.S. firms is only $30 \%$. The same report estimates the total value of corporate real estate in Germany, France and the United Kingdom at approximately $€ 1,000$ billion, $€ 700$ billion and $€ 710$ billion, respectively. By comparison, IPD (2003) estimates the total combined market capitalization of the institutional property portfolio in these countries at $€ 117$ billion, $€ 92$ billion and $€ 226$ billion, respectively.The magnitude of corporate real estate assets is such that the costs associated with owning these properties have become second only to payroll costs in many organizations (Veale 1989).

In the last decade, however, executives seem to have been rediscovering their property assets and have looked at them more critically. As a result, more and more firms have opted for corporate leases, which decrease the capital burden and enhance corporate flexibility. Glascock, Davidson and Sirmans $(1989,1991)$ and Myer, He and Webb $(1992)$ use an event study methodology to analyze market reactions to the announcements of corporate real estate divestures. Both studies find a positive abnormal return, which suggests that stockholders appear to benefit when companies sell their properties. Slovin, Sushka and Polonchek (1990) and Rutherford (1990) also document positive price reactions to the announcement of sale-and-leasebacks of real estate. These event studies all indicate that stockholders appreciate management efforts to restructure their business real estate. Brounen and Eichholtz (2005), investigating over 5,000 companies worldwide, find a generally negative relation between real estate ownership and risk-adjusted stock performance.

For corporations with a significant amount of corporate real estate, there are several reasons for a sell-off. First, it improves the capital structure; increasing the capital ratio makes it possible to borrow funds at more favourable conditions. Additionally, a more efficient financing structure permits a more effective allocation of the financial resources to the core business of the company, as less capital is tied to corporate real estate investments. Third, a spin-off of corporate real estate potentially leads to cost savings through more efficient use of real estate, and thus to increasing returns.

A main factor driving the potential for corporate real estate sell-offs is the availability of institutional capital to acquire the assets. While capital availability is not a problem in itself, the REIT structure is the most efficient way to channel capital into the current corporate real estate markets. It can be used to securitize the real estate assets and to obtain equity from the capital market, as has happened on a large scale in the United States. One pan-European REIT structure would facilitate companies with the possibility to pool properties in different geographic areas into a property investment company, thereby obtaining sufficient scale. With real estate assets divested and less capital tied up in fixed assets, companies can focus on their core business. This would aid the ongoing drive for more economic efficiency in Europe's corporations. 


\section{III.6 Market Safety and Security}

The lack of an EU REIT structure is detrimental to the stability of Europe's property markets in four ways. To start with, property companies have an incentive to incur a high level of debt in countries that do not have a REIT structure in place, since these companies can use the interest rate expense to reduce their tax bill. Property companies in these countries are likely to have a higher level of debt, thereby decreasing the security of the local property markets. The current crisis in the American mortgage market illustrates how dangerous excessive debt in the property markets can be for the stability of the financial markets.

To find out whether a leverage effect indeed exists, we perform a small event study. We investigate the capital structure of a number of leading property companies in the years just before and just after the REIT regime was introduced in their home countries. We do this for Belgium, Canada and France. Since the introduction of the REIT regime removes the incentive for high debt levels, we expect that the debt ratio of these property companies will fall once the property companies opt for the REIT status. Exhibit 17, which presents the average debt ratio before and after the introduction of the REIT structure, clearly shows that the level of debt goes down substantially after a REIT structure is introduced. Before the creation of the REIT regime, the average debt ratio varies between $50 \%$ and $60 \%$, but that ratio starts going down in the year of introduction and stabilizes at $20 \%$ just three years later.There can be no doubt that this lower leverage has a stabilizing effect on the performance of property companies, and likely also on the financial stability of the property market in general.

A second market safety effect associated with the REIT structure is the potential for increased international diversification across property markets in EU member states. In Section III.4, we already showed the diversification effects for international commercial property investments, but that effect is at least as strong for housing markets. Exhibit 18 shows the international correlations across national housing markets, based on quarterly housing market returns from January 1980 through December 2006. The correlations between the markets are very low, which implies that private and institutional investors can strongly benefit from international diversification across residential property markets, as it reduces portfolio risk. An EU REIT structure will facilitate investors from small and large member states to invest in residential real estate across the European Union.

Third, REITs face an obligatory payout of $90 \%$ of net earnings. Therefore, REITs have to turn to the capital market to obtain funding for acquisitions, which implies that REIT managers are frequently subject to the scrutiny of external agents (i.e. banks and investors). This reduces the conflict of interest between managers and shareholders. Bauer, Eichholtz and Kok (2007) indeed show that the restricted institutional setting in which REITs operate, mitigates the need for strong firm-level corporate governance. We expect that the introduction of an EU REIT structure will lead to an increase in the number of REITs, especially in member states that do not have a REIT structure yet.This is beneficial for the protection of small and large shareholders, and thereby increases market safety.

Fourth, the introduction of an EU REIT structure is likely to diminish the use of tax havens as jurisdiction of incorporation. In the next chapter, we will elaborate on the details of this phenomenon. Here, it suffices to note that property companies incorporated in tax havens face less scrutiny of financial regulators and the opaqueness of these property investment companies is likely to lead to increased governance problems. For instance, property com- 
panies incorporated in tax havens are usually externally managed and capital is frequently raised in a so-called blind pool, i.e. there is no investment property portfolio in place, but the money raised will be used to create it. Therefore, property investors do not face a level of protection similar to that of their colleagues who are active in markets where financial regulation is strong. 


\section{Policy Options: Zero Is not an Option}

Without the introduction of an EU REIT, all the problems discussed in Chapter III will remain. It will probably lead to an increasing number of REIT-like regimes in Europe, all with their own specific rules and regulations. The patchwork of regimes - as illustrated in Exhibits 5 through 11 - decreases transparency for investors, limits sector specialization by property companies, limits cross-border property diversification for EU property companies and leads to inefficient allocation of capital. This leads to unequal investment opportunities for both retail investors and institutional investors.

Furthermore, the absence of a REIT regime in a country does not necessarily mean that the government will receive corporate taxes. Initiators of property companies are increasingly looking to avoid double taxation by resorting to tax havens. The current situation has fostered a distinctive trend towards incorporation of property companies in tax havens, while investing via local subsidiaries and listing on for example the Alternative Investment Market (AIM) in London. Besides avoiding taxation, these vehicles face less regulation and supervision than property companies incorporated in EU countries.

Over the past few years, large numbers of property companies have set up base in tax-friendly legal jurisdictions, such as Jersey, Guernsey and the Isle-of-Man, mainly in the absence of tax-exempt property vehicles in the home country.The property companies can elect only to be taxable on local source income, meaning that they pay no tax in for example Jersey on income from elsewhere. While local taxation in the country of investment might at first instance seem like a problem, these taxes can be managed by purchasing through local (or Luxembourg) subsidiaries, which are funded with internal and external debt to offset taxes on rental income. Furthermore, avoiding local withholding tax rules can usually be achieved through the use of intermediate holding structures established in third countries, for example the Netherlands or Luxembourg.

To illustrate this structure, Exhibit 19 shows an example of the corporate structure of an existing property company. Real estate assets in Spain are bought via a local holding company, whereas real estate assets in France are bought via a Special Purpose Vehicle (SPV) that is owned by a holding company based in Belgium. The latter was especially useful before 2003 , when France did not have a REIT structure. The local tax on rental income in Spain and France can be offset by interest payments on the debt that is held by the holding companies. The holding companies transfer profits to a holding company in Luxembourg and can avoid paying withholding tax, due to the tax treaties between Luxembourg, France and Spain. Finally, the profits are transferred to the parent company in Guernsey, which distributes profits to investors without any corporate or withholding tax.As the outlined structure might be prone to be addressed by future EU tax regulations, an alternative to incorporation in tax havens is incorporation in Luxembourg. Many major property companies investing across Europe already use Luxembourg holding structures. The local tax regime is conducive to holding structures and Luxembourg has an extensive tax treaty network that helps avoiding double taxation.

Investing in property companies based on the Channel Islands or in Luxembourg is appealing to investors, due to the very low tax rates. Moreover these property companies can easily attract capital from the private market by listing on the lightly regulated Alternative 
Investment Market (AIM) of the London Stock Exchange. Exhibit 20 shows all the Initial Public Offerings (IPOs) by European property companies from January 2005 to June 2007, and how these are divided over the various European stock exchanges. Clearly, listing on the AIM is rather popular, both in number of IPOs and in terms of absolute size. Besides a fair number of listings on the main market of the London Stock Exchange, the markets in Frankfurt, Madrid and Paris also had some large initial public offerings, but not comparable in any measure to the AIM. The reason for the popularity of listing on the AIM is mainly its flexible approach to regulation: it does not have minimum requirements for company size, track record, the number of shares in public hands, prior shareholder approval, and the company's market capitalization. These characteristics make the AIM especially attractive for foreign companies and investors.

We note that initial public offerings of listed property companies in continental Europe mostly take place on the exchange of the country of incorporation. That is, French property companies list on the Paris stock exchange, German companies list on the Frankfurt stock exchange, and so on. However, Exhibit 21 shows that 41 out of the total 140 property company IPOs are by companies that are incorporated in a tax haven. This corresponds to $29 \%$ of the total number of IPOs. When we look at the share of tax haven-based IPOs in terms of total equity raised, this share even increases to $44 \%$, with Isle-of-Man and Guernsey-incorporated property companies representing the main contributors. In other words, especially the larger property companies use these routes.

In Panel B of Exhibit 21, we show the distribution IPOs of property companies incorporated in tax havens over time, both in terms of (relative) number and in terms of (relative) value. We cannot observe a clear pattern over time, but the data show that in all quarters of the sample period IPOs of property companies incorporated in tax havens take place.

To get some more insight into the IPOs on the AIM, Exhibit 22 shows the details of all 59 property companies listing on the AIM for the period from January 2005 to June 2007. Property companies incorporated in a country different than the United Kingdom make up more than $75 \%$ of total IPOs. In particular, Guernsey, Jersey and Isle-of-Man together make up more than half of all property company IPOs. Moreover, the main investment focus of newly listed companies is not the United Kingdom, in which only $25 \%$ of the newly listed property companies invest, but rather Central Europe: over $42 \%$ of the property companies with an initial public offering on the AIM have a geographical investment focus that is primarily Central European. In this geographic area, only Bulgaria has a REIT-structure, and Poland has a legal structure that is REIT-like. We cannot test empirically whether there is a relation between the lack of a REIT structure in Central Europe and the incorporation in tax havens by property companies that invest in that region, but we can state that the data clearly point in that direction.

An often-voiced criticism of one common EU REIT structure is the loss of tax revenues for EU member states, but this chapter suggests that this tax revenue is not likely to be very big to begin with.The market has already found ways to avoid double taxation. And whereas an EU REIT at least offers the opportunity of legally regulating tax issues and implementing proper supervision for investor protection, the current situation offers no such opportunity.

Moreover, the possibility of avoiding taxes and the ease of investing make property companies incorporated in tax havens highly interesting for investors, but the opaqueness of these 
property investment companies is likely to lead to increased governance problems. To begin with, the property companies thus created are mostly externally rather than internally managed. In other words, the management company and the property company are separated, preventing the investors in the property company from holding a stake in its management. This clearly creates conflict of interest, and an incentive to raise fees. Indeed, it has been welldocumented in the academic literature that externally managed funds underperform internally managed funds, charge higher fees, and are less transparent. This opaqueness is made worse because of the fact that much of the property capital raised through tax havens is for so-called blind pools, i.e. there is no investment property portfolio in place, but the money raised will be used to create it. In other words, investors invest in a plan, rather than a rentgenerating portfolio, which increases the risk profile of the investment.

The question is, of course, whether the introduction of an EU REIT regime will diminish the use of tax havens by property companies. We think this is indeed likely to happen, for four reasons. First, we currently observe that especially in countries without a REIT-structure in place, property investments are pooled and securitized via property companies incorporated in tax havens. So, companies that invest in French real estate are generally incorporated in France and tax-exempt under the SIIC regime, companies that invest in Dutch real estate are incorporated in the Netherlands and tax-exempt under the REIT regime, and so on. However, much of the capital raised through the London AIM is destined for Central Europe, where only Bulgaria and Poland have a tax-transparent property company regime. As the universe of institutional-grade real estate is still relatively small in most member states in Central Europe and the amount of institutional capital available is limited, the design and implementation of a national REIT regime may not seem worth the effort. In case of an EU REIT regime, local property companies of EU member states that currently have no REIT regime would not have to incorporate in tax havens, but could do that in their home country, allowing their shareholders to participate in Central European property portfolios without double taxation.

Second, it is a hassle for companies to set up the headquarters in a place other than the investment location. Unless a company resorts to external management, which has been shown to be detrimental to performance, the management of a property company should move to a tax haven if it is incorporated in one, leading to human resource issues and the separation of operations and management. For real estate investors, local market information is crucial for performance, so it is extremely important for management to be locally present. If an EU REIT were in place, top management of property companies in the EU could locate close to the markets where the capital is invested.

Third, especially for institutional investors, with an increasingly demanding and engaged customer base, transparency and credibility of investments is crucial. Corporate governance has become a major concern. Companies that are incorporated in tax havens generally have an image problem in this respect. Therefore, the demand side could act as a push factor when property companies decide whether or not to incorporate in a tax haven.

Fourth, even when property companies are incorporated in tax havens, the rental revenues of local operations are taxed.As we showed in Exhibit 19, the local tax can be offset against interest expenses on the debt of the local subsidiary and tax on net income can be avoided via tax treaties. However, this is obviously not an optimal corporate structure, both from an operational and from a transparency point-of-view.An EU REIT could directly target the local taxation and withholding taxation issues. In this way, tax revenues are distributed fairly over 
member states without double taxation of property companies. For investors, there would no longer be a reason to invest in property companies via tax havens.

To conclude, we would not recommend inaction on the EU REIT front. The status quo is not a satisfactory situation, as it would perpetuate the current fragmented market for property companies in the EU.This would continue to prevent property companies from specializing in property products, and would make it more difficult to reap advantages of scale and scope. From the point of view of tax collection, the status quo may seem tempting at first sight, but the market has already found ways around double taxation by making use of tax havens. Introducing an EU REIT would likely stop that, as it enables non-discriminatory regulation regarding withholding taxation for investors in all member states. This will allow regulators to create a unified and efficient regime for property companies. What that regime should look like exactly is the issue we will address in the next chapter. 


\section{The Preferred Structure for the EU REIT}

As we saw in Chapters II and III, national property share regimes in the EU vary considerably. Different governments have created very different regimes, probably for good reasons from their perspective, but creating a fragmented EU property share market in the process. The requirements regarding investments, operations, financing, and shareholders differ so much across countries that one cannot help getting a feeling of randomness. Moreover, legislation of property companies all over the EU is in flux. Most of the countries that have a special regime have created it in the last five years, and have tended to change it quite frequently after introduction. Countries without a special regime discuss the merits of introducing one.The EU currently lacks a common standard towards which all these national initiatives could evolve.

However, we do not think that 'anything goes' when it comes to tax-exempt property regimes. Some structures are clearly preferable to others, and the academic literature provides ample arguments to support these preferences. Based on a survey of that literature, this chapter will first discuss how an EU REIT should be structured in terms of governance and operational requirements. A second key issue here is whether the structure should be closed- or open-ended.

\section{V.1 Governance Issues and Additional Requirements}

The current REIT-like regimes in Europe are all characterized by a different set of requirements regarding operations, dividend payout, and ownership structure. For a European REIT structure to be successful, we argue that the requirements should be streamlined and minimized where possible. Below, we provide an outline of the ideal governance structure and operational requirements for an EU REIT, based on existing academic evidence.

\section{(i) Cash distribution requirement}

One of the strong features of the REIT structure is the obligatory payout of net earnings. This measure was originally implemented to ensure sufficient tax income through taxation of profits at the shareholder level, but the payout obligation benefits the minimization of agency problems in an important way. Under the traditional agency hypothesis, a conflict of interest arises between shareholders and managers due to differences in investment horizon, the tendency to empire building and risk-aversion of managers. The major issue underlying the agency hypothesis is too much free cash flow in the hands of managers, the so-called free cash flow problem (Jensen 1986). However, the tax-exempt status of REITs comes with an obligation to pay out most of the free cash flow to shareholders. Bauer, Eichholtz and Kok (2007) argue that this obligatory payout of net earnings reduces the conflict of interest between managers of property companies and investors in property companies. This is in line with the substitution hypothesis (Ghosh and Sirmans 2006, Hu and Kumar 2004, John and Knyazeva 2006).

The strong institutional setting that is created by the REIT structure even seems to reduce the need for traditional corporate governance mechanisms, as the relation between corporate governance and performance that has been widely documented in the finance literature (Brown and Caylor 2006, Core, Guay and Rusticus 2006, Durnev and Kim 2005, Gompers, 
Ishii and Metrick 2003, Klapper and Love 2004), does not seem to hold for U.S. REITs (Bauer, Eichholtz and Kok 2007).

The obligatory payout of net earnings has another important implication for the traditional agency problem: it forces REITs to turn frequently to the capital market in order to obtain funding, as organic growth through retained earnings is limited. These trips to the capital market lead to increased scrutiny by external agents, such as investment banks, underwriters, ratings agencies, and - most importantly - new investors (Easterbrook 1984). This reduces information asymmetries between management and shareholders, and therefore further limits agency problems.

Several studies find that the actual dividend payout of net earnings is substantially higher than the required percentage. For example, Wang, Erickson and Gau (1993) document - for a sample of 123 U.S. REITs - an average dividend payout ratio of $165 \%$, whereas the obligatory payout ratio was $95 \%$ at the time of the analysis. More recently, Feng, Ghosh and Sirmans (2007) and Ghosh and Sirmans (2006) find an average payout ratio of $144 \%$ of net earnings, also for U.S. REITs. The main driver of the higher-than-required dividend payout is the presence of strong internal governance mechanisms.

Currently, the payout obligation under the different REIT-like regimes in Europe varies between $0 \%$ and $100 \%$, with different treatment of rental income and capital gains. Due to the favourable corporate governance effects and to ensure ultimate tax payment, we advise an obligatory payout of net earnings between $80 \%$ and $100 \%$, with equal treatment of earnings from rental income and earnings from capital gains. This also ensures that an EU REIT will be a high-yield investment vehicle, and guarantees taxation at the investor level. However, even though the payout obligation strongly reduces agency problems, it still leaves discretionary cash flows for property executives. That is why we now provide some recommendations regarding the ideal corporate governance structure of an EU REIT.

\section{(ii) Corporate governance structure}

Corporate governance mechanisms are devised to monitor managerial behaviour and to minimize agency problems. Over the past decade, most European countries have issued guidelines regarding corporate governance practices, especially following corporate scandals in Europe and the United States. For example, Germany has the 'Cromme Code' (2002), the United Kingdom has the 'Combined Code' (2003), and The Netherlands has 'Code Tabaksblatt' (2003). These guidelines specify 'best practices' in corporate governance for all public companies.

Specifically for real estate companies, industry associations such as the European Public Real Estate Association (EPRA) and the European Association for Investors in Non-listed Real Estate Vehicles (INREV) have issued specific corporate governance guidelines. Furthermore, some REIT-like regimes in EU member states have specific requirements regarding the corporate governance structure of property companies.

A major corporate governance issue in the creation of a European REIT is whether a property company should be internally or externally managed.As we discussed in Chapter IV, the current trend, in which property companies are incorporated in tax havens while investing in non-local markets, has lead to increased use of external management. In a recent equity research report, Citigroup reports that out of the 23 property companies listed on the Alter- 
native Investment Market in London during 2005 and 2006, only three were internally managed (Citigroup 2006). The trend towards external rather than internal management directly opposes the disappearance of externally managed property companies in the United States. Yet, academic evidence overwhelmingly shows that agency problems are largest in externally managed funds.

Howe and Shilling (1990) are among the first to study the issue of external management. They find that externally managed U.S. REITs experience negative abnormal returns over the period from 1973 through 1987. Before 1986, U.S. REITs were all externally managed, but a change in the United States' REIT law in that year allowed REITs to make their investment decisions internally and to do property management in-house. Using data from 1987 through 1992 and adjusting for differences in market risk, Cannon and Vogt (1995) find that REITs with internal management significantly outperform REITs that are externally managed. In a comprehensive study, Capozza and Seguin (2000) show that REITs managed by external advisors underperform internally managed REITs by an astonishing 7\% per year. Property-level cash flow yields are similar between the two managerial forms; but corporate-level expenses and especially interest expenses are responsible for lower levels of cash available to shareholders in externally advised REITs. The authors document that the higher interest expenses are due to both higher levels of debt and to higher debt yields for externally advised REITs. Obviously, compensating managers based on either assets under management or on property level cash flows creates incentives for managers to increase the asset base by issuing debt, even if the interest costs are unfavourable.

Hsieh and Sirmans (1991) investigate the issue of 'captive' REITs, which are property companies formed by a sponsor to serve the sponsor's financial needs; i.e. a company is spinning off property in a listed independent subsidiary to raise money, but maintains control over the assets. This is possible because the sponsor is the external advisor of the property company and often the property manager as well. Obviously this construction creates agency problems due to entrenchment, which might be detrimental to stock performance. Indeed, Hsieh and Sirmans find that non-captive REITs structurally outperform captive REITs over the period from 1968 through 1986.

Today, the vast majority of U.S. REITs manage their own real estate portfolios and are internally advised. Using a post-1986 sample,Ambrose and Linneman (2001) test the hypothesis that internally-advised REITs dominate externally-advised REITs, mainly due to the superior ability to resolve conflicts of interest between REIT management and shareholders of the former.The results confirm that externally advised REITs are responding to market pressure to conform to the performance standards set by newer, internally advised REITs.

In other words, the experiences of the U.S. REIT industry are a natural experiment to test the merits of external versus internal management for property companies. The results of this experiment show that internal management is the preferred choice, creating management incentives for strong share performance. Based on this solid and compelling academic evidence, we strongly advise internal management to be allowed for the EU REIT.

\section{(iii) Leverage restrictions}

In Exhibit 9, we provided an overview of the current restrictions on leverage under the different European REIT-like regimes. These restrictions vary from a maximum leverage ratio of 
25\% in Belgium, to no restrictions in France. The main argument for restricting leverage in property companies is to protect shareholders against the risk involved in high levels of debt. However, there are several reasons why a debt ceiling for REITs distorts competition rather than protects shareholders.

First, most tax-transparent property companies in the EU have to pay out between $80 \%$ and $100 \%$ of net earnings. Therefore, organic growth is limited and property companies have to rely on the capital market to expand.Although tax-deductibility does not apply to REITs and therefore provides no incentive to take on debt, funding choices are limited to debt and equity. The market timing theory predicts that in adverse market circumstances, equity offerings are suboptimal and companies will issue debt to obtain funding (Baker and Wurgler 2002). Moreover, when interest rates are low, taking on debt increases return on equity.As observed during the latest wave of takeovers and delistings in 2006 and 2007, property companies with restrictions on taking on debt are extremely vulnerable to takeovers. Therefore, restricting leverage might limit the competitiveness of these property companies, both in sluggish market circumstances and during times of low interest environments.

Second, from a more fundamental point of view, it is questionable whether it is the task of regulatory bodies to protect investors against high levels of debt. Why should investors in property companies that operate under a REIT regime be protected, whereas investors in corporations like Danone, Shell, and Daimler are not? Restrictions on leverage and favourable tax treatment are principally unrelated, despite the fact that the former are often introduced with the latter. If investors in property companies needed no leverage protection before the introduction of tax-transparency, then they surely don't need it afterwards either. Besides that, when citizens take on a mortgage to finance their house, they are also free to choose the level of leverage.

Taking a global perspective, the largest and most developed property share markets - the United States and Australia - have no leverage restrictions.As Feng, Ghosh and Sirmans (2007) show, this has not lead to excessive leverage. In their study on the capital structure of U.S. REITs over the 1992 - 2003 time period, they find an average debt ratio of $65 \%$. Moreover, they argue that debtholders serve as a substitute to alternative monitoring mechanisms, thereby reducing the agency problem.

To conclude, the arguments for adding leverage restrictions to a tax-transparent property share regime are weak, and the experience of the two largest REIT markets in the world shows that an absence of such restrictions has not lead to problems for shareholders. We therefore advise to implement no leverage restrictions in an EU REIT regime.

\section{(iv) Ownership requirements}

Under some REIT-like regimes in the EU and under U.S. REIT regulations, property companies are obliged to adhere to certain requirements regarding their ownership structure. For example, in the United States, REITs need to have at least 100 shareholders, with the five largest shareholders holding not more than 50 percent of the shares (institutional investors are exempted from the rule). Such rules were originally implemented to ensure that REITs were easily accessible to retail investors, but they have some negative implications in terms of corporate governance as the rules lead to dispersed ownership. This makes it more difficult for large blockholders to acquire ownership stakes, and for shareholders to form alliances to pose a takeover threat. Since hostile takeovers are very rare in the listed property sector, 
various American scholars have argued that this is evidence for a non-functioning market for corporate control (Allen and Sirmans 1987, Campbell, Ghosh and Sirmans 2005, Ghosh and Sirmans 2003, Ghosh and Sirmans 2005, Ghosh and Sirmans 2006).

We oppose the American view, as hostile takeovers are absent in non-REIT property share markets as well, and poorly performing property companies face a higher chance of being taken over than well-performing property companies (Eichholtz and Kok 2007). However, we agree that the requirements regarding ownership structure hinder the monitoring role of large shareholders and the possibility for such investors to diversify investments substantially into real estate. Ultimately, this is also an issue that concerns ordinary citizens, since these large institutional investors invest their (pension) savings.

Prior to the change of U.S. regulations regarding the holdings of REIT shares by institutional investors, these investors were underrepresented in REIT stocks relative to their holdings in the broader stock market (Ghosh, Nag and Sirmans 1997, Ling and Ryngaert 1997).Although ownership requirements restrict the ability of a few large blockholders to expropriate wealth from small outside shareholders, which might seem to benefit retail investors (Friday, Sirmans and Conover 1999), it also leads to diffused share ownership. As regulators in the United States realized in the 1990s, the shareholder restrictions on REITs obstructed institutional ownership of REIT shares and lead to negative effects due to hindering block holder monitoring. Therefore, regulations were changed in 1993. Institutional investors were no longer treated as a single investor, but rather as an investor representing numerous individual investors. Starting with that change in REIT regulation, U.S. REITs attracted more institutional investors (Chan, Leung and Wang 1998). This is also beneficial to retail investors, as Wang, Erickson and Chang (1995) and Ghosh and Sirmans (2003) show that the participation of institutional investors increases the control and monitoring ability of shareholders, thereby increasing the value of REIT stocks. In 2007, following the revision of its REIT-legislation, the Netherlands followed the U.S. example and got rid of any shareholder requirements that previously applied.

In sum, the academic literature firmly shows that restrictions regarding the ownership structure of a REIT are not a good idea.This is underlined by the fact that the two countries with the longest experience with tax-transparency have both abolished the previously existing restrictions in this regard. We therefore advise to apply no shareholder restrictions to an EU REIT regime.

\section{(v) Mandatory listing}

Another shareholder issue is whether or not to require mandatory listing. Of the $13 \mathrm{EU}$ member states with a tax-transparent property company regime, six require that the stocks of these companies be listed on a stock exchange. While this may be good for the liquidity of these shares, it is doubtful whether there should be rules prescribing listing.

Again, the long experience with REIT structures of the Netherlands and the United States can provide some guidance.The regimes in neither of these countries require mandatory listing, and listed and unlisted REITs have been coexisting peacefully. Indeed, companies may and do alter their status in this regard, opting for a listing when market circumstances make this wise, and delisting in times when that is the better choice. For example, the cost of equity financing in the stock market was relatively low from 2004 through the first half of 2007 , and 
as a result, stock market listings of property companies were quite common, as Exhibit 2 already showed. This situation is not likely to continue forever, though, and at some point delisting will probably be a good idea again. As we showed for the case of restrictions on leverage, market timing theory (Baker and Wurgler 2006) suggests that companies should themselves decide how they should be financed. Mandatory listing goes against this, as it limits flexibility.An EU REIT regime should therefore not prescribe it.

\section{(vi) Operational restrictions}

In Exhibit 8, we showed the patchwork of operational restrictions that currently apply under the different REIT-like regimes in Europe.The restrictions can be classified as restrictions on diversification, restrictions on development and trading and restrictions on assets, and are mainly put in place to prevent property investment companies from 'active' and risky operations. However, limiting managers of property companies in executing an optimal strategy can have some detrimental side-effects, whatever that optimal strategy is. Campbell, Ghosh and Sirmans (2001), Ghosh and Sirmans (2003), and Whidbee (1997) argue that restrictions on assets limit the managerial experience of REIT managers, thereby precluding them from learning from other markets and assets.

Let us briefly discuss each of these types of restrictions, starting with requirements regarding diversification. Such requirements do not have a very solid basis in the academic literature. There is no discussion concerning the benefits of diversification: these benefits are substantial.The question is, however, at what level that diversification should take place. More specifically, should corporations diversify, or should their shareholders do so? This question has been studied by a great number of financial economists, both for corporations in general and for property companies. The abundant evidence indicates that shareholders should diversify, while companies should focus. In other words, diversification requirements for property companies go against a solid body of academic evidence. Moreover, the question arises why tax-transparent property companies should have diversification prescriptions, where other companies do not, including tax-paying property companies. It is hard to argue that investors in the former need more protection than those in the latter.

Secondly, trading and development are often restricted for tax-transparent property companies lest they lose their corporate tax exemption. There is no good economic reason for restricting trading and development by tax-transparent property companies. Indeed, Brounen and Eichholtz (2004) show that the combination of property development and investment is value-enhancing. Of course, there is the need to create a level playing field between such developing tax-exempt property investment companies and 'pure' developers, who pay corporate tax.This level playing field can also be accomplished by allowing such activities, and taxing them under the prevailing corporate tax regime.After a prolonged discussion between the Dutch tax authorities and the Dutch property industry this is exactly the format chosen in the current Dutch REIT legislation - property development is allowed in a separate taxed entity. In the United Kingdom, regulation regarding property development in REITs also aligns property investment companies with 'pure' property developers. Development is only tax-exempt for a UK REIT if the property is developed for the purpose of generating future rental income, i.e. if it adds to the property investment portfolio. If the property is developed with the explicit purpose to sell or if it is sold within three years of completion, the sale is taxed under normal corporate tax rules. This creates a level playing field with pure developers, since these only pay corporate tax when the development profit is realized. 
Third, tax-transparent property company regimes are often associated with restrictions on the asset base. Exhibit 8 suggests that limitations regarding liquid securities are quite popular among regulators, and so is the demand to invest at least a certain percentage of capital in real estate.The usefulness of these requirements is doubtful, however, since it is unlikely that the government is in a good position to take over the role of the investor when making strategic investment decisions. If a property company's investment policy and execution are transparent, than the potential purchasers of its shares will be able to make well-informed investments. There is no need for additional protection, especially since the (European) market for property companies is getting increasingly transparent, with an army of analysts, financial reporters, researchers, and consultants following this market quite closely.

Rather than restricting managerial behaviour and limiting investment opportunities, we would recommend to stimulate the use of strong internal monitoring mechanisms in an EU REIT and to compensate REIT executives for performance. Eichholtz, Kok and Otten (2007) study executive compensation practices in U.K. property companies and demonstrate that the strongest alignment between managers and shareholders is via executive shareholdings in the company. This view is supported by Han (2006), who shows for a sample of U.S. REITs that insider holdings are positively related to REIT value, although this relation is nonlinear. Furthermore, in line with most corporate governance directions, we recommend a board of directors with sufficient non-executive outside directors and a separated position for chairman and chief executive, as it has been well-documented in the literature that both enhance performance (Agrawal and Knoeber 1996, Friday and Sirmans 1998, Subrahmanyam and Rangan 1997).

\section{V.2 Open versus Closed-Ended Structures}

In the early REIT days, property companies in the Netherlands and Australia used to have an open-ended structure. Under this structure, investors are allowed to buy or redeem shares from the property company at any given point in time. Major advantages for investors are high liquidity and low volatility of returns. The issue price of open-ended companies is calculated on the basis of the net asset value, plus an offering charge, which is usually $5 \%$. The net asset value is calculated by estimating the actual market value of all assets held by the company, less all liabilities, divided by the number of issued shares.

Although most assets owned by property companies are usually properties, they often also own some liquid assets like the shares of other property companies or money market instruments. Establishing the market values of these latter assets is quite easy, as real time market price information is usually available for them. However, for the property portfolio, this is not the case, making accurate daily pricing very difficult. Even the use of independent experts does not completely solve this problem.

There is a solid body of academic knowledge investigating just how hard it is to generate accurate and timely value of properties. Most importantly, property valuations suffer from smoothing and lagging, caused by backward-looking behaviour of appraisers. This leads to differences between true prices and appraisal-based values, especially in terms of volatility and mean return (Geltner 1991, Quan and Quigley 1991, Young and Graff 1995).

As buildings are only sold infrequently, lagging occurs because the current value of property cannot be directly observed in the market. Property appraisals do therefore not reflect 'true' 
prices. Smoothing occurs when property appraisers use old information in a new appraisal: if this occurs consistently, the price development will be very smooth, and thus the volatility of returns will be artificially low. Clayton, Geltner and Hamilton (2001) find evidence that property appraisers give weight to previous appraised values (or old market information), and this weight varies with the quantity and quality of information available to the appraiser. In case of uncertainty about new information, property appraisers tend to rely more on older data used in previous appraisal reports, or, even worse, on those reports directly.

The experience with open-ended structures in the Netherlands and Australia illustrates these valuation difficulties, and shows what can go wrong as a result. The listed property share market in both countries went through a severe crisis, after which they switched to the closed-ended structure.

In the case of the Netherlands, a global property market crisis, to which the self-determined net asset value of the open-ended property companies had not fully adjusted, caused a high outflow of capital from these companies in late 1989 and early 1990. In that period, the largest and most pre-eminent Dutch property company was Rodamco.As an illustration, we show the development of Rodamco's share performance in Exhibit 23. During the 1980s, Rodamco had been among the largest property companies in the world, mainly investing in Europe and North America. The global real estate crisis was felt in all its main investment markets.

This should have had an adverse impact on Rodamco's share price, but Rodamco did not adequately adjust its share price to the new market circumstances. However, as standard valuation rules prescribed a yearly mass appraisal at the end of the fiscal year, investors were able to predict that the redemption price was going to suffer a severe decline at the end of the year.This arbitrage opportunity led to a massive capital outflow. During the first nine months of 1990, Rodamco was forced to buy $20 \%$ of its own shares for a total amount of 2.3 billion guilders, 0.8 billion of which were spent in August and September alone. By the end of September the cash position had all but dried up. At Sunday September $23^{\text {rd }}$, Rodamco announced that it would stop buying its own shares.The semi-open-ended structure was cancelled.The graph in Exhibit 23 clearly shows the straight-line performance of Rodamco's shares prior to 1990, and the very sharp drop after the company was forced to terminate the open-ended regime.

A similar crisis occurred at about the same time in the Australian open-ended property market. In particular after the stock market crash of 1987, which caused a strong increase in property prices, the Australian real estate market saw huge inflows of capital.This surge was supported even further by the credit policy of Australian banks, which gave out loans collateralized by real estate at exceptionally low interest rates. When the central bank tightened monetary policy, property prices dropped by around $60 \%$. This, in turn, caused a run by investors in order to redeem their shares of open-ended real estate funds. To avoid a collapse of those investment vehicles, the government decided to stop all redemptions for a period of 12 months and forced all funds to list on the stock exchange.

These two examples illustrate the key weakness of the open-ended property share regime: effectively, such a regime amounts to the financing of an illiquid asset with equity that is callable on a daily basis. When things go smoothly in the property market, this may work well, but when the markets go down, as they inevitably will do from time to time, the openended structure is a recipe for disaster. 
A second major caveat of open-ended property funds is the fact that they may be marketed as real estate investments, whereas a major part of the underlying assets does not consist of real estate investment at all. Exhibit 24 shows the asset composition of a sample of German open-end property funds as of June 2007. On average, $28 \%$ of total assets are invested in liquid assets. Before 2005 , the funds held on average $25 \%$ to $49 \%$ of their assets in cash or bonds. This high allocation to cash does not really help performance.

Exhibit 25 shows the average share performance of the German open-ended funds compared to European property share indices for the last 10 years. This comparison is relevant, since the German open-ended funds have invested considerable parts of their capital across Europe in this period.The graph illustrates the poor performance of the funds, especially during the last half of the decade: $\mathrm{a} € 100$ investment in German property funds would have been worth $€ 145$ today if all dividends would have been reinvested. The comparable number for EU property companies was approximately 220 or 250 , depending on the index used to make the comparison. The almost straight-line performance of the German funds suggests considerable smoothing in the appraisal process.

Nevertheless, this high allocation to liquid assets may be one of the reasons that Germany's open-ended real estate structure has survived for more than 50 years, despite their poor overall performance. Another reason may be found in the specific regulatory and institutional design of the German funds: funds can delay the repurchase of units for a period up to two years in case of high liquidity outflows. Furthermore, different elements of the investment practice and valuation process also improved funds' resilience against liquidity crises even if they were not initially implemented for that reason. One such element is the offering charge - usually 5\% - which becomes due when buying a share of an open-end real estate fund. Originally designated for covering distribution costs, these built-in transaction costs create an effective barrier, reducing the attractiveness of frequent transactions and thereby limit arbitrage opportunities. Due to the offering charge, the necessary investment horizon to achieve a positive return increases to at least one year on average. By the end of 2005, a total of 31 German open-ended property funds had more than EUR 85 billion assets under management - up from EUR 47 billion in 2000 - which amounts to $15.5 \%$ of total assets managed by German mutual funds.

However, in 2005 and 2006, the German open-ended funds experienced a crisis that closely resembled those in the Netherlands and Australia. After some years of lingering unrest, in which several attempts had been made to match the prices of the open-ended funds more closely to the market value of properties, Deutsche Bank Real Estate (now RREEF) closed Grundbesitz Invest, at that time worth $€ 6$.2bln. Closing the fund had become necessary as investors undertook a run on the fund when a downward revaluation seemed likely.The subsequent promise to compensate certain investors for the financial loss made the public outcry even stronger. Shortly after Deutsche Bank closed its open-end fund, another fund, KanAm Grundinvest, was downgraded by a rating agency. Soon, investors lost confidence in the openended property fund industry, leading to tremendous capital outflows.

Summarizing these international experiences, the open-ended structure for real estate companies has not been successful, and does not seem a sustainable structure in the long run. When crisis hits the property markets, which will inevitably happen now and then, the inherent flaws of the open-ended structure become apparent, causing serious instability and loss of investor confidence in the market. Therefore, the EU REIT should be closed-ended. 


\section{Concluding Remarks}

This study has provided an in-depth analysis of the listed property sector in Europe, and of the detrimental effects current legislation has on this sector.The scope and method of analysis of this report is financial-economic. It is based on a thorough survey of the relevant academic literature, and adds additional empirical analysis where necessary and possible.

The report first takes stock of the current situation in the global property share market.This market has grown considerably in the last decades, making property holdings through listed property companies an important alternative to direct real estate investment. The global property share market now has an approximate market value of $€ 1.2$ trillion, and Europe's share in this market is approximately $25 \%$. Most countries that have a property share market also have a special regime for property companies, intended to avoid double taxation of rental income streams and creating a level playing field between direct real estate investment and investment through property companies. The United States has the longest experience with such a regime, and is the largest property share market operating under one and the same institutional regime. Compared to that, the EU property share market is a hodgepodge.

Of the $27 \mathrm{EU}$ member states, 13 have a tax-transparent regime for property companies. Most of these date from the last five years, and other countries are contemplating the introduction of their own regimes.The existing regimes differ greatly regarding operational and financing restrictions, corporate governance, and listing requirements. There is no common standard across the EU to which they conform. In principle, these differences do not need to be problematic, but the lack of a common EU property share regime creates national barriers that hamper international diversification. This is a problem for investors all member states, as they cannot achieve optimal diversification at home, and need international exposure to spread the risk of their property portfolios. The lack of an EU REIT also makes product specialization by property companies more difficult, while this would likely be good for performance, and could get the capital market involved in property sectors that have traditionally been in the realm of the public sector.

Without the introduction of an EU REIT, the market will stay fragmented, and all the problems associated with the current situation will continue. Moreover, the status quo does not imply that national governments in the EU will continue to receive corporate tax payments from property companies. The market has already found a way around this, by incorporating property companies in tax havens. Introduction of the EU REIT would likely turn this development around, also allowing better regulation and supervision than currently in the tax havens.

The EU REIT does not have to be created from scratch. Both in the EU and outside of it, there is a lot of experience with these regimes, and careful analysis of this experience provides direction towards an optimal pan-EU structure. Such a structure should be internally managed and closed-ended, without requirements regarding debt financing and public listing of the shares. There ought to be no restrictions regarding operations and assets, and development activities should be fully allowed, while maintaining a level playing field with 'pure' developers, who are taxed. If such a structure were introduced throughout the EU, Europe could create the largest and most efficient property capital market in the world. 


\section{Glossary}

Alpha (or $\alpha$ ): measure of risk-adjusted performance for stocks. A firm with positive alpha generates a stronger stock return than an investor could expect given its risk, and therefore creates added value. Likewise, a firm with negative alpha destroys shareholder value.The market as a whole has an alpha of exactly zero.

Alternative Investment Market (AIM): the London Stock Exchange's global market for smaller, growing companies, providing access to companies than would normally be admitted to public markets. Moreover, it offers a more flexible regulatory regime than a listing on the main market, access to a wide pool of capital for growing companies, enhanced profile and increased status and credibility.

Beta ( $\beta$ ): the measure for systemic risk, i.e. the risk of a company that is priced in the capital market.A company's return should be in line with its beta.

Blind Pool: the offering of investment opportunities in broadly specified property, which has yet to be acquired. The exact investment depends on the general partner, who chooses the property type and location, and assembles the investment package.

Cash Flow: a measure of cash inflow and outflow from a company. Positive cash flow means more money is coming into the business than is leaving it. Negative cash flow is the opposite. Cash flow is calculated by adding to profits any bookkeeping expenses that result in items being deducted but not paid out in cash to after-tax income. Such expenses include for example depreciation, depletion, amortization, and charges to reserves.

Closed-End Structure: a corporate structure in which a company has a constant number of shares outstanding. No shares are redeemed for cash or securities unless a company engages in a share-buyback programme. The only way an investor can acquire shares in a closedend fund is to buy existing shares from another investor on the secondary market - as opposed to an open-end structure where the company can issue new shares on a daily basis.

Correlation: the correlation coefficient is a statistical measure of the strength of the linear relation between two random variables, where the value 1 indicates variables that move perfectly in lockstep, a value of 0 indicates that two variables are completely independent, and a value of -1 indicates that two variables move exactly against each other. For investment portfolio management, the correlation is a measure for diversification, with maximum diversification benefits if the returns on two assets have a correlation coefficient of -1 .

Debt ratio: see 'Leverage'.

Development: real estate development involves building on land, thereby increasing the value of the land.The developer may be an individual, but is often a partnership or a corporation. The role of the developer in real estate is comparable to that of the producer in the film industry.

Direct Property Investment: ownership of real estate assets - buildings and land - either through outright ownership or through a legal entity in which the investor has full control. 
Diversification: in the case of a property company: the practice of spreading capital over several different property types or over several different geographic regions in order to reduce risk. In the case of an investor: the practice of spreading investments over different asset classes, or within one asset class, over different sectors or regions.

Equity: ownership interest in a property company in the form of common stock or preferred stock. It also refers to total assets minus total liabilities, in which case it is also referred to as shareholder's equity or net worth or book value. In direct real estate investments, it is the difference between what a property is worth and what the owner owes against that property (i.e. the difference between the property value and the remaining mortgage or loan value on a property).

External Management: a firm that is hired by for example a property investment company to manage the investments. Shareholders in the property company do not necessarily own the management company. Used to be common practice for U.S. REITs and is the opposite of internal management.

Herfindahl: a measure of concentration.A property company with a Herfindahl index close to 1 indicates that the company concentrates on one specific property type or geographic sector. A Herfindahl index that is close to 0 indicates that a property company diversifies investments over more than one specific property type or geographic sector.The Herfindahl is calculated by the sum of squares of the percentage invested in each property type or region.

Indirect Property Investment: ownership of real estate assets - buildings and land through a company in which the investor does not have full control.

Initial Public Offering (IPO): the first time a company's stock is available for public purchase - this can be on a stock exchange or via a private offering. Via an IPO, access is gained to a source of capital which did not previously exist.There are numerous reporting and compliance issues to deal with from this point forward which could involve a considerable expense. Stock that is publicly traded on an exchange provides the owner with an established price and a market in which to buy or sell.

Internal Management: indicates that a company has management of investments integrated in operations. Shareholders in the property company own the property portfolio as well as the management company. Opposed to external management, in which an outside firm is hired to manage the investments.

Leverage: the degree to which a property company is utilizing borrowed money. Companies that are highly leveraged may be at risk of bankruptcy if they are unable to make payments on their debt; they may also be unable to find new lenders in the future. There might be tax advantages associated with borrowing if interest payments are tax-deductible. Also called debt/equity ratio.

Market Capitalization: this is determined by the price of a stock multiplied by the number of shares the company has currently outstanding, i.e. it represents the total value of a firm's listed stock. 
Net Asset Value (NAV): the value of a company, calculated by the subtracting total liabilities from total assets. An often-used variation of this metric is NAV-per-share, calculated by dividing net asset value by the total number of shares outstanding.

Ordinary Least Squares (OLS) Regression: a mathematical optimization technique that is used to specify the relation between two or more variables. It attempts to find a best fit by minimizing the sum of the squares of the differences (called residuals) between the fitted function and the data.

Open-End Structure: a fund structure under which a company can issue and redeem shares at any time.The price per share, similar to the NAV-per-share, is calculated at the end of every trading day by dividing the company's assets minus liabilities by the number of shares outstanding.

Passive investment vehicle: a fund structure under which a company does not engage in any or limited operating activities. In case of real estate, a passive investment vehicle owns and manages real estate assets, such as buildings and land, but does not actively develop new properties.

R squared ( $\left.\mathbf{R}^{2}\right)$ : the $\mathrm{R}$ squared statistic represents the percentage of the dependent variable, in this case the fund's alpha that can be explained by the dependent variables. It's a statistic that measures the goodness of fit of a model.An R squared of 1 means that the fund's returns are completely explained by the dependent variables. Conversely, a low R-squared indicates that very few of the fund's returns are explained by the dependent variables.

Real Estate Investment Trust, or REIT: A REIT is a company which:

- has to derive the majority of its income from property investment

- pays no taxes at corporate level; however, a very high proportion of net earnings is paid out as dividends to shareholders who are then taxed

- has the option - but not necessarily the obligation - of public listing

- functions within a specific legislative framework and under supervision of authorities

Risk-adjusted stock performance: see 'Alpha'.

Significance: the significance level of a hypothesis test is the chance that the test erroneously rejects the null hypothesis when the null hypothesis is true.

Systematic Risk: also called market risk. Reflects the (macro-economic) risk that affects all companies in a certain stock market. This risk cannot be diversified away. It is measured by beta.

Total Return Index: is the performance measure of a stock. It calculates the performance of a single stock or a group of stocks, assuming that dividends are re-invested. For the purpose of index calculation, the value of the dividends is re-invested in the index on the ex-dividend date. 
$t$-statistic: a statistic used to test hypotheses. When the value of the test statistic is larger than specified for a specific significance level (i.e. $1 \%$ or $5 \%$ ), the null hypothesis can be rejected at the specified significance level.

Volatility: measure of risk for an investment; how much the price fluctuates over time. It is calculated by using standard deviation. High volatility corresponds with a high degree of risk. 


\section{Literature}

Agrawal,A., and C.R. Knoeber, 1996, Firm Performance and Mechanisms to Control Agency Problems Between Managers and Shareholders,Journal of Financial and Quantitative Analysis 31,377-397.

Allen, P.R., and C. F. Sirmans, 1987, An Analysis of Gains to Acquiring Firm's Shareholders:The Special Case of REITs, Journal of FInancial Economics 18, 175-184.

Ambrose, B.W., S.R. Ehrlich, W.T. Hughes, and S.M. Wachter, 2000, REIT Economies of Scale: Fact or Fiction?,Journal of Real Estate Finance \& Economics 20, 211-224.

Ambrose, B.W., M.J. Highfield, and P.D. Linneman, 2005, Real Estate and Economies of Scale: The Case of REITs, Real Estate Economics 33, 323-350.

Baker, M., and J.Wurgler, 2002, Market Timing and Capital Structure, Journal of Finance 57, $1-32$.

Barkham, R.J., and C.W.R.Ward, 1999, Investor Sentiment and Noise Trades: Discount to Net Asset Value in Listed Property Companies in the U.K., Journal of Real Estate Research $18,291-312$.

Bauer, R., P.M.A. Eichholtz, and N. Kok, 2007, Corporate Governance and Performance:The REIT Effect, Under review at Real Estate Economics.

Black, Bernard S., Hasung Jang, and Woochan Kim, 2006, Does Corporate Governance Predict Firms' Market Values? Evidence from Korea,Journal of Law, Economics, and Organization 22, 366-413.

Boer, Dick, Dirk Brounen, and Hans Op't Veld, 2005, Corporate Focus and Stock Performance: International Evidence from Listed Property Markets, Journal of Real Estate Finance and Economics 31, 263-81.

Bond, S.A., and J.D. Shilling, 2003, An Evaluation of Property Company Discounts in Europe, Working Paper University of Cambridge.

Brady, P.J., and M.E. Conlin, 2004, The Performance of REIT-owned Properties and the Impact of REIT Market Power,Journal of Real Estate Finance E Economics 28, 81-95.

Brounen, D., P.M.A. Eichholtz, and M.A.J.Theebe, 2007, Inflation Protection from Homewonership: Long-Run Evidence: 1814-2004, Working Paper.

Brounen, D., and M. ter Laak, 2005, Understanding the Discount: Evidence from European Property Shares, Journal of Real Estate Portfolio Management 11, 241-251.

Brounen, Dirk, and Piet M.A. Eichholtz, 2005, Corporate Real Estate Ownership Implications: International Performance Evidence, Journal of Real Estate Finance and Economics 30, $429-45$.

Brown, L.D., and M.L. Caylor, 2006, Corporate Governance and Firm Valuation, Journal of Accounting and Public Policy 25, 409-434. 
Campbell, R., C. Ghosh, and C. F. Sirmans, 2001,The Information Content of Method of Payment in Mergers: Evidence from Real Estate Investment Trusts (REITs), Real Estate Economics 360-387.

Campbell, R., C. Ghosh, and C. F. Sirmans, 2005, Value Creation and Governance Structure in REIT Mergers, Journal of Real Estate Finance \& Economics 31, 225-239.

Cannon, S.E., and S.C.Vogt, 1995, REITs and Their Management:An Analysis of Organizational Structure, Performance and Management Organization,Journal of Real Estate Research $10,297-317$.

Capozza, D.R., and P.J. Seguin, 1998, Managerial Style and Firm Value, Real Estate Economics 26, 131-150.

Capozza, D.R., and P.J. Seguin, 1999, Focus, Transparency and Value:The REIT Evidence, Real Estate Economics 27, 587-619.

Capozza, D.R., and P.J. Seguin, 2000, Debt, Agency, and Management Contract in REITs: The External Advisor Puzzle, Journal of Real Estate Finance E Economics 20,91-116.

Chan, S.H., W.K. Leung, and K. Wang, 1998, Institutional Investment in REITs: Evidence and Implications, Journal of Real Estate Research 16,357-374.

Citigroup, 2006, Real Estate IPOs: More to Come, in Citigroup Global Markets Equity Research, ed.

Clayton, J., D.M. Geltner, and S.W. Hamilton, 2001, Smoothing in Commercial Property Valuations: Evidence from Individual Appraisals, Real Estate Economics 29, 337-360.

Conover, C.M., H.S. Friday, and S. Howton, 1998, The Relationship between Size and Return for Foreign Real Estate Investments, Journal of Real Estate Portfolio Management 4, 107112.

Conover, C.M., H.S. Friday, and C. F. Sirmans, 2002, Diversification Benefits from Foreign Real Estate Investments, Journal of Real Estate Portfolio Management 8, 17-25.

Core, J.E., W.R. Guay, and T.O. Rusticus, 2006, Does Weak Governance Cause Weak Stock Returns? An Examination of Firm Operating Performance and Investors' Expectations, Journal of Finance 61, 655-87.

Cronqvist, H., P. Hogfeldt, and M. Nilsson, 2001, Why Agency Costs Explain Diversification Discounts, Real Estate Economics 29, 85-126.

De Roon, F.A.,T.E. Nijman, and B.J.M. Werker, 2001, Testin for Mean-Variance Spanning with Short Sales Constraints and Transaction Costs:The Case of Emerging Markets, Journal of Finance 56, 721-742.

Devaney, M., and W.L. Weber, 2005, Efficiency, Scale Economies, and the Risk/Return Performance of Real Estate Investment Trusts, Journal of Real Estate Finance \& Economics 31, 301-317.

DTZ, 2003, Money Into Property - Europe, (Amsterdam, the Netherlands). 
Durnev,A., and E.H. Kim, 2005, To Steal or Not to Steal: Firm Attributes, Legal Environment, and Valuation, Journal of Finance 60, 1461-1493.

Easterbrook, F., 1984, Two Agency-Cost Explanations of Dividends, American Economic Review 74, 650-659.

Eichholtz, P.M.A., 1996, Does International Diversification Work Better for Real Estate than for Stocks and Bonds, Financial Analyst Journal 52, 56-62.

Eichholtz, P.M.A., 1997, A Long Run House Price Index:The Herengracht Index, 1628-1973, Real Estate Economics 25, 175-192.

Eichholtz, P.M.A., M. Hoesli, and B.D. MacGregor, 1995, Real Estate Portfolio Diversification by Property Type and Region, Journal of Property Finance 6, 39-59.

Eichholtz, P.M.A., and N. Kok, 2007, How Does the Market for Corporate Control Function for Property Companies?, Forthcoming Journal of Real Estate Finance and Economics.

Eichholtz, P.M.A., N. Kok, and R. Otten, 2007, Executive Compensation in UK Property Companies, Journal of Real Estate Finance and Economics 36.

Eichholtz, P.M.A., N. Kok, and B.G.M.Wolnicki, 2007, Who Should Own Senior Housing?, Journal of Real Estate Portfolio Management 13, 205-218.

Eichholtz, P.M.A., H. Op 't Veld, and M. Schweitzer, 2000, REIT Performance: Does Managerial Specialization Pay?, in P. Harker, and S.Zenios, eds.: Performance of Financial Institutions (University Press, Cambridge).

Eichholtz, P.M.A., H. Op 't Veld, and S. Vestbirk, 1999, Going International: Liquidity and Pricing in the Largest Public Property Markets, Real Estate Finance Fall, 74-81.

Feng, Z., C. Ghosh, and C. F. Sirmans, 2007, CEO Involvement in Director Selection: Implications of REIT Dividend Policy, Forthcoming Journal of Real Estate Finance \& Economics.

Feng, Z., C. Ghosh, and C. F. Sirmans, 2007, On the Capital Structure of Real Estate Investment Trusts (REITs), Journal of Real Estate Finance E Economics 34, 81-105.

Fitzgerald,T., 2004, In Solitary, Commercial Property News 18, 23-25.

Friday, H.S., and C.F. Sirmans, 1998, Board of Director Monitoring and Firm Value in REITs, Journal of Real Estate Research 16,411-427.

Friday, H.S., G.S. Sirmans, and C.M. Conover, 1999, Ownership Structure and the Value of the Firm:The Case of REITs, Journal of Real Estate Research 17, 71-90.

Geltner, D.M., 1991, Smoothing in Appraisal-Based Returns, Journal of Real Estate Finance E Economics 4, 327-345.

Ghosh, C., R. Nag, and C. F. Sirmans, 1997, Wealth Effects of REIT Seasoned Equity Offerings., Center for Real Estate and Urban Studies WOkring Paper (University of Connecticut, Storrs, CT). 
Ghosh, C., and C. F. Sirmans, 2003, Board Independence, Ownership Structure and Performance: Evidence from Real Estate Investment Trusts, Journal of Real Estate Finance $\mathcal{E}$ Economics 26, 287-318.

Ghosh, C., and C. F. Sirmans, 2005, On REIT CEO Compensation: Does Board Structure Matter?,Journal of Real Estate Finance E Economics 30, 397-428.

Ghosh, C., and C. F. Sirmans, 2006, Do Managerial Motives Impact Dividend Decisions in REITs?,Journal of Real Estate Finance E Economics 32, 327-355.

Giliberto, S.M., and R.E. Hopkins, 1990, Metro Employment Trends: Analysis and Portfolio Considerations, in Inc. Salomon Brothers, ed.

Glascock, J., W. Davidson, and C. F. Sirmans, 1989, An Analysis of the Disposition and Acquisition of Real Estate Assets, Journal of Real Estate Research 4, 131-140.

Glascock,J.,W. Davidson, and C. F. Sirmans, 1991,The Gains From Corporate Selloffs: The Case of Real Estate Assets, AREUEA Journal 19, 567-582.

Glascock, J., and L.J. Kelly, 2007, The Relative Effect of Property Type and Country Factors in Reduction of Risk of Internationally Diversified Real Estate Portfolios, Journal of Real Estate Finance \& Economics 34, 369-384.

Goetzmann,W.N., and R.G. Ibbotson, 1990,The Performance of Real Estate as an Asset Class, Journal of Applied Corporate Finance 3, 65-76.

Gompers, P.A., J. Ishii, and A. Metrick, 2003, Corporate Governance and Equity Prices, Quarterly Journal of Economics 118, 107-155.

Grauer, R.R., and N.H. Hakansson, 1987, Gains from International Diversification: 1968 - 85 Returns on Portfolios of Stocks and Bonds, Journal of Finance 42, 721-739.

Han, B., 2006, Insider Ownership and Firm Value: Evidence From Real Estate Investment Trusts, Journal of Real Estate Finance \& Economics 32, 471-493.

Hartzell, D.J., D.G. Shulman, and C.H.Wurtzebach, 1987, Refining the Analysis of Regional Diversification for Income-Producing Real Estate, Journal of Real Estate Research 2, 8595.

Hopkins, R.E., and B.A.Testa, 1990, Economic Diversification in Real Estate Portfolios II, in Inc. Salomon Brothers, ed.

Howe, John S., and James D. Shilling, 1990, REIT Advisor Performance, American Real Estate and Urban Economics Association Journal 18, 479-500.

Hsieh, C., and C. F. Sirmans, 1991, REITs as Captive-Financing Affiliates: Impact on Financial Performance, Journal of Real Estate Research 6, 179-190.

Hu,A., and P. Kumar, 2004, Managerial Entrenchment and Payout Policy,Journal of Financial and Quantitative Analysis 39, 759-790.

IPD, 2003, IPD France Index 2002. 
IPD, 2003, IPD Germany Index 2002.

IPD, 2003, IPD United Kingdom Index 2002.

Jensen, M.C., 1986,Agency Costs of Free Cash Flow, Corporate Finance, and Takeovers, American Economic Review 76, 323-329.

John, K., and A. Knyazeva, 2006, Payout Policy,Agency Conflicts, and Corporate Governance, Working Paper (New Yoek University, New York).

Klapper, L.F., and I. Love, 2004, Corporate Governance, Investor Protection, and Performance in Emerging Markets, Journal of Corporate Finance 10, 703-728.

Krumm, P.J., and P. Linneman, 2001, Corporate Real Estate Management, Zell/Lurie Center Working Papers (Wharton).

Levy, H., and Z. Lerman, 1988, The Benefits of International Diversification in Bonds, Financial Analyst Journal 44, 56-64.

Lewis, D.,T.M. Springer, and R.I.Anderson, 2003, The Cost Efficiency of Real Estate Investment Trusts:An Analysis with a Bayesian Stochastic Frontier Model,Journal of Real Estate Finance E Economics 26, 65-80.

Ling, D.C., and M. Ryngaert, 1997, Valuation Uncertainty, Institutional Involvement, and the Underpricing of IPOs:The Case of REITs,Journal of FInancial Economics 43, 433-456.

Lizieri, C., P. McAllister, and C.W.R.Ward, 2003, Continental Shift? An Analysis of Convergence Trends in European Real Estate Equities, Journal of Real Estate Research 25, 1-22.

Markowitz, H., 1952, Portfolio Selection, Journal of Finance 7, 77-91.

Montgomery, C.A., 1974, The Measurement of Firm Diversification: Some New Empirical Evidence The Academy of Management Journal 25, 299-307.

Mueller, G.R., 1993, Refining Economic Diversification Strategies of Real Estate Portfolios, Journal of Real Estate Research 8, 55-68.

Myer, F.C., L. He, and J.R. Webb, 1992, Sell-Offs of U.S. Real Estate:The Effect of Domestic versus Foreign Buyers of Shareholder Wealth, AREUEA Journal 20, 487-500.

Nelson,A., 2007, Prospects for Student Housing Investment, (RREEF Research, San Francisco).

NIC/PriceWaterhouseCoopers, 2001, The Case for Investing in Seniors Housing and LongTerm Care Properties (With Updated Projections), (Annapolis, MD).

Quan, D.C., and J.M. Quigley, 1991, Price Formation and the Appraisal Function in Real Estate Markets, Journal of Real Estate Finance E Economics 4, 127-146.

Rutherford, R.C., 1990, Empirical Evidence on Shareholder Value and the Sale-Leaseback of Corporate Real Estate, AREUEA Journal 18, 522-529.

Shin, H.H., and R.M. Stulz, 2000, Firm Value, Risk, and Growth Opportunities, (NBER, Cambridge, MA, USA). 
Slovin, M.B., M.E. Sushka, and J.A. Polonchek, 1990, Corporate Sales-and-Leaseback and Shareholder Wealth, Journal of Finance 45, 289-299.

Solnik, B., and B. Noetzlin, 1982, Optimal International Asset Allocation, Journal of Portfolio Management 9, 11-21.

Subrahmanyam, V., and N. Rangan, 1997, The Role of Outside Directors in Bank Acquisitions, Financial Management 26, 23-36.

Veale, P., 1989, Managing Corporate Real Estate:Current Executive Attitudes and Prospects for an Emergent Management Discipline, Journal of Real Estate Research 4, 1-22.

Wang, K., J. Erickson, and G. Gau, 1993, Dividend Policies and Dividend Announcement Effects for Real Estate Investment Trusts, Real Estate Economics 21, 185-201.

Wang, K., J. Erickson, G. Gau, and S.H. Chan, 1995, Market Microstructure and Real Estate Returns, Real Estate Economics 23, 85-100.

Whidbee, D.A., 1997, Board Composition and Control of Shareholder Voting Rights in the Banking Industry, Financial Management 26, 27-41.

Wurtzebach, C.H., 1988, The Portfolio Construction Process, (Prudential Real Estate Investors, Newark, NJ).

Young, M.S., and R.A. Graff, 1995, Real Estate is Not Normal:A Fresh Look at Real Estate Return Distributions, Journal of Real Estate Finance \& Economics 10, 225-259. 


\section{Data Sources}

Bank for International Settlements

Bloomberg

BVI

Datastream

The European Public Real Estate Association (EPRA)

Jones Lang LaSalle

JP Morgan

Global Property Research (GPR)

The National Association of Real Estate Investment Trusts (NAREIT)

Zephyr 


\section{Exhibits}

Exhibit 1. Growth of the Global Property Share Market

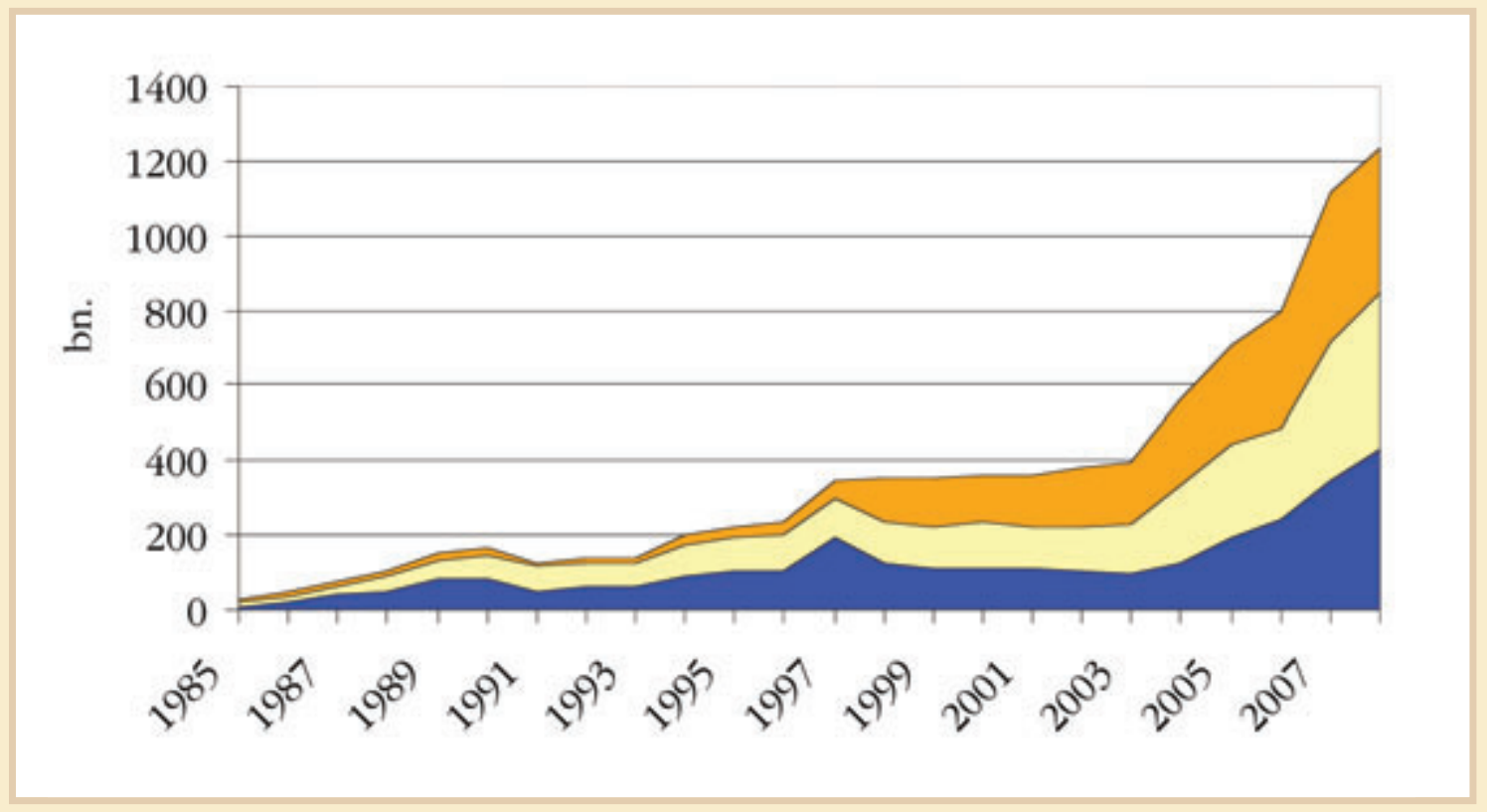

Note: This exhibit shows the growth in market capitalization of the listed property sector in Asia (including Australia), Europe and the Americas for the period January 1985 to June 2007. Numbers are based on the GPR General indices, which include liquid property companies with a minimum market capitalization of US\$50 mln. Companies are only included if at least $75 \%$ of operational turnover is derived from investment activities (property investment companies) or investment and development activities combined (hybrid property companies). Source: GPR. 


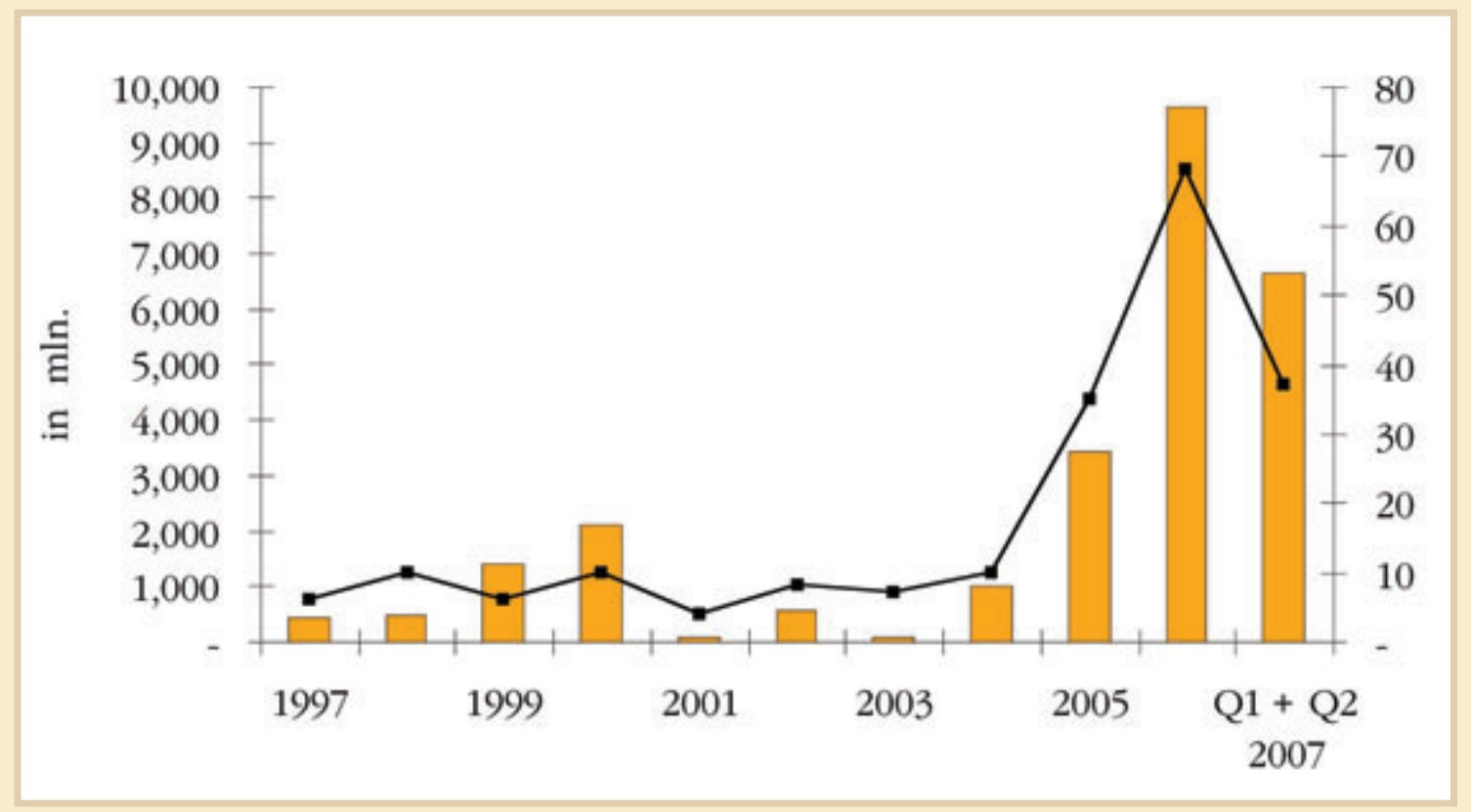

Note: This exhibit provides an overview of Initial Public Offerings of property companies on stock exchanges in Europe for the period January 1997 to June 2007. The bars (left-axis) indicate the total equity raised in millions of euros, whereas the line (right y-axis) indicates the number of IPOs. Source:JP Morgan. 
Exhibit 3. Global Property Share Market: Country Information

\begin{tabular}{|c|c|c|c|c|c|}
\hline Region & Country Name & Tax transparent structure & $\begin{array}{l}\text { Number of } \\
\text { Companies }\end{array}$ & $\begin{array}{l}\text { Listed market } \\
\text { cap (bln.) }\end{array}$ & $\begin{array}{c}9 \% \text { of } \\
\text { total listed } \\
\text { universe }\end{array}$ \\
\hline \multirow[t]{6}{*}{ Americas } & & & 221 & 419.59 & $31.42^{\circ}$ \\
\hline & Argentina & NO & 2 & 0.92 & $0.07 \%$ \\
\hline & Brazil & YES** & 14 & 11.37 & $0.85 \%$ \\
\hline & Canada & YES & 33 & 45.31 & 3.3996 \\
\hline & Chile & YES*- & 1 & 0.47 & $0.0-96$ \\
\hline & us & YES & 171 & 361.51 & $27.07 \%$ \\
\hline \multirow[t]{13}{*}{ Asia } & & & 351 & 527.49 & $39.50 \%$ \\
\hline & China & NO & 79 & 94.41 & $7.07 \%$ \\
\hline & Hong Kong & YES & 67 & 175.24 & 13.1296 \\
\hline & India & UNDER CONSTRUCTION & 6 & 3.74 & $0.28 \%$ \\
\hline & Indonesia & NO & 10 & 3.49 & $0.26 \%$ \\
\hline & Japan & YES & 90 & 163.04 & 12.2196 \\
\hline & Malaysia & YES & 19 & 10.77 & $0.81 \%$ \\
\hline & Philippines & YES & 9 & 8.68 & $0.65 \%$ \\
\hline & Singapore & YES & 37 & 57.26 & 4.2996 \\
\hline & South Korea & YES & 1 & 0.17 & $0.01 \%$ \\
\hline & Taiwan & YES & 20 & 6.58 & 0.4996 \\
\hline & Thailand & YES & 11 & 3.58 & $0.27 \%$ \\
\hline & Vietnam & NO & 2 & 0.53 & $0.0-6 \%$ \\
\hline \multirow[t]{22}{*}{ Europe } & & & 2.15 & 330.92 & 24.789 \\
\hline & Austria & YES* & 11 & 23.71 & $1.78 \%$ \\
\hline & Belgium & YES & 12 & 4.91 & $0.37 \%$ \\
\hline & Channel Islands & YES*** & 7 & 6.45 & $0.48 \%$ \\
\hline & Denmark & NO & 4 & 1.68 & $0.13 \%$ \\
\hline & Finland & UNDER CONSTRUCTION & 3 & 2.66 & $0.20 \%$ \\
\hline & France & YES & 37 & 76.42 & $5.72 \%$ \\
\hline & Germany & YES & 26 & 16.54 & $1.24 \%$ \\
\hline & Greece & YES & 5 & 2.73 & 0.2096 \\
\hline & Hungary & NO & 2 & 0.74 & 0.0696 \\
\hline & Ireland & NO & 2 & 0.87 & $0.06 \%$ \\
\hline & Italy & UNDER CONSTRUCTION** & 11 & 10.58 & 0.7996 \\
\hline & Luxembourg & YES*** & 4 & 5.96 & $0.45 \%$ \\
\hline & Netherlands & YES & 11 & 22.81 & $1.71 \%$ \\
\hline & Norway & NO & 6 & 4.40 & $0.33 \%$ \\
\hline & Poland & YES** & 3 & 4.44 & 0.3396 \\
\hline & Russia & YES** & 3 & 5.44 & 0.4196 \\
\hline & Turkey & YES & 2 & 0.89 & $0.07 \%$ \\
\hline & Spain & YES** & 16 & 36.97 & $2.77 \%$ \\
\hline & Sweden & NO & 16 & 16.17 & $1.21 \%$ \\
\hline & Switzerland & YES* & 6 & 5.20 & $0.39 \%$ \\
\hline & UK & YES & 58 & 81.35 & $6.09 \%$ \\
\hline \multirow[t]{7}{*}{ Middle East } & & & 46 & 48.04 & $3.60 \%$ \\
\hline & Eqypt & NO & 2 & 1.67 & $0.13 \%$ \\
\hline & Isracl & YES & 18 & 11.97 & $0.90 \% 6$ \\
\hline & Kuwait & NO & 16 & 7.18 & $0.54 \%$ \\
\hline & Qatar & NO & 2 & 1.86 & $0.14 \%$ \\
\hline & Saudi Arabia & NO & 3 & 4.66 & 0.3596 \\
\hline & United Arab & YES & 5 & 20.70 & $1.55 \%$ \\
\hline \multirow[t]{3}{*}{ Oceania } & & & 6 & 2.27 & $0.17 \%$ \\
\hline & Australia & YES & 54 & 90.60 & 6.7896 \\
\hline & New Zealand & YES & 6 & 2.27 & $0.17 \%$ \\
\hline \multirow[t]{2}{*}{ Africa } & & & 15 & 7.16 & $0.5 . \%$ \\
\hline & South Africa & YES & 15 & 7.16 & $0.54 \%$ \\
\hline Total & & & 884 & $1,335.47$ & $100.00^{\circ}$ \\
\hline
\end{tabular}

Note: This exhibit provides an overview of the global listed property share market, including all companies with a market capitalization of US\$ 200 million or more, as of June 2007. Sources: Bloomberg, Ernst and Young (2006), Op 't Veld (2007)

* no special REIT legislation, but under the country's open-ended structure, funds do not pay corporate tax

** indicates that there is no special REIT legislation, but the current structure is REIT-like

**** indicates that there is no REIT structure, but beneficial (corporate) tax treatment 


\begin{tabular}{|c|c|c|c|}
\hline Country & Structure name & Year & Full structure name \\
\hline Austria* & ImmoInvFG & 2003 & Immobilien Investmentfondsgesetz \\
\hline Belgium & Sicafi / Bevak & 1995 & Société d'Investissement à Capital Fixe Immobilière \\
\hline Bulgaria & REIT (SPIE) & 2003 & Special Purpose Investment Entity \\
\hline \multicolumn{4}{|l|}{ Cyprus } \\
\hline \multicolumn{4}{|l|}{ Czech Republic } \\
\hline \multicolumn{4}{|l|}{ Denmark } \\
\hline \multicolumn{4}{|l|}{ Estonia } \\
\hline \multicolumn{4}{|l|}{ Finland ${ }^{* * *}$} \\
\hline France & SIIC & 2003 & Société d'Investissements Immobiliers Cotées \\
\hline Germany & G-REIT & 2007 & German Real Estate Investment Trust \\
\hline Greece & REIC & 1999 & Real Estate Investment Company \\
\hline \multicolumn{4}{|l|}{ Hungary } \\
\hline \multicolumn{4}{|l|}{ Ireland } \\
\hline Italy ${ }^{* *} / * * *$ & FII & 1994 & Fondi di Investimento Immobiliare \\
\hline \multicolumn{4}{|l|}{ Latvia } \\
\hline \multicolumn{4}{|l|}{ Lithuana } \\
\hline Luxembourg***** & SICAV & 2002 & Société d'Investissement à Capital Variable \\
\hline Malta** $^{* *}$ & PIF & 1994 & Professional Investor Fund \\
\hline Netherlands & FBI & $1969 / 2007$ & Fiscale Beleggingsinstelling \\
\hline Poland** & REIF & 2004 & Real Estate Investment Fund \\
\hline \multicolumn{4}{|l|}{ Portugal } \\
\hline \multicolumn{4}{|l|}{ Romania } \\
\hline \multicolumn{4}{|l|}{ Slovakia } \\
\hline \multicolumn{4}{|l|}{ Slovenia } \\
\hline Spain** & REIF/REIC & 2003 & Fondos/Sociedades de Inversion Inmobiliaria \\
\hline \multicolumn{4}{|l|}{ Sweden } \\
\hline United Kingdom & UK-REIT & 2007 & UK Real Estate Investment Trust \\
\hline
\end{tabular}

Note: In this exhibit, the different tax-transparent structures in the EU27 countries are listed, including the year of introduction of the structure. Blank boxes indicate that property companies are treated as ordinary corporations. Sources: Ernst and Young (2006), Op 't Veld (2007).

* no special REIT legislation, but under Austria's open-ended structure, funds do not pay corporate tax.

*** no special REIT legislation, but the current structure is REIT-like

**** currently no REIT structure, but steps are undertaken to implement one

****** no REIT structure, but beneficial (corporate) tax treatment 
Exhibit 5. Tax Treatment of Tax-transparent Property Companies in the EU

Country

Austria

Belgium

Bulgaria

France

Germany

Greece

Italy

Luxembourg

Malta

Netherlands

Poland

Spain

United Kingdom

\section{Tax treatment fund}

Tax-exempt

Qualifying property excluded from taxable basis

Capital gains excluded from taxable basis, provided at arm's length

Tax-exempt

Qualifying property excluded from taxable basis

Non-qualifying activities taxed at $33 \%$

$20 \%$ tax on distributions to $10 \%$ or more to exempt/low taxed shareholders

Full exemption CIT and local trade tax

REMF subject to special taxation at $0.3 \%$ on assets

Tax-exempt

Tax-exempt

Annual subscription tax $0.05 \%$ of total assets ( $0.01 \%$ or $0 \%$ for institutional investors)

Tax-exempt

CIT rate $0 \%$ so non tax-exempt structure

Capital gains not taxed provided they are added to tax-exempt reinvestment base

Tax-exempt

CIT rate $1 \%$ of net income, but no entitlement to any deduction

Not a flow-through entity for Spanish investors

Transfer tax: rebate of $95 \%$ for housing purchased for subleasing

Capital gains tax exempt

Tax on development if sold within 3 years

Tax on distributions to corporate shareholdings $>10 \%$

Note: This exhibit shows the differences in tax treatments that apply to property companies acting under a REIT-like regime in Europe. A blank box indicates that no restrictions apply. Sources: Ernst and Young (2006), Op 't Veld (2007). 


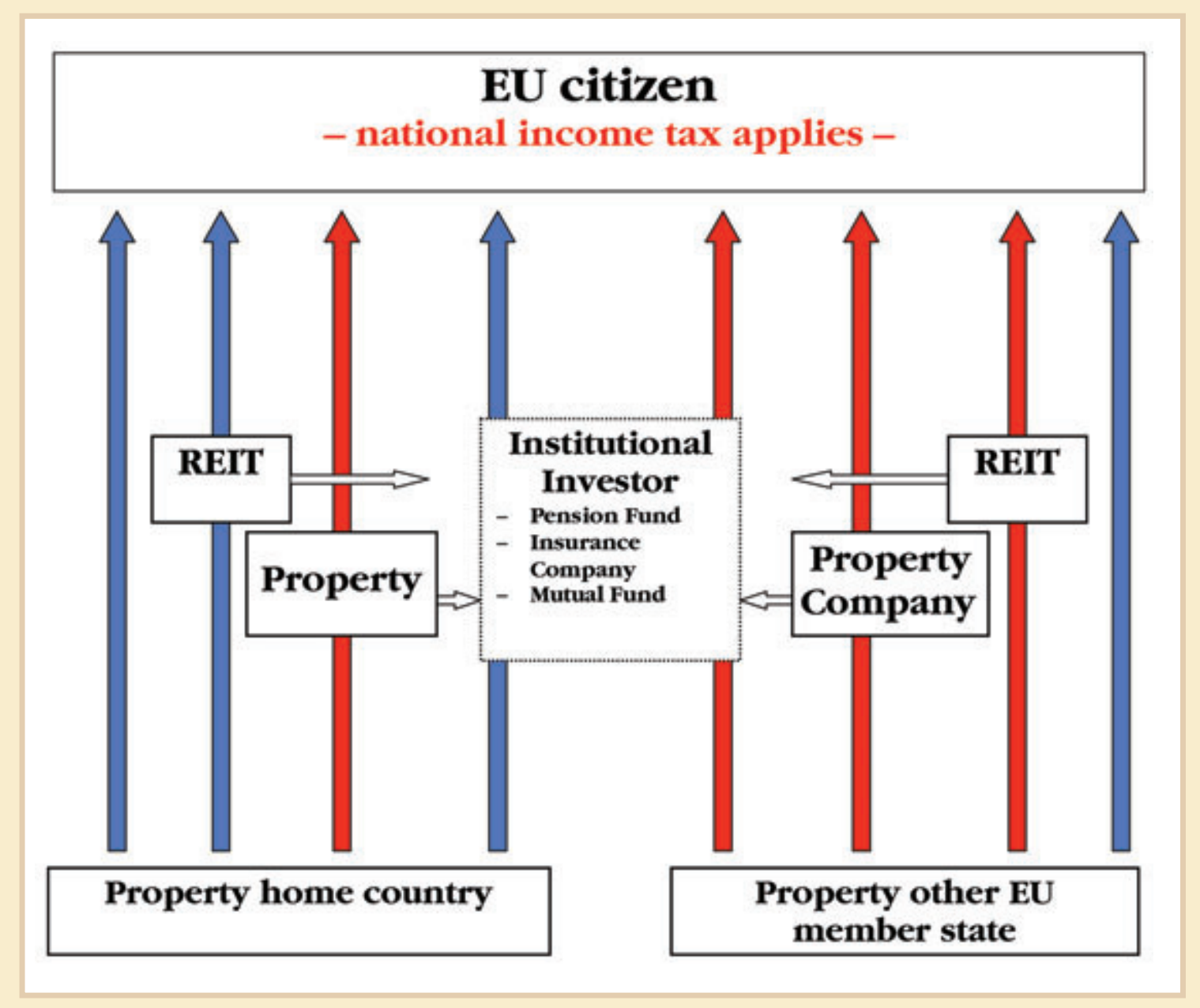

Note: This exhibit provides an overview of the cash flows stemming from a property investment, under the various alternative investment methods available to an EU citizen. REITs are tax-exempt, and property companies are not. We only regard REITs and property companies in the end-investor's home country.A red arrow indicates that the particular cash flow is taxed, while a blue arrow indicates that the cash flow is tax exempt. 
Country

Austria

Belgium

Bulgaria

France

Germany

Greece

Italy

Luxembourg

Malta

Netherlands

Spain

United Kingdom $\quad>90 \%$ of income profits on property rental business No obligation to distribute capital gains

Note: In this exhibit we show the distribution requirements under the different REIT-like regimes in Europe. A blank box indicates that no restrictions apply. Sources: Ernst and Young (2006), Op 't Veld (2007). 


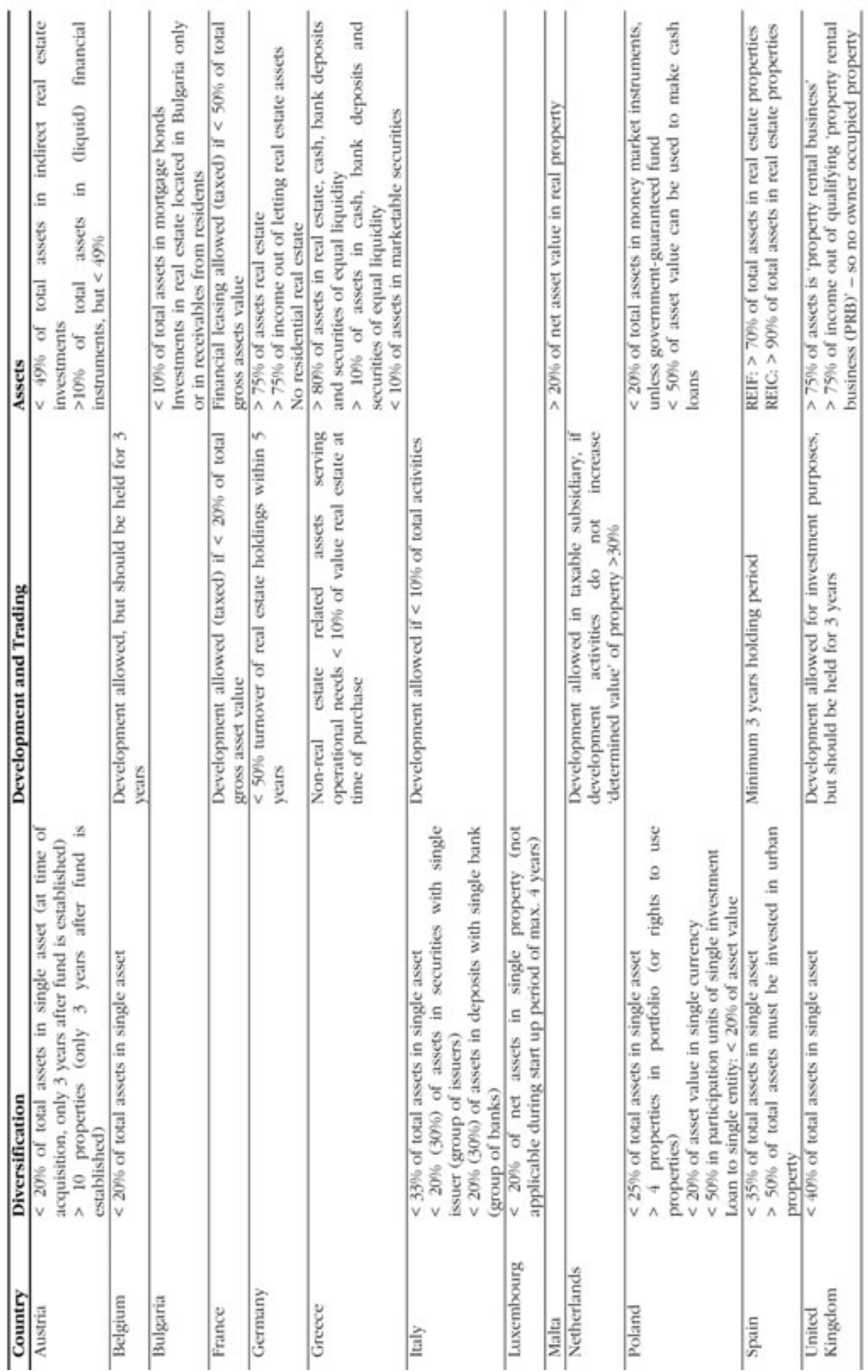

Notes: This exhibit shows the operational restrictions under the different REIT-like regimes in Europe. We distinguish restrictions on diversification of assets, restriction on development and restrictions on the type assets. Blank boxes indicate that no restrictions apply. Sources: Ernst and Young (2006), Op 't Veld (2007). 
Exhibit 9. Leverage restrictions for Tax-transparent Property Companies in the EU

\begin{tabular}{|c|c|}
\hline Country & Gearing limit \\
\hline Austria & $<40 \%$ of total assets \\
\hline Belgium & $\begin{array}{l}<50 \% \text { of total assets } \\
<80 \% \text { of total income to annual interest costs }\end{array}$ \\
\hline Bulgaria & N/A \\
\hline France & Unlimited, but thin capitalization rules apply \\
\hline Germany & $<60 \%$ of Net Asset Value \\
\hline Greece & $<25 \%$ of total real estate investment \\
\hline Italy & $\begin{array}{l}<60 \% \text { of value real property } \\
<20 \% \text { of value other investments }\end{array}$ \\
\hline Luxembourg & $\begin{array}{l}<50 \% \text { of market value all properties, but an increase to } 70 \% \text { might be granted } \\
\text { by government }\end{array}$ \\
\hline Malta & $\begin{array}{l}\text { 'Experienced investors': no leverage } \\
\text { 'Qualifying investors': }<50 \% \text { of total assets }\end{array}$ \\
\hline Netherlands & $\begin{array}{l}<60 \% \text { of total tax book value of real property } \\
<20 \% \text { of total tax book value other investments }\end{array}$ \\
\hline Poland & $\begin{array}{l}<75 \% \text { of total asset value from credits } \\
<20 \% \text { of total asset value from bonds }\end{array}$ \\
\hline Spain & $<10 \%$ of total assets from external financing (REIC) \\
\hline United Kingdom & $\begin{array}{l}\text { Unlimited } \\
\text { If property rental profits/financing cost-ratio }<1.25 \text { than tax charge applies on } \\
\text { excess financing costs }\end{array}$ \\
\hline
\end{tabular}

Note: This exhibit shows the leverage restrictions that apply under the different REIT-like structures in the EU. N/A means no information available. Sources: Ernst and Young (2006), Op 't Veld (2007). 


\section{Country}

Austria

Belgium

Bulgaria

Greece

Italy

Luxembourg

tion

Malta

Netherlands

Poland

Spain

$>100$ shareholders

United Kingdom

insufficient liquidity

Mandatory listing

Mandatory listing

Mandatory listing

Mandatory listing

Mandatory listing

\section{Shareholder requirements}

Fund units are publicly offered but not traded (open-end structure)

Fund units redeemable at any time, but special rules apply in case of

Option for 'special fund' for institutional investors ( $>10$ investors)

$<30 \%$ of shares with voting rights must be offered to the public within one year following incorporation

$>30 \%$ of shares must be subscribed by institutional investors

$<50$ persons/entities can be founders of SPIE

Listing should increase capital by at least $30 \%$

Individual or affiliated holding $<60 \%$

Upon selection: $15 \%$ of shares owned by investors with max. $2 \%$ interest

Individual holding $<10 \%$ voting rights

$>15 \%$ of shares owned by investors that hold $<3 \%$ voting rights

Minimum equity size $\Leftrightarrow 1.25 \mathrm{~mm}$. to be raised during six months after incorpora-

Minimum initial threshold 'experienced investor': USD20,000

Minimum initial threshold 'qualifying investor': USD100,000

Note: This exhibit shows the shareholder requirements that apply to property companies acting under a REIT-like regime in Europe.A blank box indicates that no restrictions apply. Sources: Ernst and Young (2006), Op 't Veld (2007). 
Country

Austria

Belgium

Bulgaria

France

Germany

Greece

Italy

Luxembourg

Malta

Netherlands

Poland

Spain

United Kingdom

\section{Withholding tax treatment}

$25 \%$ withholding tax on profits, distributed and undistributed Fictitious distributions of retained profits are taxed at unit holder level $80 \%$ of increase in value of the real estate, even if not realized, is taxed

Foreign investors: $15 \%$ withholding tax, but might be reduced pursuant to tax treaties

7\% withholding tax on dividends, but might be reduced pursuant to tax treaties

Foreign investors: $25 \%$ withholding tax, but might be reduced pursuant to tax treaties (if EU corporate shareholder $>25 \%$ of shares, tax-exemption does not apply)

Domestic and foreign investors: $15 \%$ withholding tax (some countries 10\%)

Foreign investors: $20 \%$ withholding tax, income tax treaties do not reduce rate of withholding

Foreign investors: $12.5 \%$ withholding tax, which may be reduced to $0 \%$ in case of distribution to qualified resident or non-resident unit holders

Domestic and foreign investors: $15 \%$ withholding tax

EU tax-exempt shareholders: full refund

Capital gains distribution: not taxed

$19 \%$ withholding tax on dividend income

$19 \%$ tax at investor level on capital gains

Foreign investors: $15 \%$ withholding tax on dividend income, but might be reduced pursuant to tax treaties

Foreign investors: $35 \%$ withholding tax in capital gains distribution, but might be reduced pursuant to tax treaties

$22 \%$ withholding tax

Note: This exhibit shows the withholding tax that is applied under different REIT-like regimes in Europe.A blank box indicates that no restrictions apply. Sources: Ernst and Young (2006), Op 't Veld (2007). 
Exhibit 12. Diversification by European Property Companies

\begin{tabular}{lcc}
\hline & \# of firms & $\%$ of sample \\
\hline A. Intemational diusification & 34 & \\
International & 90 & $77.2 \%$ \\
National & & \\
& & \\
B. Sectord diursification & 33 & $26.6 \%$ \\
1 sector & 48 & $38.7 \%$ \\
2 sectors & 37 & $29.8 \%$ \\
3 sectors & 6 & $4.8 \%$ \\
4 or more sectors & & \\
& & \\
C. Pryperytype & 88 & $71.0 \%$ \\
Office & 71 & $57.3 \%$ \\
Retail & 36 & $29.0 \%$ \\
Industry & 25 & $20.2 \%$ \\
Residential & 7 & $5.6 \%$ \\
Hotel & 38 & $30.6 \%$ \\
Other & & \\
& 124 & $100 \%$ \\
\hline Total number of firms in sample &
\end{tabular}

Note: In this exhibit, the diversification of investments of all EU property companies with market capitalization larger than $€ 50$ million is presented. In Panel A, property companies are classified as national if more than $75 \%$ of total investments are in a single country. Panel B shows the absolute number and proportion of the sample that invest in 1,2,3 or more sectors, with a minimum investment of $10 \%$ in a specific sector. Panel $\mathrm{C}$ shows the absolute number and proportion of the sample that invest in different property types, with a minimum investment of $10 \%$ in a specific sector.All numbers are based on the GPR General Europe sample. Source: GPR 
Exhibit 13. Investments in Different Property Types: United States versus Europe

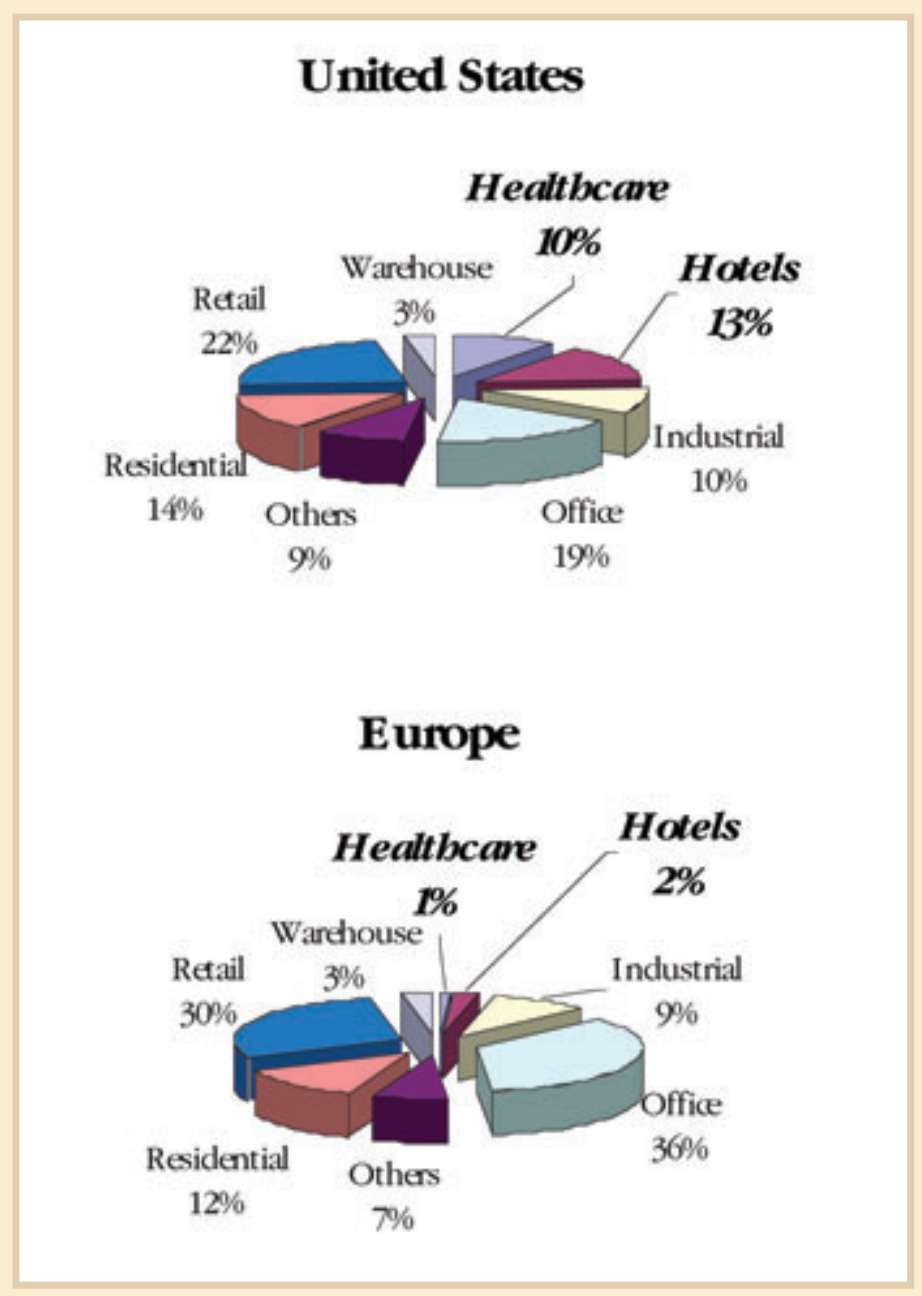

Note: This exhibit shows the proportion of investments in different property types as of June 2007. Sources: GPR and NAREIT. 
Exhibit 14. Corporate Focus of Property Companies in Europe and the United States

\begin{tabular}{|c|c|c|c|}
\hline & Europe & United States & \\
\hline Geograpbiad Foas & & & $t$-stat \\
\hline Mean Herfindahl & 0.84 & 0.42 & $(12.95)^{* * *}$ \\
\hline Mean $\#$ of Regions & 2.12 & 5.23 & \\
\hline Sedord Foas & & & $t$-stat \\
\hline Mean Herfindahl & 0.60 & 0.82 & $(7.51)^{* *}$ \\
\hline Mean $\#$ of Sectors & 3.21 & 2.98 & \\
\hline Number of companies & 124 & 132 & \\
\hline
\end{tabular}

Note: Exhibit 14 shows the degree of diversification for a sample of European and American property companies. The Herfindahl index is calculated for each individual property company as the sum of squared sector or region weights.A Herfindahl index close to one indicates that a property company is focused, as opposed to a Herfindahl index close to zero, which indicates diversification. To assess whether average Herfindahl indices differ statistically between the United States and Europe, we perform an independent sample t-test, assuming unequal variances. Sources: GPR, NAREIT, authors' calculations.

** denotes significance at the $1 \%$ level 
Exhibit 15. Diversification and Performance; Regression Results

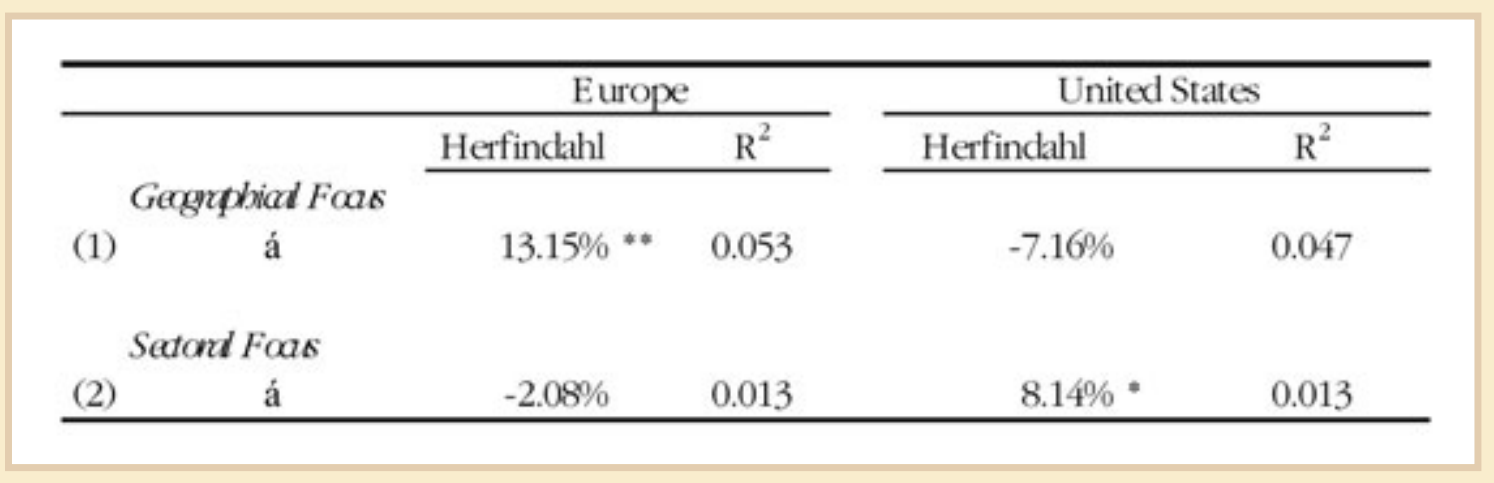

Note: Exhibit 15 presents the results of the ordinary least squares (OLS) regression in which we test the relation between Jensen alpha and (1) geographic focus and (2) sector focus. The coefficients are annualized percentages. The $\mathrm{R}^{2}$ indicate the fit of the model, and varies between one (perfect fit) and zero (no fit). In the models, we control for size, leverage and dividend yield, but coefficients are not reported. Sources: GPR, NAREIT, authors' calculations.

*** denotes significance at the $5 \%$ level

* denotes significance at the $10 \%$ level 
Exhibit 16. International Correlation Matrices within Asset Classes

\begin{tabular}{|c|c|c|c|c|c|c|c|c|c|c|c|}
\hline \multicolumn{12}{|c|}{ Property shore inderess } \\
\hline & $\mathrm{AU}$ & FR & DE & NL & SP & $5 w$ & $\mathrm{CH}$ & IK & JA & SI & CA \\
\hline France & 0.41 & & & & & & & & & & \\
\hline Gumany & 0.29 & 0.45 & & & & & & & & & \\
\hline Nethertank & 0.30 & 086 & 0.35 & & & & & & & & \\
\hline Spin & 0.30 & $0+4$ & 0.15 & 0.20 & & & & & & & \\
\hline Smolin & 0.16 & Q.48 & 0.29 & 0.43 & 023 & & & & & & \\
\hline Suitcerlend & 0.20 & Qis & 0.29 & 0.36 & a.17 & 0.25 & & & & & \\
\hline Unad Kingiom & 0.24 & 042 & 0.38 & $0+4$ & a.15 & 036 & 0.17 & & & & \\
\hline Japn & a.1 & 0.17 & 029 & 0.18 & 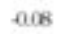 & 0.15 & 0.10 & ats & & & \\
\hline Singrere & 0.12 & 0.25 & 0.18 & Q99) & 0.20 & 032 & 0.13 & a.9 & $0.2)$ & & \\
\hline Condr & 0.18 & 0.21 & 0.13 & a.7 & 0.21 & 0.21 & 0.21 & $\alpha 20$ & 0.22 & 0.22 & \\
\hline Unibal Setes & 0.19 & 033 & 0.21 & 0.34 & 024 & 032 & 0.22 & 0.36 & 0.05 & 034 & $a w$ \\
\hline \multicolumn{12}{|c|}{ Common Seckindeves } \\
\hline & $\mathrm{AU}$ & FR & $\mathrm{DE}$ & NL. & $S$ & $5 \mathrm{w}$ & $\mathrm{OH}$ & UK & JA & st & $\mathrm{CA}$ \\
\hline Prane & 0.59 & & & & & & & & & & \\
\hline Gurmay & ast & a.so & & & & & & & & & \\
\hline Nethering & 0.65 & 090 & 0.76 & & & & & & & & \\
\hline Spin & $0.6 i$ & $a>$ & 067 & $a x$ & & & & & & & \\
\hline Smatin & 0.52 & 0.86 & 0.79 & 0.82 & 072 & & & & & & \\
\hline Saitarland & 0.66 & osi & 0.71 & 085 & o.81 & 0.73 & & & & & \\
\hline Unibul Kirgabm & 0.68 & os3 & 0.76 & 0.86 & $a>y$ & 0.76 & ose & & & & \\
\hline Jan & 037 & Qso & 0.60 & 0.6 & 0.43 & 0.50 & 0.8 & Q45 & & & \\
\hline Sinepre & 0.53 & 047 & $0 .+4$ & 0.50 & a46 & 0.48 & 0.48 & 056 & 0.39 & & \\
\hline Conch & 0.61 & $\alpha 6$ & 0.72 & 0.66 & 059 & 0.70 & 0.64 & $a 71$ & $0 .+1$ & 0.58 & \\
\hline Unbat Seas & 0.53 & an & 0.75 & 0.76 & 0.70 & 0.75 & 075 & Q.80 & 0.48 & 0.98 & $\alpha>2$ \\
\hline \multicolumn{12}{|l|}{ Band Inderess } \\
\hline & $\mathrm{AU}$ & $\mathrm{FR}$ & DE & NL. & $\mathbf{S P}$ & $S w$ & 애 & IK & IA & st & $\mathrm{CA}$ \\
\hline Frno & $09_{0}$ & & & & & & & & & & \\
\hline Guminy & 099 & 0.95 & & & & & & & & & \\
\hline Nethertank. & 0.95 & 096 & 0.95 & & & & & & & & \\
\hline Spin & 083 & 0.88 & 082 & 0.88 & & & & & & & \\
\hline Smaln & 0.33 & 0,37 & 0.31 & 037 & 045 & & & & & & \\
\hline Saicarlond & 0.50 & 045 & 0.50 & 0.42 & 0.33 & 0.10 & & & & & \\
\hline Unind Kingdm & 074 & $\alpha \pi$ & 0.76 & $\alpha \lambda$ & $a \rightarrow 7$ & 035 & 0.33 & & & & \\
\hline Jann & 0.16 & 0.12 & 0.14 & 0.19 & 008 & 0.01 & 0.11 & 008 & & & \\
\hline Singpre & 0.51 & 0.46 & 0.50 & 0.7 & 0.37 & 0.21 & 036 & 0.33 & 0.25 & & \\
\hline Candh & 0.66 & 0.88 & 0.66 & 071 & 0.66 & 0.23 & 0.26 & 0.67 & 0.22 & $0+1$ & \\
\hline Unind Setos & 0.74 & 0.75 & 0.75 & 0.77 & 0.68 & 0.25 & 0.36 & 0.70 & 0.19 & 0.56 & $0 \times 0$ \\
\hline
\end{tabular}

Note: This exhibit provides correlations between national capital markets by asset class: property shares, stocks, and bonds. All indices are from January 1995 to December 2006, and are based on logarithmic total returns in local currency. Sources: GPR, Datastream, authors' calculations. 
Exhibit 17. The Effect of REIT Introduction on Leverage

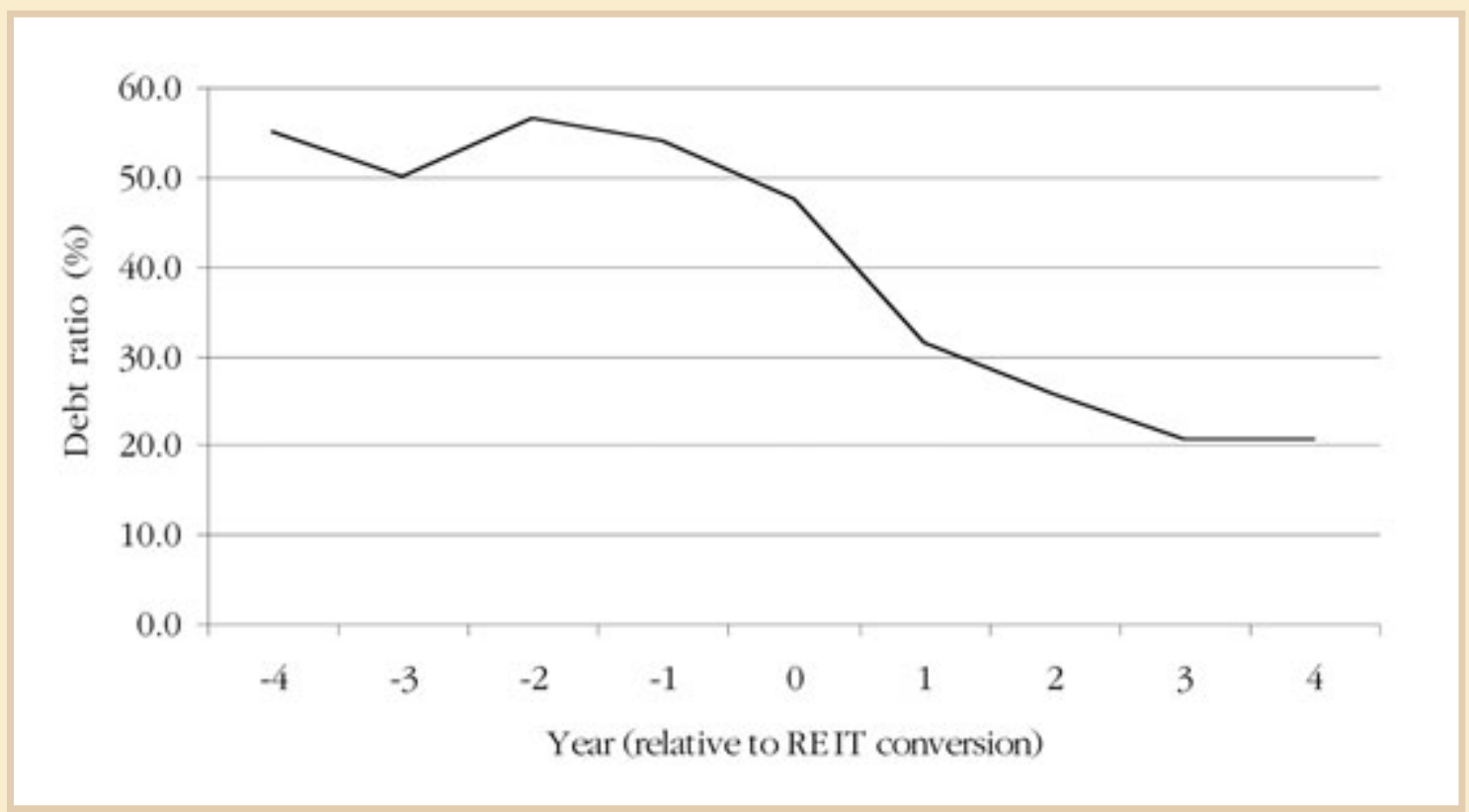

Note: This exhibit shows the average debt ratio for a sample of property funds in the four years before the adoption of the REIT structure and the four years after adoption of the REIT structure. The debt ratio is calculated by dividing total debt (in local currency) by total assets (in local currency). We construct the sample with property companies from Belgium, Canada and France. 
Exhibit 18. International Correlation across Housing Markets

\begin{tabular}{lcccccccc}
\hline & AU & FR & NL & SP & SW & CH & UK & CA \\
\hline France & 0.18 & & & & & & & \\
Netherlands & -0.10 & 0.32 & & & & & & \\
Spain & 0.23 & 0.50 & -0.11 & & & & & \\
Sweden & 0.03 & 0.65 & 0.39 & 0.44 & & & & \\
Switzerland & 0.41 & 0.49 & -0.04 & 0.43 & 0.38 & & & \\
United Kingdom & 0.30 & 0.49 & 0.43 & 0.30 & 0.55 & 0.34 & & \\
Canada & 0.34 & 0.20 & -0.23 & 0.48 & 0.10 & 0.25 & -0.01 & \\
United States & -0.09 & 0.42 & -0.12 & 0.24 & 0.29 & 0.34 & 0.05 & 0.12 \\
\hline
\end{tabular}

Note: This exhibit provides correlations between national housing markets. Indices are from January 1980 to December 2006, and are based on logarithmic quarterly returns in local currency. Source: BIS, authors' calculations. 
Exhibit 19. Example of a Corporate Structure to Avoid Corporate Taxation

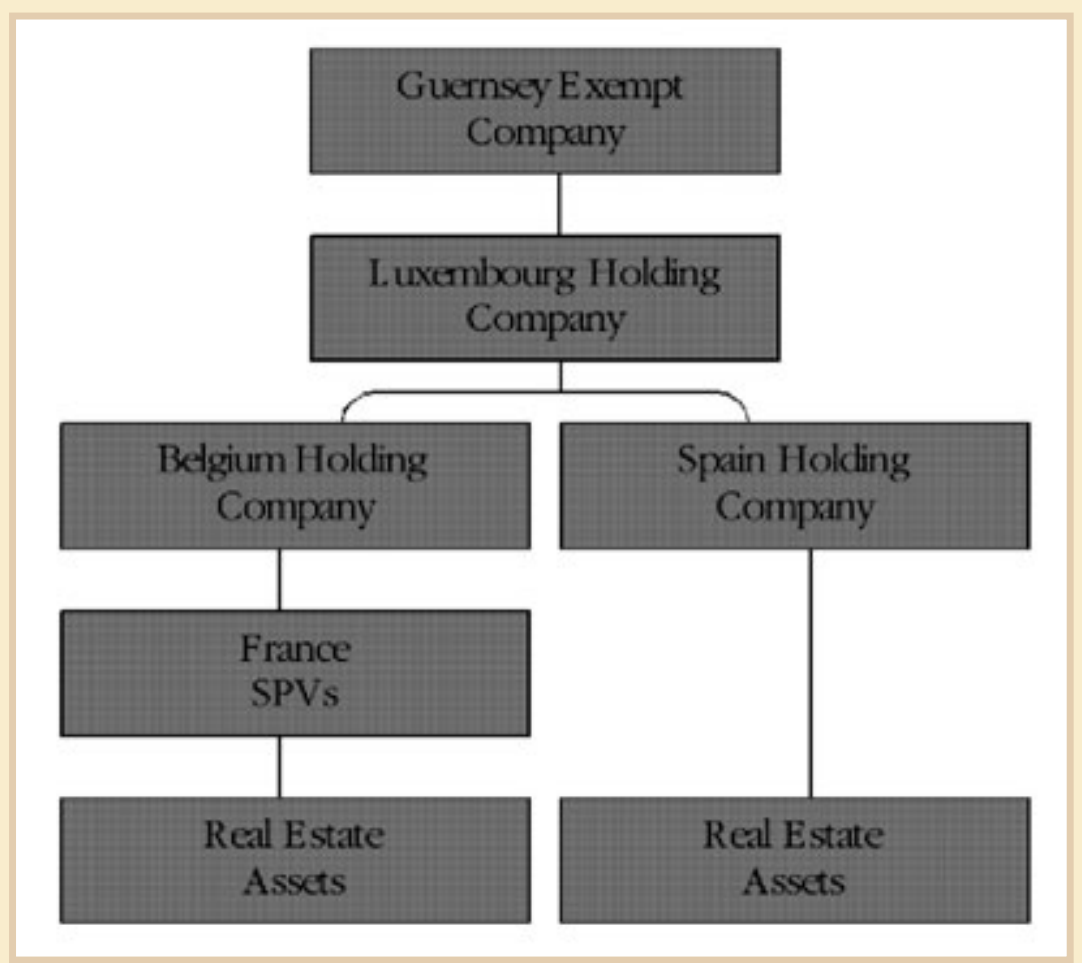

Note: This exhibit shows a possible corporate structure for a property company that enables the parent company to avoid both local taxes on rental income and withholding taxes on profit repatriation. 
Exhibit 20. Initial Public Offerings of Property Companies on European Stock Exchanges

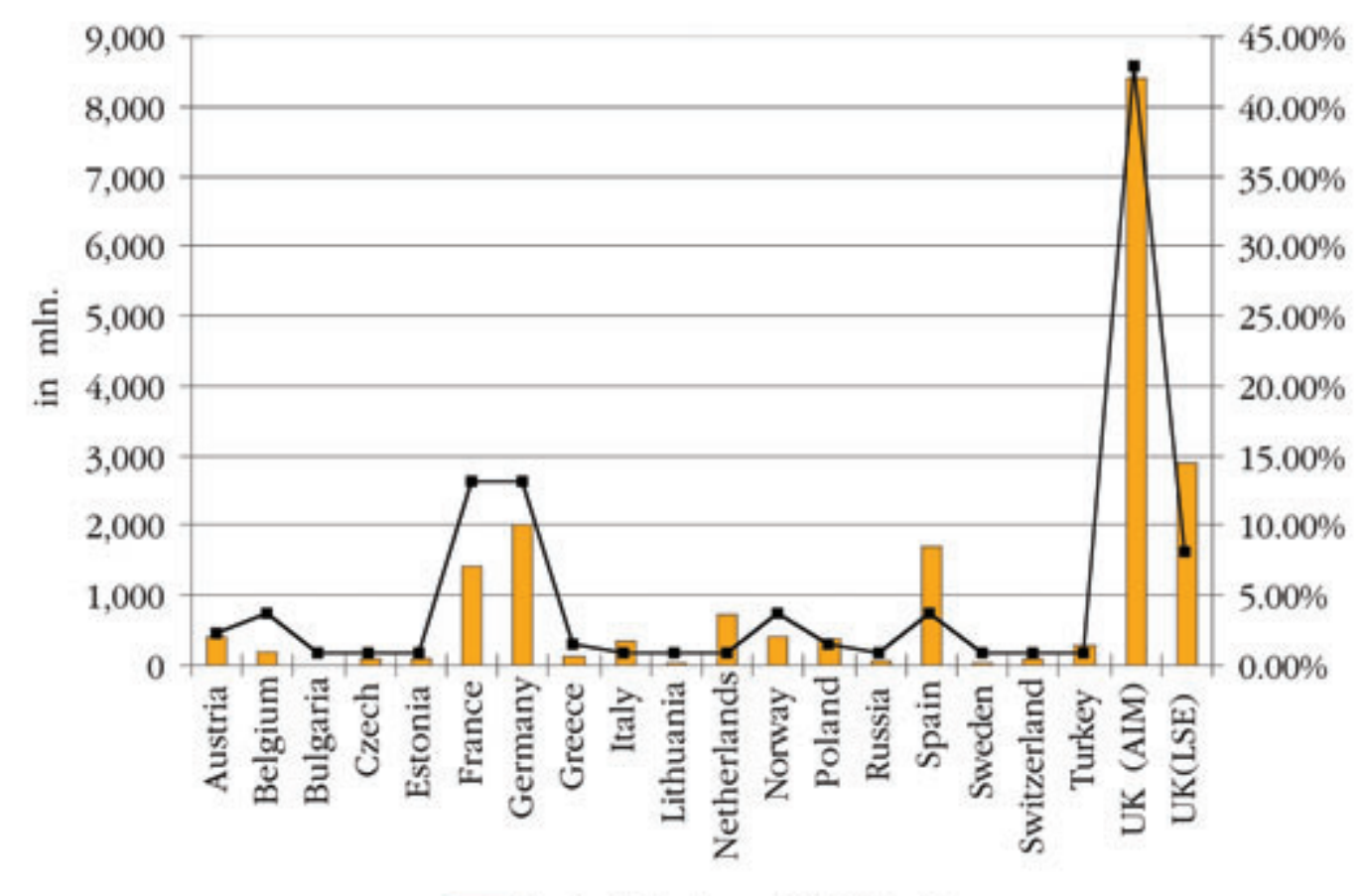

Equity Raised $\rightarrow \%$ Of Deals

Note: This exhibit shows the number of IPOs (left axis) on the different European stock exchanges and the total equity raised (right axis), for the period from January 2005 to June 2007. Source: JP Morgan. 
Exhibit 21. Initial Public Offerings of Property Companies through Tax Havens

\begin{tabular}{|c|c|c|c|c|}
\hline & $\begin{array}{l}\text { Number of } \\
\text { IPOs }\end{array}$ & $\begin{array}{l}\% \text { Total } \\
\text { IPOS }\end{array}$ & $\begin{array}{l}\text { Equity Raised } \\
\text { in bln. }\end{array}$ & $\begin{array}{c}\% \text { Total } \\
\text { Equity Raised }\end{array}$ \\
\hline \multicolumn{5}{|c|}{ Pand A. IPOs pertax haw } \\
\hline Bermuda & 1 & $0.71 \%$ & 43.21 & $0.31 \%$ \\
\hline Cyprus & 3 & $2.14 \%$ & 319.95 & $2.29 \%$ \\
\hline Guernsey & 18 & $12.86 \%$ & $2,894.05$ & $20.70 \%$ \\
\hline Jersey & 5 & $3.57 \%$ & 755.89 & $5.41 \%$ \\
\hline Isle-of-Man & 11 & $7.86 \%$ & $1,846.57$ & $13.21 \%$ \\
\hline Virgin Islands & 3 & $2.14 \%$ & 243.97 & $1.74 \%$ \\
\hline \multicolumn{5}{|c|}{ Pand B. Tax HaunIPOs aur sanpleperiod } \\
\hline Q1 2005 & 1 & $16.67 \%$ & 71.58 & $29.68 \%$ \\
\hline Q2 2005 & 2 & $22.22 \%$ & 62.70 & $13.31 \%$ \\
\hline Q3 2005 & 4 & $100.00 \%$ & 460.93 & $100.00 \%$ \\
\hline Q4 2005 & 6 & $37.50 \%$ & $1,571.25$ & $68.84 \%$ \\
\hline Q1 2006 & 7 & $58.33 \%$ & 963.63 & $62.29 \%$ \\
\hline Q2 2006 & 5 & $31.25 \%$ & 771.19 & $31.63 \%$ \\
\hline Q3 2006 & 1 & $11.11 \%$ & 100.00 & $7.43 \%$ \\
\hline Q4 2006 & 6 & $20.00 \%$ & 960.55 & $22.25 \%$ \\
\hline Q1 2007 & 3 & $17.65 \%$ & 307.00 & $33.92 \%$ \\
\hline Q2 2007 & 6 & $30.00 \%$ & 834.82 & $14.55 \%$ \\
\hline$T d d$ & 41 & $29.29 \%$ & 6103.63 & $43.65 \%$ \\
\hline
\end{tabular}

Note: This exhibit shows in Panel A: (1) the number of IPOs of companies incorporated in tax havens, (2) the percentage of these IPOs as a share of the total number of IPOs in Europe, (3) the equity raised by IPOs of companies incorporated in tax havens, and (4) the percentage of equity raised by property companies incorporated in tax havens as a share of total equity raised with IPOs of property companies. The time period is January 2005 through June 2007. In Panel B, IPOs through tax havens are sorted by quarter. Source: Zephyr. 
Exhibit 22. Initial Public Offerings of Property Companies on the AIM

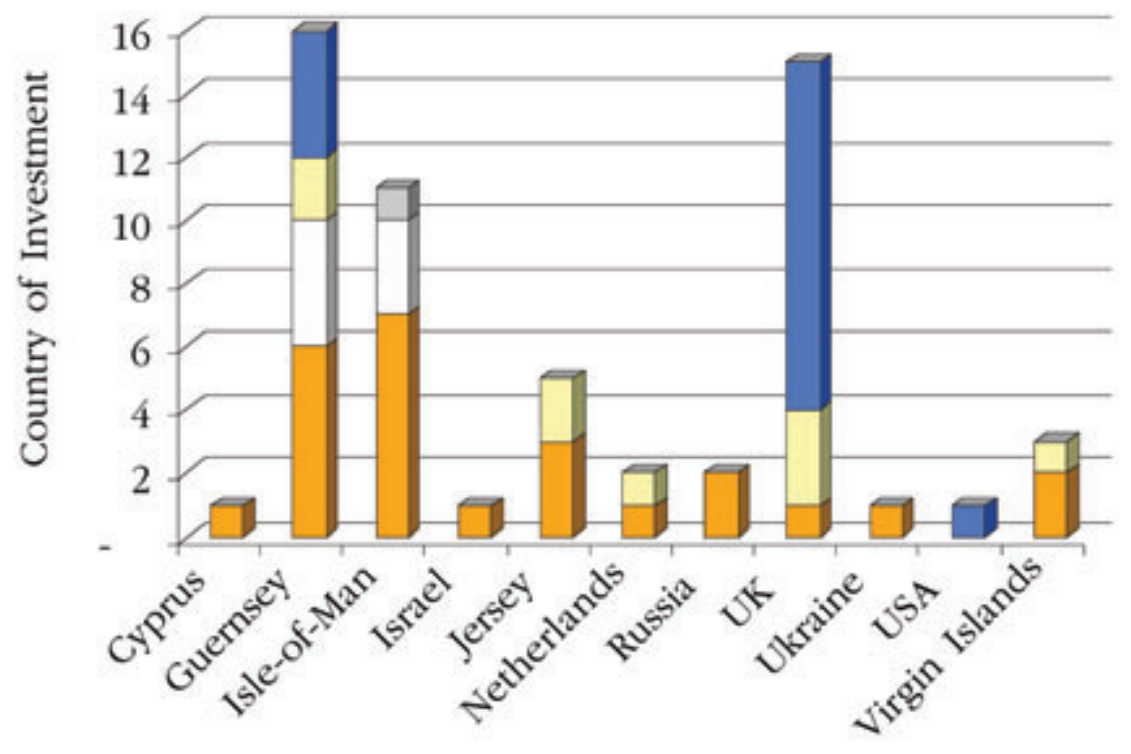

Country of Incorporation

Eastern E urope $\square$ Germany $\square$ E urope (Diversified) $\square$ UK $\square$ Asia

Note: This exhibit provides the details of all 59 property company listings on the Alternative Investment Market (AIM) in London.The $\mathrm{x}$-axis shows the country where the IPO is incorporated, whereas the y-axis shows the number of IPOs, and the bar colours display the regional investment focus of the property companies per country of incorporation. Source: Zephyr. 
Exhibit 23. Rodamco's Stock Performance During Open- and Closed-ended Regime

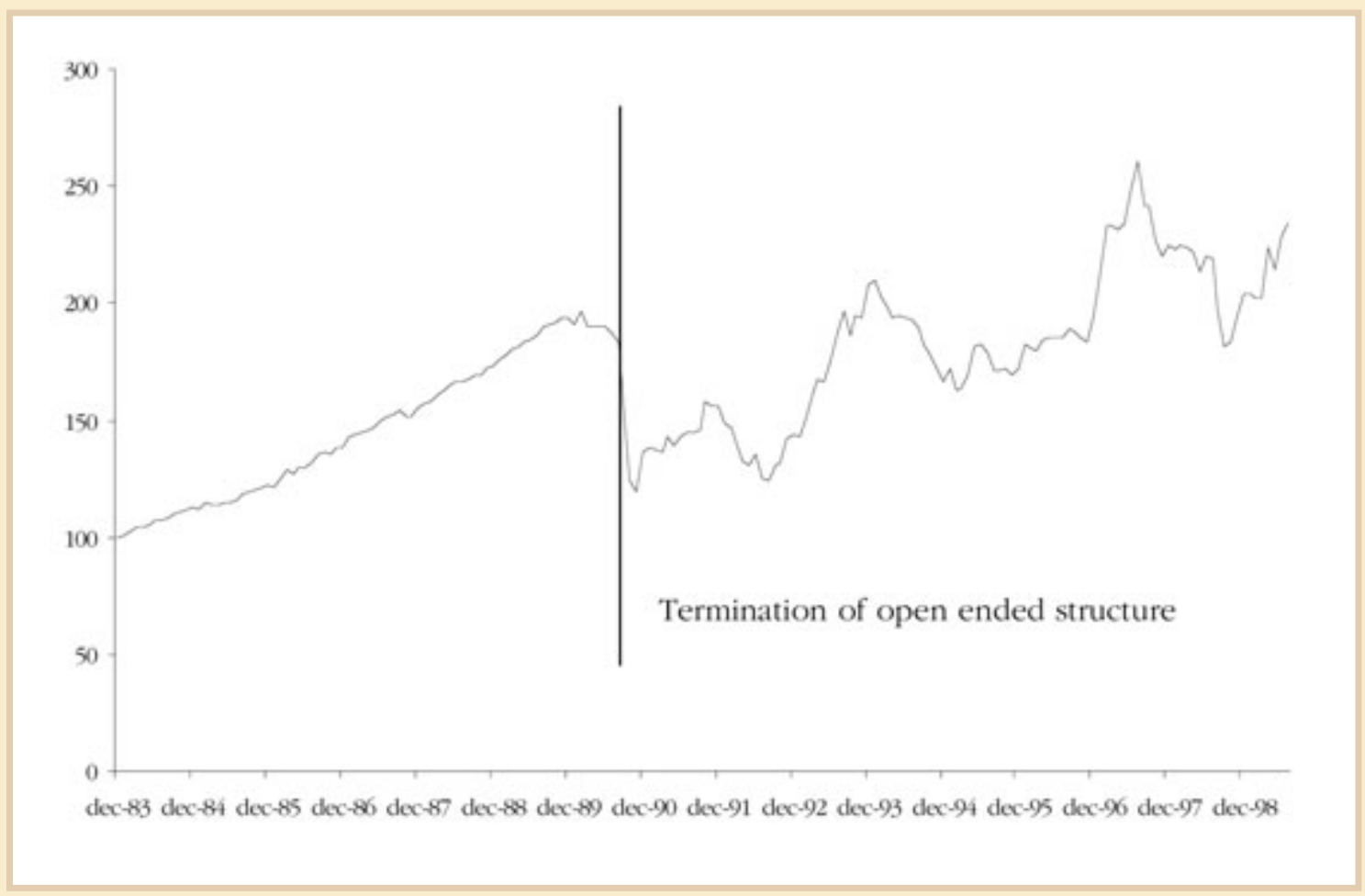

Note: This exhibit provides a graph of the total return on the shares of Rodamco, i.e. stock price history is combined with reinvested dividends. The period investigated runs from December 1983 until September 1999. Source: GPR 
Exhibit 24. Portfolio Composition of German Open-ended Funds

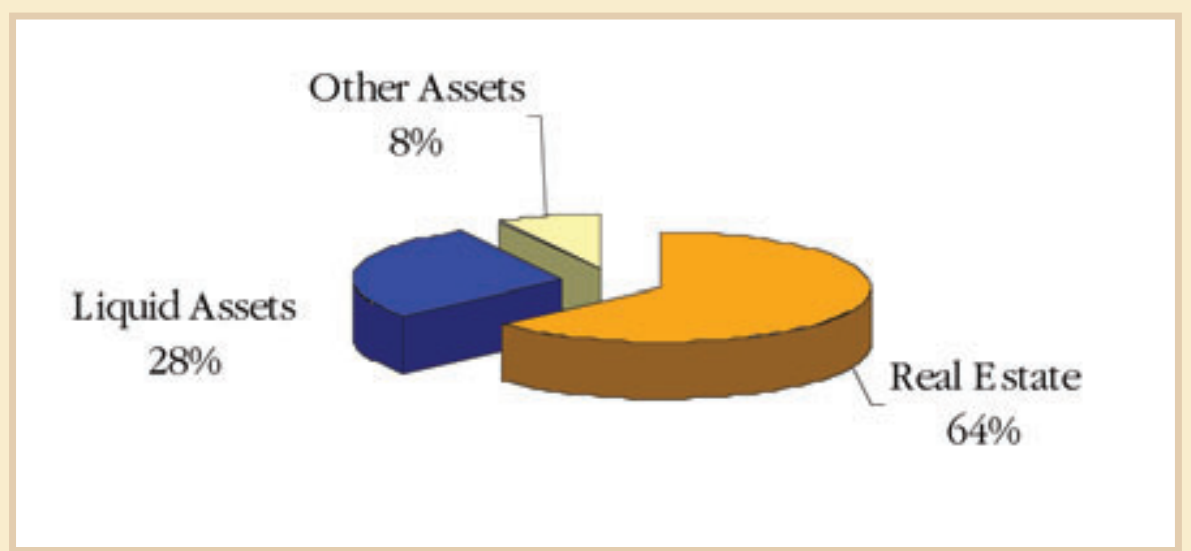

Note: This exhibit shows the asset composition for a sample of German open-end property funds at June 2007. Source: BVI. 
Exhibit 25. Performance of German Open-ended Funds

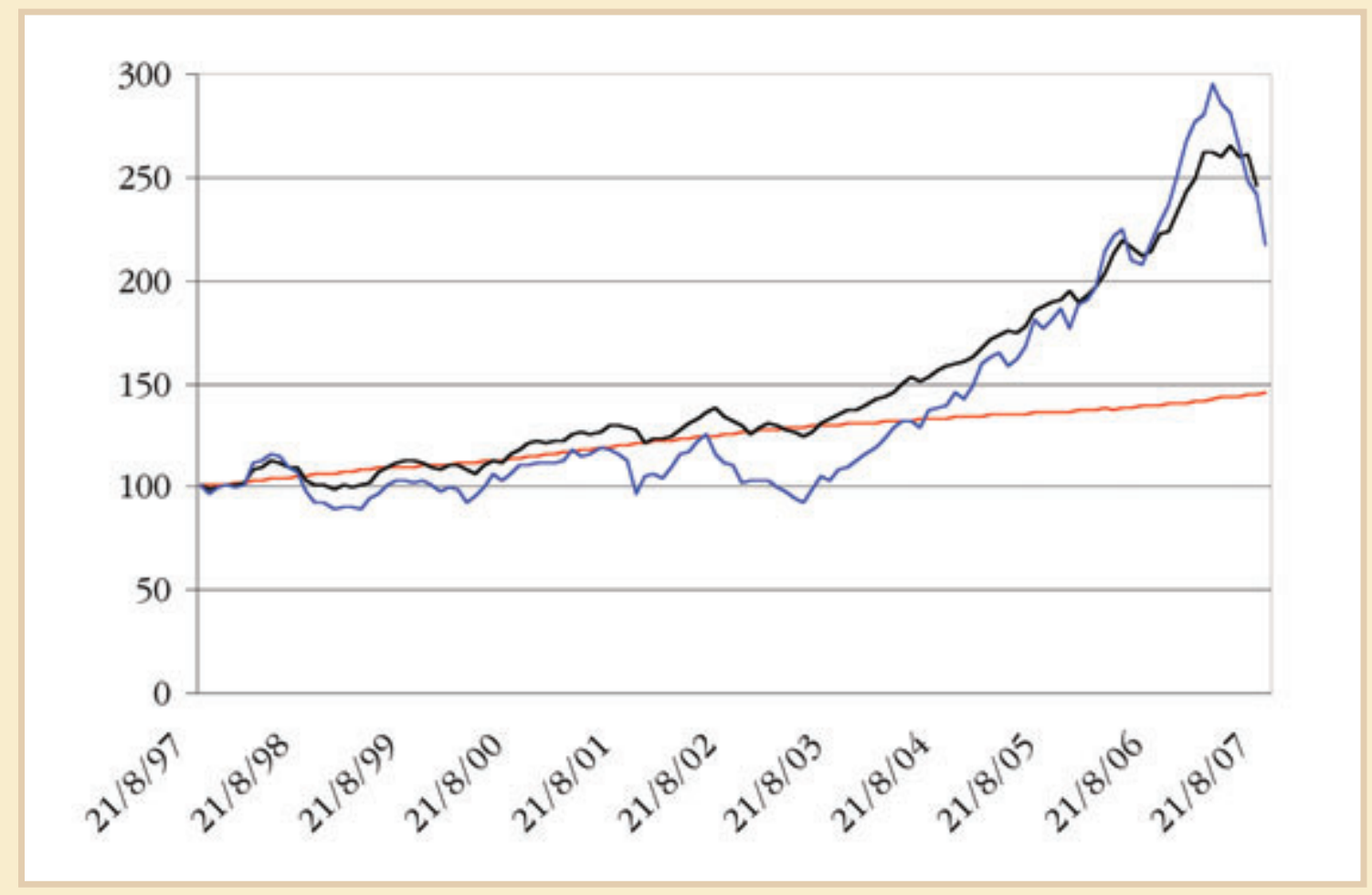

Note: This exhibit compares the average total return performance of the cross section of German openended property funds to two commonly used European property share indices: the GPR General Europe and the GPR 250 Europe. Sources: Datastream, GPR 


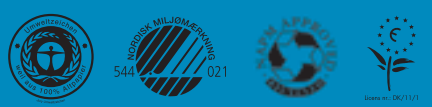

